\title{
Morphology, structure, composition and build-up processes of the active channel-mouth lobe complex of the Congo deep-sea fan with inputs from remotely operated underwater vehicle (ROV) multibeam and video surveys
}

\author{
Dennielou Bernard ${ }^{1,}{ }^{*}$, Droz Laurence ${ }^{2}$, Babonneau Nathalie ${ }^{2}$, Jacq Celine ${ }^{1,2}$, Bonnel Cedric ${ }^{1,3}$, \\ Picot Marie 1, 2, Le Saout Morgane ${ }^{1}$, Saout Yohan ${ }^{1}$, Bez Martine ${ }^{4}$, Savoye Bruno ${ }^{1}$, Olu Karine ${ }^{5}$, \\ Rabouille Christophe 5,6
}

${ }^{1}$ IFREMER, Ctr Brest, Unite Rech Geosci Marines, F-29280 Plouzane, France.

2 Univ Brest, UMR Geosci Ocean 6538, UBO, Inst Univ Europeen Mer, PI Copernic, F-29280 Plouzane, France.

3 Univ Pau \& Pays Adour, UMR 5150, Lab Fluides Complexes \& Leurs Reservoirs, IPRA, BP 1155, F64013 Pau, France.

${ }^{4}$ Ctr Sci \& Tech Jean Feger, TOTAL, Ave Larribau, F-64018 Pau, France.

5 IFREMER, Ctr Brest, Unite Rech Etud Ecosyst Profonds, F-29280 Plouzane, France.

${ }^{6}$ UMR CEA CNRS UVSQ, LSCE, F-91198 Gif Sur Yvette, France.

*Corresponding author : Bernard Dennielou, email address : Bernard.Dennielou@ifremer.fr

\begin{abstract}
:
The detailed structure and composition of turbiditic channel-mouth lobes is still largely unknown because they commonly lie at abyssal water depths, are very thin and are therefore beyond the resolution of hullmound acoustic tools. The morphology, structure and composition of the Congo turbiditic channel-mouth lobe complex $(90 \times 40 \mathrm{~km} ; 2525 \mathrm{~km} 2)$ were investigated with hull-mounted swath bathymetry, air gun seismics, $3.5 \mathrm{kHz}$ sub-bottom profiler, sediment piston cores and also with high-resolution multibeam bathymetry and video acquired with a Remote Operating Vehicle (ROV). The lobe complex lies $760 \mathrm{~km}$ off the Congo River mouth in the Angola abyssal plain between 4740 and $5030 \mathrm{~m}$ deep. It is active and is fed by turbidity currents that deposit several centimetres of sediment per century. The lobe complex is subdivided into five lobes that have prograded. The lobes are dominantly muddy. Sand represents ca. $13 \%$ of the deposits and is restricted to the feeding channel and distributaries. The overall lobe body is composed of thin muddy to silty turbidites. The whole lobe complex is characterized by in situ mass wasting (slumps, debrites). The 1-m-resolution bathymetry shows pervasive slidings and block avalanches on the edges of the feeding channel and the channel mouth indicating that sliding occurs early and continuously in the lobe build-up. Mass wasting is interpreted as a consequence of very-high accumulation rates, over-steepening and erosion along the channels and is therefore an intrinsic process of lobe building. The bifurcation of feeding channels is probably triggered when the gradient in the
\end{abstract}


distributaries at the top of a lobe becomes flat and when turbidity currents find their way on the higher gradient on the lobe side. It may also be triggered by mass wasting on the lobe side. When a new lobe develops, the abandoned lobes continue to collect significant turbiditic deposits from the feeding channel spillover, so that the whole lobe complex remains active. A conceptual lithostratigraphic model is proposed for five morpho-sedimentary environments: lobe rims, lobe body, distributaries, levees, feeding channel. This study shows that high-resolution bathymetry ROV observations are necessary to fully understand the build-up processes of modern channel-mouth lobes.

Keywords : Congo deep-sea fan, Lobe, Lobe complex, Channel, Channel-Lobe Transition Zone, Angola basin, Slump, Slide, Debrite, Turbidite, ROV, Bathymetry, Seismic, Sediment core 


\section{Introduction}

Turbidite channel-mouth lobes (CML) here referred to as "lobes", build-up at the extremity of deep-sea turbidite channels. They correspond to the areas where turbidity currents eventually die out and accumulate their sediment load because of the loss of energy due to lack of gradient and confinement. Investigations on modern and ancient deep-sea fans have outlined a great variety of shape, structure and stacking pattern that are controlled by the composition of the sediment and by seabed morphology. However, regardless of the systems (sandy or muddy, modern or ancient), they share common features such as a diverging pattern with nested lobe-shaped bodies whose emplacement is controlled by the local compensation and by the migration of more or less shallow channels, e.g. Monterey (Klaucke et al., 2004), Nile (Migeon et al., 2010), Mississippi (Twichell et al., 1992), Amazon (Jegou et al., 2008), Zaïre/Congo (Savoye et al., 2000), Golo (Gervais et al., 2006), Tanqua Karoo (Prélat et al., 2009) or Ross formation (Macdonald et al., 2011a). They also share a narrow range of size and volumes in the order of 1-3 $\mathrm{km}^{3}$ that is interpreted as an intrinsic character (Prélat et al., 2010). Thanks to these resemblances, morpho-sedimentary classifications are converging into a hierarchy of sub-unit ranging from the bed scale (metre scale) to the lobe complex (kilometre scale) (Mulder and Etienne, 2010; Prélat et al., 2010).

Within this framework, the morphology, structure, composition and, therefore, hydro-sedimentary processes at pluri-metric scale are still badly understood and still rely on the study of fossil analogues, e.g. Tanka Karoo and Annot Sandstone Formation 
for lobes (Mulder et al., 2010; Prélat et al., 2009), Ross formation for scouring and channelling processes (Elliott, 2000; Macdonald et al., 2011a). These show that internal organization can be complex, reflecting more the processes of channel-levees formation and the 3D compensational stacking pattern of small-scale elements rather than lobewide trends (Prélat and Hodgson, 2013). On modern lobes, indeed, studies based on hull-mounted swath bathymetry and sub-bottom profiler and on sediment cores have outlined a great variability in the surface morphology, internal structure and lithostratigraphic successions (e.g. examples cited above). Although discernible, the pluri-metric scale complexity of the lobes can be resolved only by near-bottom tools such AUVs, ROVs and side-scan sonars. There actually exists very few of such data on modern lobes and they mostly consist of side scan sonar data with spatial resolutions between 0.25-12 m (e.g. SeaMARC data on Mississippi fan, (Twichell et al., 1992); MAK1 data on Rhône fan (Kenyon et al., 1995); TOBI data on the Monterey fan (Klaucke et al., 2004); SAR data on the Congo fan (Babonneau, 2002; Bonnel, 2005)). The best, documented system at pluri-metric scale is the Monterey channel-mouth lobe that was extensively surveyed with TOBI side-scan sonar from the channel mouth to its distal extremity with a spatial resolution of $6 \mathrm{~m}$. The lobe is characterised by a shallow channel (30 $\mathrm{m}$ deep) with poorly developed levees that progressively evolves into a discontinuous and shallower braided and finger like pattern that eventually disappears. The small-size channels are dominated by sand. The data also reveals recent small-scale erosional features: scours, grooves, furrows, secondary channels and blocks at the distal end of the CML (Klaucke et al., 2004). At small spatial scales, dominant sedimentary processes are frequent bifurcation of shallow channels and frequent mass wasting that result in a complex morphology and composition that can be determined only with acoustic tools of metric resolution. 
Underwater vehicles, AUVs or ROVs, are increasingly being used in geosciences to survey turbidite systems (Fildani et al., 2013; Macdonald et al., 2011b; Maier et al., 2011; Normark et al., 2009; Paull et al., 2014) and bring unprecedented views of deep-sea sedimentary systems (Wynn et al., 2014). In this paper we investigate the evolution of the Congo lobe complex and the detailed morphology and composition of lobes and feeding channels. Our investigation is based on hull-mounted swath bathymetry and seismic and on near-bottom swath bathymetry (1-m resolution DTM), seabed photos and piston cores. It contributes to document the Congo lobes at an outcrop scale and to unveil the complexity of morphology and sedimentary processes.

\section{Geological setting and previous work}

\section{The Congo fan}

The Congo fan (or turbidite system) is a mud-rich system (van Weering and van Iperen, 1984) lying at the base of the continental slope in the Angola Basin (Fig. 1). The Congo canyon, up to $1200 \mathrm{~m}$ deep, incises the continental slope and the shelf up to 30 km into the Congo River estuary. Consequently the Congo River sediments are directly delivered into the canyon and still feed the fan despite the present highstand (Babonneau et al., 2002; Droz et al., 2003; Heezen et al., 1964).

The large amount of organic carbon exported by the Congo River (14.4 Gt/yr (Coynel et al., 2005)) together with the high productivity in the Gulf of Guinea (Berger, 1989) brings a huge amount of organic carbon onto the Congo-Angola margin and the Congo fan. Consequently the sediment of the Congo fan, pelagic or turbiditic, show high Total Organic Carbon (TOC) around 1-3\% (Baudin et al., 2010; Dalibard et al., 2014; Holtvoeth et al., 2001; Jansen, 1984; Schneider et al., 1997; Stetten et al., 2015). 
The Late Pleistocene turbidite system covers about $300000 \mathrm{~km}^{3}$ and extends from the Congo-Angola continental shelf downslope to abyssal depths (5100 m) (Savoye et al., 2000). It is subdivided into three fans (Northern, Southern and Axial, in chronological order) (Droz et al., 2003; Marsset et al., 2009). The swath bathymetry acquired over the Congo fan has revealed a network of sinuous channel-levees and lobes with a diverging pattern and a starting point at the Congo canyon (Babonneau et al., 2002; Droz et al., 2003; Droz et al., 1996; Picot et al., 2016). The present and only active channel is connected to the canyon and extends $760 \mathrm{~km}$ downslope to the west, in the abyssal plain at $4950 \mathrm{~m}$ water depth where it vanishes. One remarkable feature of the active channel is the thalweg deep incision, up to $100 \mathrm{~m}$ below the base of the levees (Babonneau et al., 2002). Although not fully understood, this entrenchment is believed to be a consequence of the canyon incision into the shelf that prolong along the whole active turbidite channel to maintain a smooth and regular equilibrium profile of the thalweg (Babonneau et al., 2002).

Most of the studies dealing with a detailed analysis of sedimentary facies of the Congo fan show that terrigeneous mud is clearly the dominant fraction (Bornhold, 1973; Gervais et al., 2001; Heezen and Drake, 1964; Migeon et al., 2004; Savoye et al., 2009; van Weering and van Iperen, 1984). Silts or sand intervals are common, but restricted to specific areas. The levees are dominantly muddy and gradually coarsen downchannel (Migeon et al., 2004). This is a consequence of the confinement of turbidity currents along the channel that hinders the overflow of the coarse fractions over a long distance. Thus, silt and sand overflow only $650 \mathrm{~km}$ down-channel (Migeon et al., 2004) and sedimentation rates on levees abruptly increase fourfold to reach $4 \mathrm{~m} . \mathrm{ka}^{-1}$ after $850 \mathrm{~km}$ when the channel becomes less than $100 \mathrm{~m}$ deep (Savoye et al., 2009). The channel is 
commonly characterized by the occurrence of medium to coarse sand with muddy layers or mudclasts (Gervais et al., 2001; Migeon et al., 2004).

\section{Turbidity currents}

Turbiditic activity in the Congo canyon is attested since the $19^{\text {th }}$ century by recurrent ruptures of submarine telecommunication cables (Heezen et al., 1964). Recently, monitoring of the deep-sea channel with mooring lines equipped with sediment traps and current meters (Khripounoff et al., 2003; Vangriesheim et al., 2009a) also revealed the present-day turbidite activity in the Congo channel and on the levee at more than $4000 \mathrm{~m}$ of water depth. Savoye et al. (2009) also reported about a ROV dive inside a turbidity current in 2002. Lastly, Holocene turbiditic deposits were also evidence by radiocarbon dating along the channel-levees and on the lobes (Migeon et al., 2004; Savoye et al., 2009).

Sediment failures in the canyon or along the channel seem to be a common trigger mechanism because muddy to silty "Bouma” type turbidites with normal grading are commonly turbidites described on the fan (van Weering and van Iperen, 1984) and along the active channel-levee (Gervais et al., 2001; Migeon et al., 2004). Hyperpycnal flows have never been observed nor monitored but evidence of their occurrence was brought by the description of hyperpycnites (Mulder et al., 2003) on the levees of the active channel (Migeon et al., 2004). The recurrence of turbidity currents can be high in the canyon, up to 60 per century (Heezen et al., 1964), but is probably much lower in the channel with ca. 2 turbidites deposited per century (Savoye et al., 2009).

Study area: the lobe complex 
Terminal lobes are very common on the Late Pleistocene Congo fan and have been identified at the extremity of most of the channel-levees (Droz et al., 2003; Marsset et al., 2009; Picot et al., 2016) where they commonly occur as lobe clusters. The terminal lobe cluster of the active channel, also called lobe complex, lies between 4740 and 5030 m water depth, at about $760 \mathrm{~km}$ from the Congo River estuary (Savoye et al., 2009; Savoye et al., 2000). The lobe complex shows several diverging distributaries and a round smooth outer rim (Savoye et al., 2000). It is still presently active and receives sediments as evidenced by a current speed peak of $8.4 \mathrm{~cm} \cdot \mathrm{s}^{-1}$ and high input of sediment (Vangriesheim et al., 2009a) recorded on the $4^{\text {th }}$ February 2004 by current meters and sediment traps deployed $60 \mathrm{~m}$ above the sea floor on the lobe area. High sediment accumulation $\left(\sim 0.5\right.$ to $20 \mathrm{~cm} \cdot \mathrm{y}^{-1}$, calculated by ${ }^{210} \mathrm{~Pb}_{\mathrm{exc}}$ and ${ }^{137} \mathrm{Cs}$ analysis (Rabouille et al., 2009; Rabouille et al., this issue) indicates that the lobe complex has considerably grown over the last century. Based on AMS radiocarbon dating, Savoye et al. (2009) have suggested that the onset of the lobe complex was between 6.7 and 5.1 ka BP. However, a comprehensive chronostratigraphic analysis of the fan suggests that it developed after 4 ka BP (Picot, 2015).

\section{Data and methods}

This study is based on data acquired during Zaïango (Cochonat, 1998; Savoye, 1998), ZaïangoSAR (Savoye, 2000), ZaïangoROV (Savoye and Ondréas, 2000), WACS (Olu, 2011) and Congolobe (Rabouille, 2011) cruises.

\subsection{Bathymetric and acoustic backscatter data (Table 1)}

Hull mounted EM12 multibeam bathymetry and backscatter data were acquired over the whole lobe complex and processed with Caraibes software of IFREMER to produce a 
$100 \mathrm{~m}$ spatial resolution grid (http://flotte.ifremer.fr/fleet/Presentation-of-thefleet/On-board-software/CARAIBES). On backscatter images, dark tones correspond to high backscatter and light tones to low backscatter.

\subsection{Seismic data}

Details on numbering, configurations and resolutions of used seismic lines (6 channels, 96 channels and very high-resolution $3.5 \mathrm{kHz}$ echo-sounder) are summarized in Table 1. Seismic data were processed using PROMAX software.

Echo-sounding data $(3.5 \mathrm{kHz})$ were acquired using either a hull-mounted system (lines labelled Z1 or Z2) or the SAR (Système Acoustique Remorqué) deep-tow system (lines labelled ZSAR). Location on seismic profiles is shown in Fig. 2 and Supplementary Material SM1.

\subsection{Side scan sonar data}

Side scan sonar lines were acquired with the SAR deep-tow system (Farcy and Voisset, 1985). The vehicle was towed at about $100 \mathrm{~m}$ above the sea-floor at a speed of two knots. Sonar frequencies are 170 and $190 \mathrm{kHz}$ and the resolution of images is $0.25 \mathrm{~m}$ across and $1 \mathrm{~m}$ along track. On the images dark tones correspond to high backscatter and light tones to low backscatter. Location on SAR profiles is shown in Fig. 2 and Supplementary Material SM1.

\subsection{ROV data (multibeam, video and photomosaic)}

ROV multibeam bathymetry, video and photomosaic were acquired at three sites on the active feeding channel (Fig. 2): Site A, at the entrance of lobe complex and close to the most proximal lobe (see Section 4, lobe \#1) and Sites F and C respectively at the 
entrance and at the termination of the feeder channel of the most distal lobe (see Section 4, lobe \#5). Videos were also acquired on lobe \#3 (site B).

The ROV bathymetry was acquired with the Reson Seabat7125 operated at $60 \mathrm{~m}$ above the seabed at a speed of $0.4 \mathrm{~m} . \mathrm{s}^{-1}$. Data were processed using the IFREMER software suite Caraibes and converted into $1 \mathrm{~m}$ resolution grids.

Photomosaics acquired with the OTUS vertical downward facing camera at 8 meters above the seabed (Rabouille et al., this issue; Sen et al., this issue) allows for features of less than $10 \mathrm{~cm}$ to be resolved.

\subsection{Sediment cores}

Twenty-three piston cores (lengths between 1.80 and $19.76 \mathrm{~m}$ ) were collected over the study area during the Zaïango, Zaïrov, WACS and Congolobe cruises (cf. Figs. 2, 7, 9 and 11 for location). Cores were split lengthwise, photographed with a digital camera and a detailed description of the lithofacies was made.

\section{Morphology and structure of the lobe complex}

The study area lies at abyssal depths between 4300 and $5100 \mathrm{~m}$ at the extremity of the active turbidite channel of the Congo fan (Babonneau et al., 2002; Savoye et al., 2000) (Fig. 2). On an average regional slope of $1: 410\left(0.14^{\circ}\right)$ to the SW, the dominant morphological feature is a low sinuosity channel with a NE-SW direction that progressively vanishes to the SW (Fig. 2). Other channels are visible but they are not related to the active channel and are not the purpose of this study. Though the area looks very flat. Processing of bathymetric data by subtracting the regional trend has shown that it features a lobe shaped positive relief of around $50 \mathrm{~m}$ thick that is 
interpreted as the sediment deposited at the extremity of the active channel (Picot et al., 2016).

On the multibeam acoustic backscatter map (Fig. 3), the positive relief shows dominantly high backscatter that contrast with an adjacent low backscatter, as also observed on the Mississippi lobes (Schwab et al., 1996b), Monterey lobe (Klaucke et al., 2004), Nile lobes (Migeon et al., 2010) or Western Corsica and Sardinia lobes (Kenyon et al., 2002). Other lobe-shaped high backscatter areas are visible to the northern and southern sectors in Fig. 3. They are connected to abandoned channels and correspond to older channel-mouth lobe deposits (Picot et al., 2016).

The high-backscatter study area is about $90 \mathrm{~km}$ long and a maximum of $40 \mathrm{~km}$ wide in the middle (Fig. 3). Inside this area, small areas with lower backscatter characterize (i) elongated finger-shaped features within the high backscatter, corresponding to very shallow 10-15 m deep distributaries connected to the active channel and (ii) the sides of the feeding channel, representing the adjacent levees.

On the seismic data, the high backscatter areas correspond to lens-shaped bodies with discontinuous high-amplitude reflector (Figs. 4A, 4C and supplementary material SM3 and SM4). The base of this seismic facies is difficult to determine, but the lens-shaped bodies could be few tens of metres thick with a maximum of $\sim 70 \mathrm{~m}$. On the $3.5 \mathrm{kHz}$ lines the lens-shaped bodies correspond to a non-penetrative facies (Figs. 4B, 4D, 4E, 4F and supplementary material SM4). The low backscatter areas (outside the lobe shapes) correspond to a stratified facies both on seismic and $3.5 \mathrm{kHz}$ lines (Figs. 4C, 4D) and are interpreted as the background pelagic sediments on which lie the lens-shaped bodies (Figs. 4C, 4D, 4F). No draping is observed on these bodies. The lower backscatter 
observed along the upper part of the feeding channel corresponds to $10 \mathrm{~m}$ thick wedgeshaped bodies (Figs. 4A and 4B). These bodies are characterized by a seismic and 3.5 $\mathrm{kHz}$ transparent facies interpreted as thin levee deposits similar to those described along the channel-levees all over the Congo fan (Babonneau et al., 2002; Droz et al., 2003; Picot et al., 2016).

The seabed morphology and the acoustic and seismic facies show 5 adjacent, partially stacked, lobes (Fig. 5). Seismic data alone do not help constraining a stratigraphic order for the lobes. However, bathymetric profiles along the feeding channel and distributaries (Fig. 2 and Fig. 6) show that the channel bifurcation points correspond to positive steps of $20-30 \mathrm{~m}$ indicating that the upstream lobe (\#1) is the oldest and the downstream lobe (\#5) is the youngest. This shows that the lobes have migrated downstream to the SW so that the area corresponds to a lobe cluster or lobe complex (Fig. 5). Upstream, lobes \#1 to \#4 are partially overlapped by levees to the south (Figs. 4 and 5).

Lobe sizes as well as lobe complex size are summarised in Table 2 and are similar to those in the Prélat et al. (2009) classification. Similar sizes were also described at the extremity of the channel-levees all over the Congo fan (Picot et al., 2016).

\section{High-resolution morpho-sedimentary features along the lobe complex}

Congolobe ROV bathymetric acquisitions imaged the high-resolution morphologies at 3 sites (A, F, C) along the feeding channel of the lobe complex (see Section 3, Fig. 2). The main morphological features of the sites are given in Table 3. The high-resolution maps revealed a complex topography of the channels and their sides, and an unexpected abundance of collapsed features and bedforms. 


\subsection{Channel morphologies}

About $30 \mathrm{~km}$ downstream of the entrance of the lobe complex (Fig. 2) (Site A), the active channel is clearly visible ( $45 \mathrm{~m}$ deep, $1 \mathrm{~km}$ wide, Table 2 and Fig. 7). It is asymmetrical (Fig. 7B) with a steep outer flank to the north and a gentle inner flank to the south in concordance with the NE-SW. $45^{\circ}$ bend (Fig. 7A). Such asymmetry was already described in the Congo channel-levee (Babonneau et al., 2010) and in other meandering deep-water channels (Schwenk et al., 2003). The channel seabed shows 3 distinct morphological domains (Fig. 8D): (1) the deepest part of the channel which is rather flat $\left(0-3^{\circ}\right)$ and smooth, (2) southward, the middle part of the channel with gentle slope northwards $\left(8^{\circ}\right)$ showing small terraces on top of which a rough morphology is interpreted as a field of blocks (see Section 5.2) and (3) further south, a constant northward gradient of ca. $7^{\circ}$ where crests of symmetrical dune are perpendicular to the channel (see Section 5.3).

To the north of site A (Fig. 7A), a shallower, wider and flat-bottomed channel is visible on the levee (Table 3). In the middle of this channel runs a smaller (200 m wide and $5 \mathrm{~m}$ deep) secondary channel (Fig. 7B). The orientation of this northern channel on the regional bathymetry shows that it was previously connected to the feeding channel before the latter bifurcated to the south.

At site F, $40 \mathrm{~km}$ downstream, the channel becomes much wider (Table 3) (Fig. 9) and comprises a flat and smooth central secondary channel upstream (Fig. 10B) becoming wider and deeper downstream (Fig. 9). To the south, several highs and lows are aligned along the channel direction (Fig. 10D). The lows are flat and smooth while dunes perpendicular to the channel (Fig. 10D) are present on the highs (see Section 5.3.1). The adjacent channel sides are blocky especially to the east (see Section 5.2.1, Figs. 10C). The 
morphology is slightly smoother to the north-west where distance to the central channel and altitude increase (Fig. 9 and 10A).

At site C (Table 3), $25 \mathrm{~km}$ downstream, the channel nearly vanishes on the lowresolution bathymetry (Fig. 11). The high-resolution bathymetry however shows a rather flat, large $(5 \mathrm{~km})$ and shallow $(8 \mathrm{~m})$ channel (Fig. 11B). Its floor is marked by numerous small-scale features that include blocks, lineaments and dunes (Fig. 12A) (see Sections 5.2 and 5.3). The channel is defined on SAR side-scan sonar data by very low backscatter with lineaments parallel to the channel (Fig. 13). The associated deep-tow $3.5 \mathrm{kHz}$ line shows 8-m thickness of a transparent seismic facies filling the channel. The channel edges display a rough blocky morphology (Fig. 11 and 12) similar to site F (Fig. 9) and show a high backscatter on the deep-tow side-scan sonar and a high amplitude facies on $3.5 \mathrm{kHz}$ lines (Fig. 13).

\subsection{Mass wasting morphologies}

On the regional low-resolution bathymetry the seabed appears rather smooth (Fig. 2) but the 1-m resolution bathymetry revealed a drastically different view, with abundant morphological features indicative of either mass wasting (slides and blocks, Table 4) or current activities (bedforms, Table 5) over all the surveyed areas.

\subsubsection{Slides and blocks}

Based on the bathymetry and seabed photos the mass wasting features can be classified into several categories (Table 4).

Circular headwalls without downslope blocks are observed along the southern flank of the feeding channel and along the southern flank of the secondary channel at site A (Fig. 7). The absence of blocks near these headwalls suggests that most of the collapsed material was evacuated into the channel, probably reworked by turbidity currents. 
However, ROV videos show numerous small scale (Table 4) boulders partly draped by sediments (Fig. 14, photo A2). Unsuccessful attempts to collect samples with the ROV push corer suggest that boulders are made of soft cohesive mud. These headwalls are interpreted as slides or slump scars (Mulder and Cochonat, 1996).

Headwalls with downslope blocks are observed along the northern flank of the shallow channel at site A in large scale (500 m long) curved headscars (Fig. 7 and 8A). The base of the headscars shows hectometric, elongated blocks in the upper part evolving to decametric squared or rounded blocks in the lower part (Fig. 8C). The morphology, orientation and size of blocks plead for retrogressive slides that froze rapidly. ROV video shows that the blocks are partly buried and form rounded elongated hills (cf. Supplementary Material SM6, photos A5 and A6). Where blocks are still devoid of drapes, they show sharp angles and stratified facies (cf. supplementary material SM6, photo A7).

Block fields not associated to headscars are very common and constitute the whole of the channel sides at sites $\mathrm{F}$ and $\mathrm{C}$. Several categories can be defined according to the block sizes, from hectometric to decimetric scale (Table 4). The abundance of these blocks demonstrates that sliding is the main erosional process of the outer flanks of the feeding channel of the lobes. Where observable, blocks generally show a stratified facies with decimetric strata.

\subsubsection{Fluid, plastic deformations}

The channel seabed at site $\mathrm{C}$ displays reliefs with low amplitudes of only few a metres. When illuminated with low-angled light, the high-resolution bathymetry reveals complex arcuate morphologies outlined by downstream convex lineations (Fig. 12A). Close up views and dip bathymetric sections show up to ca. $0.7 \mathrm{~m}$ thick bulges that are 
outlined by arcuate ridges of 5-10 $\mathrm{cm}$ amplitude (Figs. 12B and 12C). In contrast strike morphology shows a 0.5 to $1 \mathrm{~m}$ depression. Such morphological features are commonly described at the toe of marine landslides as compression ridges (Laberg and Vorren, 2000; Mulder and Cochonat, 1996; Prior and Coleman, 1982) and are also common in subaerial earthflows where low velocity plastic deformation occurs (Glastonbury and Fell, 2008; Highland and Bobrowsky, 2008; Mountjoy et al., 2009). These features can therefore be interpreted as small-scale slumps, i.e. cohesive coherent sediment where plastic deformation has occurred (Shanmugam and Wang, 2015). Noteworthilly, dunes of metric wavelength and centimetric amplitude may be superimposed to the pressure ridges (Figs. 12B and 12C) (see Section 5.3).

\subsection{Bedforms}

The main features of the bedforms observed on the Congo lobe complex, including undulations and scour marks, are summarised in Table 5.

\subsubsection{Undulating bedforms}

Several undulations were described at the three sites (Table 5). They vary in terms of shape (symmetrical or asymmetrical), height $(0.10$ to $4 \mathrm{~m})$ and wavelength $(0.15$ to 150 m). Their orientations are generally perpendicular to the channel direction, and their continuity varies $<50 \mathrm{~m}$ up to $400 \mathrm{~m}$. They frequently show wavy crests. Based on morphological criteria provided in Table 5, the 3 main categories of undulations can be interpreted as 3D large (at Site A), medium (at Site F) and small (at Site C) dunes (Ashley, 1990).

\subsubsection{Scour marks}


Numerous circular reliefs surrounded by a moat and prolonged by a depression forming a tail (white arrows in Fig. 8B) are observed at site A, at the head of the northern shallow channel (Table 5). Some depression tails without central blocks are also observed. These features are scour marks (or obstacle marks) (Richardson, 1968) that have developed around sediment blocks, lying on or embedded in sediment. The depression is caused by local non-uniformity of the flow and the depression tail is aligned downstream in the current direction (Richardson, 1968). Similar bedforms are, for instance, commonly found around shipwrecks in tidal environments (Garlan et al., 2015). The obstacles at the study area are sub-circular blocks of various sizes (from 1 up to $15 \mathrm{~m}$ wide, but commonly $5-10 \mathrm{~m}$ wide, and up to $3 \mathrm{~m}$ high). The size of the moats and depression tails appears related to the obstacle size (Fig. 8B, profile A3-A3').

The orientation of the depression tails varies over the area from NE-SW on the eastern part to E-W on the western part of the area (Figs. 7B, 8B, see arrows) and are a good indicator of the current direction on the seabed.

\section{Lithofacies}

Four lithofacies and six lithofacies associations were determined on the base on the composition, colour, grain-size and structure. Their characteristics are summarized in Table 6 and photos are shown in Fig. 15 and in Supplementary Material SM9 and SM10.

Type A, pelagic lithofacies (Fig. 15A), corresponds to either carbonate or siliceous ooze. They were found only in sediment cores retrieved at the rim of lobes \#3, \#4 and \#5 (Fig. 5). They occurred either as $12 \mathrm{~m}$ thick sequence (core KZR-08, Fig. 15A), stratified with muddy turbidites (Fig. 15E), but also embedded in slumps (core WACS-06, Fig. 15F) or 
as clasts in sandy debrites in the feeding channel and in muddy debrites at the rim of lobe \#5 (core KZR-03, Fig. 15H).

Type B, turbidite structureless soft mud (Fig. 15B) (Bouma, 1962), occurs on top of three cores that were retrieved in the feeding channel at site C (KZR-06, thickness $4 \mathrm{~m}$ ) and site A (KZR-11, thickness $10 \mathrm{~cm}$ ) and in a distributive channel of lobe \#4 (KZR-10, thickness $30 \mathrm{~cm}$ ) (Figs. 2, 3, 8). At site $\mathrm{C}$ it is correlated to the transparent $3.5 \mathrm{kHz}$ facies that fills the channel (Fig. 13) and corresponds to deposit of the last turbidity current that flowed in the channel, as indicated by the minimum age of 50 years measured by ${ }^{137} \mathrm{Cs}$ in this lithofacies at site C (Rabouille et al., this issue) and consistent with the rate of 2 turbidites per century (Savoye et al., 2009).

Type C, turbidite laminated mud and silt (Fig. 15C), is typically levee deposits, induced by overflow of turbidity currents (Fig. 16). It was found throughout the lobe complex in variable proportions. The levees at the entrance of the lobe complex are composed totally of this lithofacies (cores KZR-12, CoL-A-CS01). It also represents $60 \%$ of the lobe body sediments (cores KZAI-09, KZR-09) and ca. 50\% of the deposits at the lobes rim alternating with pelagic oozes. However, at the rim of lobes \#3 and \#5 this lithofacies represents the deposits of older buried lobe complexes (Fig. 5).

Type D, turbidite clean sand (Fig. 15D), was found in the active channel (cores KZAI-07 and KZR-06) and in distributaries. It is similar to the sand found upstream in the active turbidite channel (Gervais et al., 2001; Migeon et al., 2004). 
Type E, alternating muddy turbidites and pelagic (Fig. 15E), was found at the rim of the lobes (cores WACS-06 and KZAI-10).

Types $\mathrm{F}$ and G, folded or faulted muddy turbidite (Fig. 15F and 15G), are interpreted as slump or slide deposits. Type F shows folds only while type G shows also faults with centimetric offset. They were found in close association with muddy turbidites and muddy conglomerate (see section 6.2 .5 below) and are very common on the side of the feeding channel where a blocky morphology was described. They are also observed at the extremity of lobe \#5 where the occurrence of blocks is probable (Croguennec et al., this issue).

Type H, muddy conglomerate or debrite (Fig. 15H), was found in close association with the muddy turbidites (type C) and slump/slide lithofacies (types F and G) suggesting a genetic link. It is also found on the blocky sides of the feeding channel at site $\mathrm{C}$ where blocks and plastic deformation are observed (core CoL-C-CS06) and at the extremity of lobe \#5 in association with the slump lithofacies.

Type I, matrix dominant sandy debrite (Fig. 15I), was found exclusively in the feeding channel and in distributaries. The occurrence of this facies in channels suggests a link with the channelized turbidity currents and deposition by concentrated and/or hyperconcentrated density flows (Mulder and Alexander, 2001).

Type J, clast dominant sandy debrite (Fig. 15J), probably corresponds to intermediate stages between slide (type F and G), conglomerate (type H) and debrite (type I) facies. 
As for matrix dominant sandy debrites, this lithofacies is found exclusively in the feeding channel and distributaries.

\section{Discussion}

\subsection{Significance of seismic facies and acoustic backscatter}

The lobe complex appears as a positive bulge with disorganized high-amplitude seismic reflections. On the $3.5 \mathrm{kHz}$ lines high amplitude seabed with no acoustic penetration defines both the channel and body of the lobe (Figs. 4). Low penetration facies are commonly interpreted as coarse-grained deposits as observed along the channel floor (e.g. Damuth, 1980; Droz et al., 2001; Klaucke et al., 2004; Kolla et al., 1980 ; Redbourn et al., 1993), or on channel-mouth lobes (e.g. Jegou et al., 2008; Klaucke et al., 2004; Migeon et al., 2010). Here, as expected, fine to coarse sand was recovered in the feeding channel and in the distributaries. However, lobes bodies are made of unexpected muddy slide/slump and conglomerate/debrite lithofacies (Fig. 16), contradicting the commonly accepted seismic interpretation in lobes. The rough blocky seabed (Figs. 8C, 9, 10, 12, and 14) observed on the high-resolution bathymetry and seabed photos may explain the low penetration seismic facies. This was already described on the Ebro slope where transported blocs in Big'95 debris flow deposits are characterized by low penetration seismic facies (Lastras et al., 2004) and on the Storegga slide (Haflidason et al., 2004).

Contrarily to the seismics, the acoustic backscatter clearly distinguishes between channels and distributaries (low backscatter) and lobe bodies (high backscatter) (Fig. 3). The high acoustic backscatter on the lobe bodies corresponds to the areas with rough, blocky seabed morphologies where mass wasting lithofacies have been sampled. The correlation between debrites and high backscatter was also described on the Nile lobes (Migeon et al., 2010). The low backscatter on the feeding channel and the 
distributaries correspond to sandy lithofacies (Figs. 8 and 16). A low acoustic backscatter may appear contradictory with dense coarse lithologies but is described in several sandy channel-mouth lobes (Gardner et al., 1991; Migeon et al., 2010; Unterseh, 1999; Zaragosi et al., 2000).

\subsection{Emplacement and build-up of the lobe complex}

The lobe complex lies on the flat Angola abyssal plain where gradients are in the order of 1:400 $\left(0.14^{\circ}\right)$ (Babonneau et al., 2002; Savoye et al., 2000). However it is not a smooth area as multi-beam bathymetry surveys unveiled complex morphologies with an impressive network of sinuous channels (Savoye et al., 2000). All these channels except the presently active channel are fossil turbidite channels that were once connected to the Congo canyon (Droz et al., 2003). Topographic highs and lows have controlled the emplacement and morphology of channel-levees and also of channel-mouth lobes. A detailed study of 52 lobe complexes over the Angola basin (Picot et al., 2016) revealed three morphologies and stacking patterns, divergent, divergent-prograding and dominantly prograding, respectively controlled by the increasing degree of confinement (Picot et al., 2016). Our study shows that lobe migration inside the active lobe complex was triggered by the southward shift of the feeding channel. It was favoured by the gradual infill of topographic lows and the subsequent gradual decrease of gradient on top of the lobe. When the gradient becomes null, turbidity currents divert their way to adjacent steeper gradients. This process was evoked as an intrinsic control on lobe migration and volumes (Prélat et al., 2010). This is illustrated by the depth profiles along channels and lobes (Fig. 6) where the abandonment of lobe \#4 is shown to have occurred when the local gradient at the top of the lobe reached ca. 1:600. The turbidity currents then shifted to the south to build lobe \#5 where the gradient along lobe is still 
presently ca. 1:400. A gradient of 1:600 may therefore represent the limit where turbidity currents lose their momentum, eventually die out and deposit their load, while on gradient of $1: 400$, as on lobe $\# 5$, turbidity currents may still have sufficient energy and velocity to maintain a turbulent suspension and initiate channelling processes necessary to maintain lobe progradation and aggradation. The area with a higher gradient (1:225) between lobe \#5 and the upstream bifurcation point represents a knickpoint where channel retrogressive erosion occurs in a similar way as that described for the channel-levee avulsion processes on the Amazon fan (Flood et al., 1991; Lopez, 2001), Congo fan (Droz et al., 2003) and Rhône fan (Bonnel et al., 2005; Torres et al., 1997). This is what is observed on the bathymetric profiles along lobes \#1, \#2 and \#3 where the knickpoints consecutive to channel avulsions have been erased (Fig. 6). The persistence of the knickpoint upstream lobe 5 suggests that the migration of this lobe occurred recently and that retrogressive erosion must be in progress. Although much smaller in size and occurring on shorter time scale, it is noteworthy that lobe migration occurs with similar processes as for channel-levee migration on the fan scale. One important difference is that here channel bifurcation is rather controlled more by the loss of energy of turbidity currents due to gradient decrease than by levee breaching. However frequent slides/slumps observed along the channel may also occur on the outer rim of the lobes and trigger lobe bifurcation.

One may argue that the logical corollary to lobe migration is the abandonment of older upstream lobes. However, the sediment cores collected throughout the lobe complex do not show hemipelagic deposits on top, which typically characterize turbidite starvation. On the contrary they display turbiditic facies (Fig. 16) showing that turbidity currents still reached the upstream older lobes recently. This was confirmed by ${ }^{137} \mathrm{Cs}$ activity and 
excess ${ }^{210} \mathrm{~Pb}$ activities that result in huge sedimentation rates from 0.4 (lobe 4 ) to 12 cm.yr-1 (lobe 5) (Rabouille et al., this issue). By counting the turbidites, these rates can be converted into turbidites recurrence times of 6-10 yr on the levee at Site A and 17-yr on the body of lobe \#4. From these data the most distal lobe (\#5) clearly represents the main depocentre, but the whole lobe complex receives large amounts of sediment. Therefore, one question arising is whether the recent turbidites over the lobe complex were deposited by spillover from the feeding channel or by turbidity currents funnelled along distributaries. In lobe \#3 the cores collected in distributaries (KZAI-11 and KZAI12) show turbidite laminated mud, characteristic of levees, overlying slumps and coarse sand (Fig. 16) suggesting that distributaries are inactive and progressively filled by spillover of turbidity currents from the feeding channel. On the contrary, in lobe \#4 the sand in distributaries is very close to the surface and overlain only by a thin layer of structureless very soft mud (core KZR-10), as in the feeding channel, suggesting that distributaries are still active in this lobe. The northern channel at site A, that fed lobe \#2 (Fig. 7), still receives huge turbidite spillover from the feeding channel (cf. $1 \mathrm{~cm} . \mathrm{y}^{-1}$ on the adjacent levee, core CoL-A-CS01 (Rabouille et al., this issue)), and should be partially buried by the adjacent levee of the feeding channel. However, the northern channel morphology is still very well visible and displays numerous scour marks and dunes (Fig. 8) indicating that turbidity currents recently flowed along this channel and showing that spillover from the feeding channel may be funnelled into the "abandoned" distributaries. Thus, our results clearly show that even if the channel, the lobe and therefore the main depocentre migrate, the whole lobe complex remains an important depocentre at the extremity of the Congo turbidite channel and continuous to aggrade.

\subsection{Muddy lobes with little sand}


On plan view, the low acoustic backscatter characteristics of channels (Fig. 3), represents about $13 \%$ of the surface of the lobe complex and of each lobe. Even though the internal lobe structure is not resolved on the seismics, sediment cores show that lobe bodies and rims are dominantly muddy. Since sand was found only in channels it is wise to postulate that massive sand represents only $13 \%$ of the whole lobe complex. This is explained by the sedimentological characteristics of the river and by the morphology of the turbiditic channel. The Congo fan is dominantly muddy because the rather flat hinterland of the Congo River is not prone to produce coarse sediment and because several lakes trap the coarse particles before they reach the Congo estuary (Bongo-Passi, 1984; Moguedet, 1988). Contrarily to other mud-rich fans like the Amazon (Flood et al., 1991) or the Rhône (Droz and Bellaiche, 1985), the Congo turbidic channel is deeply incised, well below the regional seafloor and the base of its own levees (Babonneau et al., 2002). The entrenchment limits the overflow of turbidity currents that starts $300 \mathrm{~km}$ downstream of the estuary (Babonneau, 2002) and becomes significant only $850 \mathrm{~km}$ downstream of the estuary, i.e. $130 \mathrm{~km}$ upstream the lobe complex (Savoye et al., 2009). Consequently, a great part of the mud of turbidity currents remains confined in the channel and reaches the channel-mouth (Babonneau et al., 2002; Savoye et al., 2009) (Figs. 3 and 5). In the lobes, where relief is low, confinement decreases. The sandy base of turbidity current freezes in channels and distributaries but muddy suspension load is maintained and spreads to become unconfined low density turbidity current which build up the muddy outer part of the lobes which is visible as a high backscatter (Figs. 3 and 8).

\subsection{Significance and origin of slumps, debrites and sediment failures}


Debrites are very common in channel-mouth lobes such as in the Mississippi (Schwab et al., 1996a), Nile (Migeon et al., 2010) and Monterey fans (Klaucke et al., 2004) and in the Karoo basin (Prélat et al., 2009). They are commonly linked with or sandwiched in turbidites suggesting a possible continuum between debris flow and turbidity currents (Haughton et al., 2003; Talling et al., 2004) and therefore a possible long run-out distance (Schwab et al., 1996a), even at low-gradient sea floor. Similarly, both muddy and sandy debrites are abundant on the Congo lobe complex since all the cores retrieved in the lobes sensu stricto (i.e. excluding the levees adjacent to the feeding channel) recovered muddy slumps/slides, conglomerates and sandy debrites, again showing a close connection between turbidites and debrites. However, the high-resolution bathymetry unveiled morphological evidences of in situ mass wasting, suggesting that a distant source must not necessarily be called to explain the occurrence of debrites on the Congo lobe complex. This is also confirmed by the lithofacies of the sediment involved in the debrites and slumps corresponding to laminated muddy turbidites, similar to those described over the lobe complex. Sandy debrites are found on the channels sides and in the channels and are interpreted as a further evolution of slumps/slides triggered on the levees and deposited in the channel. Sand injections in muddy blocks show that dismantling of the blocks also occurred in the channel. This is probably a continuum from muddy slump/conglomerate to sandy debrites. The close interaction between levee dismantling and sandy channel is clearly illustrated by the juxtaposition of the channel and rough blocky levees (Figs. 9, 11, 12, 13, and 14) and by the occurrence of blocks in the channels (Figs. 10B and 10D).

Our results show that nearly all the turbidite sediments deposited on the lobe complex collapsed shortly after deposition. This is illustrated by the sediment core WACS-06 collected at the extremity of lobe \#5 built within the last millennia (Picot et al., 2016). 
This $20 \mathrm{~m}$ long core collected slumped and fractured muddy turbidites and hemipelagic sediments that showed a marked disruption in pore water sulfate profiles. This disruption was estimated at ca. 100 yrs by modelling (Croguennec et al., this issue), showing that mass wasting is an ongoing process in the lobe complex. The occurrence of deposited $30 \mathrm{~cm}$ (i.e. deposited at a rate of ca. $0.3 \mathrm{~cm} . \mathrm{yr}^{-1}$ ) of undeformed muddy turbidites on top of the slump (Fig. 16) also shows that significant turbiditic activity occurred at this site, in the order of those calculated upstream, $(0.4$ and $22 \mathrm{~cm} . \mathrm{yr}-1$, (Rabouille et al., this issue). The Congo lobe complex lies in an area of low gradient seafloor, in the order of $1: 400\left(0.14^{\circ}\right)$ where slide triggering is not favourable. Any deposited sediments will remain stable as long as the shear strength remains superior to the shear stress and sediment collapse occurs if either the strength or the stress is modified (Canals et al., 2004). Destabilization is favoured by factors such as high sedimentation rates, sediment layering, over-steepening and fluid flow (Vanneste et al., 2014). Slope failure may then occur naturally when one of these factors reaches a threshold, but may also be triggered by an external factor (e.g. earthquake) that can affect both the shear stress and sediment shear strength. The Congo lobe complex convenes several characteristics that may actually promote mass wasting, (1) the area records very-high accumulation rates (0.4 to $22 \mathrm{~cm} \cdot \mathrm{yr}^{-1}$, (Rabouille et al., 2009; Rabouille et al., this issue) that are in the order of those measured on shallow water muddy subaqueous delta (Cattaneo et al., 2003; Kuehl et al., 1997; Kuehl et al., 1982; Liu et al., 2004; Miralles et al., 2005). This rapid accumulation may lead to excess pore pressure, underconsolidation and low shear strength. It may also lead to oversteepening as observed on the lobe edges (e.g. lobe \#4, Figs. 4, 5 and 6) where the gradient reach up to 1:225 (against 1:400 on the abyssal plain); (2) deposits consist of turbidites characterized by thin but abundant silt and sand layers that are mechanical 
discontinuities. These can behave as low shear strength weak layers and sliding surfaces (Dan et al., 2009); (3) channelling processes involve frequent erosion of the adjacent levees, especially at the outer bends of meanders (Babonneau et al., 2002; Straub et al., 2008) and lead to slope over-steepening up to $50^{\circ}$ (Fig. 5). A similar process was evoked to explain slope failure of canyon walls (Baztan et al., 2005; Sultan et al., 2007). Our data do not allow to quantify the relative importance of these parameters in the mass wasting processes. Turbidite deposition in the form of mud/silt-sand alternation generates quick aggradation and excess pore pressure that lead to failure. This is emphasized by the subsequent erosion in the levee side bordering the channel. The area shares many similarities with shallow water subaqueous delta whose development is controlled by voluminous pulses of sediment supplied by river floods, instead of turbidity currents. Subaqueous deltas are also characterized by sliding whose morphology and size are very similar to those described on the Congo lobe complex (e.g. (Maillet et al., 2006; Prior et al., 1982; Prior and Coleman, 1980). Interestingly, only a few small blocks of metric size, indicative of mass wasting were described along the feeding channel at the entrance of the lobe complex. Freshly exposed turbidites along the steep outer flank testify of the probably gradual erosion by turbidity currents. Collapsed deposits may be abundant but are likely to be evacuated by the turbidity current flowing in the channel and are therefore not preserved. However the blocky morphology of the channel floor (Fig. 8D) is a clear indication of failures of the adjacent levees.

The high-resolution bathymetry at the entrance of lobe \#5 (site C), where the channel becomes wide and shallow and eventually vanishes, reveals morphological and lithostratigraphic indications of small amplitude mass movements in the form of hectometric downstream convex lineations of small amplitude (less than $1 \mathrm{~m}$ ) on the channel floor (Fig. 12). These morphologies are interpreted as a collapse and plastic 
deformation of very low cohesion sediment. Three indications support the process deduced from this morphology: (1) the sediments collected on this morphology (core KZR-06) are very soft (nearly soupy) structureless mud resting on a thick coarse sand bed (Fig. 16). Although the cohesion was not quantified, the mud looked soft enough to flow; (2) just like the core, the $3.5 \mathrm{kHz}$ line across the channel clearly shows that the channel was filled with ca. $5 \mathrm{~m}$ of low reflectivity, and therefore low density, sediment resting on a low penetration substrate (Fig. 13); (3) very high accumulation rates (10$22 \mathrm{~cm} \mathrm{yr}^{-1}$ ) measured on core CoL-C-CS06 (Rabouille et al., this issue) (Fig. 16) i.e. one or two orders of magnitude higher that elsewhere on the lobe complex, show that the channel behaves as an ultimate sink for turbidity current and also collects the dilute upper part of the turbidity current, prone to generate low cohesion deposits.

\subsection{Origin of bedforms}

Bedforms are indicative of the interaction between bottom currents and the seabed. The high-resolution morphology of the Congo lobe complex revealed two kinds of bedforms, dunes and scour marks.

Dunes are very common in many deep-sea sedimentary environments such as on the flanks of large sediment drifts, along continental margins and on the levees of deep-sea channels. They are the subject of abundant literature (cf. review in Wynn and Stow (2002)) and are most commonly called "sediment waves" mostly to differentiate with coarse-grained dunes. Depending on the morpho-sedimentary environment they develop under the influence of contour currents, internal waves or sediment laden density current. The dunes described on both sides of the channel at site A affect both adjacent levees that are composed of muddy laminated turbidites (Figs. 8A, 8B and 16). They are perpendicular to the channel with steep side oriented downslope suggesting a 
current flowing downslope along the channel axis. The role of deep bottom current must be discarded because of their NNE residual direction (Vangriesheim et al., 2009b). Therefore, turbidity current spillovers are a good candidate, because they have the necessary velocity, sediment load and because sediment waves are very common along the Congo channel-levee (Migeon et al., 2004). The dynamics behind these dunes remains questionable. On the one hand, the dunes are perpendicular to the channel, indicating that the flow direction out of the channel was parallel to the direction of the flow in the channel therefore suggesting overbanking by overflow. On the other hand the deposits consist of base cut-out turbidites that suggest overbanking by flow spilling and stripping.

Scour marks (or obstacle marks) similar to those observed at site A (Fig. 8B) are commonly described around shipwrecks on sandy seabeds (Garlan et al., 2015) but not in muddy environments. However one may postulate that turbidity currents also accelerate around an obstacle and produce similar marks with lower deposition and may erode around and behind the obstacle. However, since turbidity currents are sediment-laden flows, obstacles are gradually buried as observed on seabed photos (Fig. 14, and supplementary material SM7, photos B3 and B4). Obstacle marks in the sediment wave field give a refined indication of the current direction. It is noted that, although they all indicate a gross WSW direction, they also show subtle changes, SW to the North and W close to the channel. This shows that turbidity currents were funnelled into the channel that fed the distributaries of lobe \#2 and is a further clear evidence that despite the fact that the feeding channel is currently connected to the most distal lobe \#5, the other lobes still collect turbidity current spillover that subsequently preferentially propagate along the distributaries. 
7.6. Initiation, development of a channel-mouth lobe and further evolution into a lobe complex in a mud-rich turbidite system

In the Congo fan the channel-mouth lobe sensu stricto corresponds to lobe \#5 that shows a continuous connection with the Congo canyon and turbidite channel over $1100 \mathrm{~km}$ (along channel length) (Fig. 1). This lobe may be considered as representative of the initial stage of a lobe build-up with a vague morphology (surface $506 \mathrm{~km}^{2}$, thickness 20 m). At this initial stage lobe \#5 is characterized by shallow distributaries (max $8 \mathrm{~m}$ ) that have limited extension and represent ca. $13 \%$ of the lobe plan view (cf. Section 7.3). Smaller distributaries, beyond the hull-mounted bathymetric resolution, may also develop to the lobe rim as possibly indicated by the finger-shaped morphology of the rim. Similar features associated with gravity flow have been described on the Tanka Karoo outcropping lobes (Groenenberg et al., 2010; Prélat et al., 2010; van der Werff and Johnson, 2003), the Mississippi fan (Twichell et al., 1992), the Rhône fan (Kenyon et al., 1993) and in the Gulf of Cadiz channel-lobe (Hanquiez et al., 2010). The origin of these finger-shaped features is unknown and they may also correspond to small slides expanding onto the abyssal plain as suggested by frequent slumps and debrites described at the rim of lobe \#5 (core WACS-06). Sediment cores clearly show that massive sand is restricted to the feeding channel and to the distributaries where it accumulates (cf. ultra-high accumulation rate of $12-22 \mathrm{~cm}^{-\mathrm{yr}^{-1}}$ at site $\mathrm{C}$ ). A significant amount of unconfined muddy suspension plume must move downstream to the lobe rim as attested by the muddy turbiditic lithofacies recovered beyond the distributaries.

Our results show that mass wasting affected the whole lobe \#5 (see Section 7.4), including the rim. Since mass wasting occurs early in lobe growth (Croguennec et al., this issue) and also involves pelagic sediment at the rim, it represents a major process in 
lobe progradation and aggradation, and more generally for its expansion onto the abyssal plain.

The abandonment of lobe \#4, after the migration of the feeding channel, leads to a knickpoint along the channel upstream lobe \#5 (Fig. 6). This indicates that erosion currently occurs in the channel as indicated by the channel entrenchment visible on the bathymetric map (Fig. 2). This erosion likely provides significant amount of sediment that made the lobe grow quickly in this initial stage which is illustrated by lobe \#5. Since the knickpoint is located on the rim of lobe $\# 4$, erosion likely reworked dominantly muddy deposits.

Lobe \#4 can be considered as representative of a fully-grown lobe that makes a marked bulge (surface $1203 \mathrm{~km}^{2}$, thickness $70 \mathrm{~m}$ ). The lobe growth pattern, until it reaches the size of lobe \#4, is difficult to determine because the internal structure is unknown. The shape, morphology, acoustic backscatter and seismic facies of lobe \#4 are rather similar to lobe \#5. For instance, on the plan view, the rim and distributaries have the same pattern. Distributaries are also very shallow and represent ca. $13 \%$ the lobe surface. This suggests that the lobe continuously grew through the same processes until a major bifurcation of the feeding channel occurred. The distribution of distributaries on the plan view and the shape of the lobe suggest that lobe \#4 has equally developed by aggradation and lateral spreading. This suggests that lobe bifurcation and emplacement is an internal process controlled by the local slope and the occurrence of an adjacent topographic low. This was also suggested by Picot et al. (2016) to explain the pattern of the Congo downfan avulsions and of their deposits.

The high sedimentation rates recorded on the abandoned lobes (0.3-0.7 cm.yr-1) (Rabouille et al., this issue) show that spillover from the feeding channel was sufficiently high to spread great quantities of sediment so that the abandoned lobes, and therefore 
the whole lobe complex, continued to aggrade significantly. However, spillover sediments will preferentially deposit on the levees that will progressively develop and bury the abandoned lobe as this is the case for lobes \#1 to \#4 (cf. site A, Fig. 4A-B and Fig. 5). Therefore the channel-mouth lobe transition is continuous with no disruption in the channel and in turbiditic processes which is a common feature for mud-rich systems (cf. reviews by Wynn et al. (2002) and by Mulder and Etienne (2010)).

\subsection{Conceptual lithostratigraphic model}

The morphologies and lateral and vertical distribution of lithofacies throughout a lobe and the lobe complex are summarized in the following conceptual stratigraphic model (Fig. 17). It consists of a schematic succession of lithofacies characterizing five morphosedimentary environments (Fig. 17).

- The lobe rims $(\log 1)$ correspond to the area where the lobe progrades and where the steepest gradients are found (Figs. 4 and 6). The lithostratigraphic succession is, from the bottom to the top (type A) pelagic lithofacies, (type E) muddy to silty turbidites alternating with pelagic intervals and corresponding to the arrival of distal turbidity current, (type F) slides/slumps involving turbidites and hemipelagic intervals that mark the time when accumulation rates are sufficiently high to trigger mass failures, (types $\mathrm{F}$ and $\mathrm{G}$ ) deformed and fractured muddy turbidites corresponding to the area of very high accumulation rates (type C) possible muddy turbidites corresponding to the most recent deposits, with still very high accumulation rates but not yet deformed. This may also correspond to distal spillover deposits from the feeding channel after the lobe 
abandonment. A pelagic interval (type A) will eventually seal the lobe after abandonment of whole lobe complex.

- The lobe bodies ( $\log 2)$ correspond to the area beyond the distributaries and where the local gradient is nearly flat. The lithostratigraphy is similar to the lobe rims, but slumped sediment are less frequent because of the lower gradient and intercalated with undeformed muddy turbidites (type C).

- The lobe distributaries (Logs 3,4 and 5) correspond to the area where the feeding channel becomes very shallow and channel migration occurs frequently. It may slightly prograde and aggrade over the lobe body. Therefore it is preceded by lithofacies types A, E, F, and G aforementioned. The distributaries environment corresponds to (type B) muddy debrites/conglomerates alternating with (type J) sandy debrites containing muddy clasts or blocks. It implies switching between collapsed muddy levees and sandy distributaries. Like for the lobe body it may be topped by muddy distal spillover turbidites (type C) and a pelagic interval (type A).

- The levees (Logs 6 and 7) correspond to the area where the feeding channel has switched to develop another lobe. The channel incised the "abandoned" lobe (cf. Site A, Fig. 7) and a levee developed. Because channel bifurcation occurs close to distributaries, the levees may develop on top of the lithofacies aforementioned. The levee lithofacies (type C) corresponds to undeformed muddy to silty turbidites. It may be topped by a pelagic interval (type A) that seals the lobe after abandonment of the whole lobe complex.

- $\quad$ The feeding channel (Logs 8 and 9) is characterized by massive sand (type D) but may also contain sandy debrites (type I and J). Upstream the bifurcation point ( $\log 9$ ), where incision is significant, sand is likely to lie on a pelagic interval 
(type A) but it may also lie on old buried lobes or levees lithofacies. Downstream from the avulsion point ( $\log 8$ ), incision is significant and there may still be a knickpoint in the channel corresponding to the rim of the abandoned lobe. Therefore sand will lie on the lobe body or distributary lithofacies.

\section{Conclusions}

The Congo lobe complex reveals an intricate morphology, structure and composition that could only be understood through ROV high-resolution data and observations.

The lobe cluster, called lobe complex that have developed at the mouth of the active turbiditic channel of the Congo fan covers an area of $2525 \mathrm{~km}^{2}$ and is composed of five lobes. The lobe complex size is ca. $90 \times 40 \mathrm{~km}$ and the lobe sizes range from 10-30 x 20$40 \mathrm{~km}$. Lobe thickness ranges between 20-70 m.

The lobe complex was developed by successive bifurcation of the feeding channel leading to a SW progradation of the lobes. The emplacement was constrained by older, abandoned, lobe complexes. Channel bifurcation occurs when local gradient, on top of a lobe, becomes too low to sustain turbidity currents and then consequently find their way onto steeper gradient on the lobe side. Sliding of lobe sides may also trigger channel bifurcation. After bifurcation, the channel profile shows a knickpoint that will eventually erode the abandoned lobe. Therefore, the Congo lobes switching process shows similarities with channel avulsion processes upstream.

Lobe switching means switching of the main depocentre at the mouth of the feeding channel. However the "abandoned" lobes upstream still received huge quantities of turbidites supplied by the spillover of poorly confined turbidity currents flowing inside the feeding channel. 
The lobes are dominantly muddy, and sand is restricted inside the feeding channel and distributaries. Distributaries, and therefore sand, represent only $13 \%$ of the plan view of a lobe. Though the internal structure of the lobes could not be determined with the seismic data, the lithofacies allow to extrapolate this estimate to the whole volume of the lobe complex.

High-resolution bathymetry and videos acquired with a ROV revealed incredibly complex morphology along the lobe complex feeding channel. It showed that several kind of mass wasting occur along the channel-sides, including block avalanches and plastically deformed masses. This was confirmed by the abundance of mass wasting lithofacies recovered in sediment cores collected throughout the lobe complex. Mass wasting is interpreted as a consequence of very-high accumulation rates (up to $22 \mathrm{~cm} . \mathrm{yr}^{-}$ ${ }^{1}$ ), and oversteepening and erosion along the channels. It is believed that mass wasting occurs in the first stages of lobe building.

Several bedforms (dunes, scours) only visible on high-resolution bathymetry show that turbidity currents plaster the seabed on very small scales. For the first time in this sedimentary environment, obstacle marks were described. They provide a refined view of turbidity currents directions.

The dataset lead to determine a conceptual lithostratigraphic model for 5 morphosedimentary environments: lobe rims, lobe body, distributaries, levees, feeding channel. It is noted that a lobe shares similarities with muddy subaqueous deltas as it is also characterized by very-high accumulation rates and by abundant mass wasting.

\section{Acknowledgements}

The authors would like to thank the captain and crew of the R/V Pourquoi Pas ?, R/V L'Atalante, R/V Le Suroit, R/V Le Nadir and Victor 6000 for their assistance during the 
expeditions conducted since 1998. We thank the chief scientists, Bruno Savoye, Pierre Cochonat, Jean-François Bourillet, Karine Olu and Christophe Rabouille and the shipboard parties. We wish to thank the technical teams involved in the acquisition and processing of swath bathymetry, seismics, side-scan sonar, ROV and sediment cores. The manuscript improved thanks to comments and suggestions by reviewer T. Mulder and and an anonymous reviewer. We thank Alison Chalm for correcting the English. Expeditions, data and studies were funded by the IFREMER-TOTAL ZaïAngo projet (PIs Bruno Savoye and Alain Morash) and by the French National Agency for Research (ANR) through Congolobe ANR Blanc SIMI5-6, no.11BS56030.

\section{References}

Babonneau, N., 2002. Mode de fonctionnement d'un chenal turbiditique méandriforme : Cas du système Turbiditique Actuel du Zaïre. Doctoral Thesis, Université Bordeaux I, Bordeaux, 308 pp.

Babonneau, N., Savoye, B., Cremer, M., Bez, M., 2010. Sedimentary architecture in meanders of a submarine channel: detailled study of the present Congo turbidite channel (Zaiango project). J. Sediment. Res. 80, 852-866. $10.2110 /$ jsr.2010.078

Babonneau, N., Savoye, B., Cremer, M., Klein, B., 2002. Morphology and architecture of the present canyon and channel system of the Zaire deep-sea fan. Mar. Pet. Geol. $19,445-467$.

Baudin, F., Disnar, J.-R., Martinez, P., Dennielou, B., 2010. Distribution of the organic matter in the channel-levees systems of the Congo mud-rich deep-sea fan (West 
Africa). Implication for deep offshore petroleum source rocks and global carbon cycle. Mar. Pet. Geol. 27, 995-1010.

Baztan, J., Berné, S., Olivet, J.-L., Rabineau, M., Aslanian, D., Gaudin, M., Réhault, J.-P., Canals, M., 2005. Axial incision, the key to understand submarine canyon evolution (in the western gulf of Lion). Mar. Pet. Geol. 22, 805-806.

Berger, W.H., 1989. Global maps of ocean productivity, in: Berger, W.H., Smetacek, V.S., Wefer, G. (Eds.), Productivity of the Ocean: Present and Past. Wiley-Interscience, New York, pp. 429-455.

Bongo-Passi, G., 1984. Contribution à l'étude lithostratigraphique, minéralogique et géochimique du delta sous-marin profond du fleuve Congo. Thèse de 3ème cycle Thesis, Univ. Toulouse, 215 pp.

Bonnel, C., 2005. Mise en place des lobes distaux dans les systèmes turbiditiques actuels: Analyse comparée des systèmes du Zaïre,Var et Rhône. PhD Thesis, Université Bordeaux 1, $314 \mathrm{pp}$.

Bonnel, C., Dennielou, B., Berné, S., Mulder, T., Droz, L., 2005. Architecture and depositional pattern of the Rhône Neofan and recent gravity activity in the Gulf of Lions (Western Mediterranean). Mar. Pet. Geol. 22, 827-843.

Bornhold, R., 1973. Late quaternary sedimentation in the Eastern Angola Basin. PhD Thesis, Massachusetts Institute of Technology and the Woods Hole Oceanographic Institution, $213 \mathrm{pp}$.

Bouma, A.H., 1962. Sedimentology of some flysch deposits. Elsevier, Amsterdam.

Canals, M., Lastras, G., Urgeles, R., Casamor, J.L., Mienert, J., Cattaneo, A., De Batist, M., Haflidason, H., Imbo, Y., Laberg, J.S., Locat, J., Long, D., Longva, O., Masson, D.G., Sultan, N., Trincardi, F., Bryn, P., 2004. Slope failure dynamics and impacts from seafloor and shallow sub-seafloor geophysical data: case studies from the 
$\begin{array}{llll}\text { COSTA } & \text { project. } & \text { Mar. }\end{array}$ http://dx.doi.org/10.1016/j.margeo.2004.10.001

Cattaneo, A., Correggiari, A., Langone, L., Trincardi, F., 2003. The late-Holocene Gargano subaqueous delta, Adriatic shelf: Sediment pathways and supply fluctuations. Mar. Geol. 193, 61-91.

Cochonat, $\quad$ P., $\quad 1998, \quad$ ZAIANGO2 cruise, $\quad$ RV L'Atalante. http://dx.doi.org/10.17600/98010110

Coynel, A., Seyler, P., Etcheber, H., Meybeck, M., Orange, D., 2005. Spatial and seasonal dynamics of total suspended sediment and organic carbon species in the Congo River. Glob. Biogeochem. Cycle 19, GB4019. 10.1029/2004gb002335

Croguennec, C., Ruffine, L., Bernard, D., Baudin, F., Caprais, J.-C., Guyader, V., Bayon, G., Brandily, C., Le Bruchec, J., Bollinger, C., Germain, Y., Droz, L., Babonneau, N., Rabouille, C., this issue. Lateral migration of methane in a complex mass wasting setting at the distal lobe of the Congo deep-sea fan. Deep Sea Research Part II: Topical Studies in Oceanography.

Dalibard, M., Popescu, S.-M., Maley, J., Baudin, F., Melinte-Dobrinescu, M.-C., Pittet, B., Marsset, T., Dennielou, B., Droz, L., Suc, J.-P., 2014. High-resolution vegetation history of West Africa during the last 145 ka. Geobios 47, 183-198. http://dx.doi.org/10.1016/i.geobios.2014.06.002

Damuth, J.E., 1980. Deep ocean sediments and their physical properties Geological models and methodology Use of high-frequency $(3.5-12 \mathrm{kHz})$ echograms in the study of near-bottom sedimentation processes in the deep-sea: A review. Mar. Geol. 38, 51-75. http://dx.doi.org/10.1016/0025-3227(80)90051-1

Dan, G., Sultan, N., Savoye, B., Deverchere, J., Yelles, K., 2009. Quantifying the role of sandy-silty sediments in generating slope failures during earthquakes: example 
from the Algerian margin. Int. J. Earth Sci. 98, 769-789. 10.1007/s00531-0080373-5

Droz, L., Bellaiche, G., 1985. Rhone Deep-Sea Fan: morphostructure and growth pattern. American Association of Petroleum Geologists Bulletin 69, 460-479.

Droz, L., Kergoat, R., Cochonat, P., Berné, S., 2001. Recent sedimentary events in the western Gulf of Lions (Western Mediterranean). Mar. Geol. 176, 23-37.

Droz, L., Marsset, T., Ondréas, H., Lopez, M., Savoye, B., Spy-Anderson, F.-L., 2003. Architecture of an active mud-rich turbidite system: The Zaire Fan (CongoAngola margin southeast Atlantic): Results from ZaiAngo 1 and 2 cruises. Am. Assoc. Pet. Geol. Bull. 87, 1145-1168.

Droz, L., Rigaut, F., Cochonat, P., Tofani, R., 1996. Morphology and recent evolution of the Zaire turbidite system (Gulf of Guinea). Geol. Soc. Am. Bull. 108, 253-269. 10.1130/0016-7606(1996)108<0253:mareot>2.3.co;2

Elliott, T., 2000. Megaflute erosion surfaces and the initiation of turbidite channels. Geology 28, 119-122.

Farcy, A., Voisset, M., 1985. Acoustic imagery of sea floor, OCEANS '85 - Ocean Engineering and the Environment, pp. 1005-1012. 10.1109/oceans.1985.1160285

Fildani, A., Hubbard, S.M., Covault, J.A., Maier, K.L., Romans, B.W., Traer, M., Rowland, J.C., 2013. Erosion at inception of deep-sea channels. Mar. Pet. Geol. 41, 48-61. 10.1016/j.marpetgeo.2012.03.006

Flood, R.C., Manley, P.L., Kowsmann, K.O., Appi, C.J., Pirmez, C., 1991. Seismic facies and late Quaternary growth of Amazon submarine fan, in: Weimer, P., Link, M.H. (Eds.), Seismic Facies and Sedimentary Processes of Submarine Fans and Turbidite Systems. Springer-Verlag, NewYork, pp. 415-434. 
Gardner, J.V., Field, M.E., Lee, H., Edwards, B.E., Masson, D.G., Kenyon, N., Kidd, R.B., 1991. Ground-truthing $6.5-\mathrm{kHz}$ side scan sonographs: What are we really imaging? Journal of Geophysical Research: Solid Earth (1978-2012) 96, 5955-5974. $10.1029 / 90 j b 02730$

Garlan, T., Marchès, E., Brenon, E., 2015. A Classification of Scouring Marks in Macrotidal Environments from Analysis of Long Term Wreck Marks, in: Wang, P., Rosati, J., Cheng, J. (Eds.), Coastal Sediments 2015, p. 14.

Gervais, A., Mulder, T., Savoye, B., Migeon, S., Cremer, M., 2001. Recent processes of levee formation on the Zaire deep-sea fan. C.R. Acad. Sci. Series IIA 332, 371-378.

Gervais, A., Savoye, B., Mulder, T., Gonthier, E., 2006. Sandy modern turbidite lobes: A new insight from high resolution seismic data. Mar. Pet. Geol. 23, 485-502.

Glastonbury, J., Fell, R., 2008. Geotechnical characteristics of large slow, very slow, and extremely slow landslides. Can. Geotech. J. 45, 984-1005. doi:10.1139/T08-021

Groenenberg, R.M., Hodgson, D.M., Prelat, A., Luthi, S.M., Flint, S.S., 2010. Flow-Deposit Interaction in Submarine Lobes: Insights from Outcrop Observations and Realizations of a Process-Based Numerical Model. J. Sediment. Res. 80, 252-267. Doi $10.2110 /$ Jsr.2010.028

Haflidason, H., Sejrup, H.P., Nygård, A., Mienert, J., Bryn, P., Lien, R., Forsberg, C.F., Berg, K., Masson, D., 2004. The Storegga Slide: architecture, geometry and slide development. Mar. Geol. 213, 201-234. http://dx.doi.org/10.1016/j.margeo.2004.10.007

Hanquiez, V., Mulder, T., Toucanne, S., Lecroart, P., Bonnel, C., MarchËs, E., Gonthier, E., 2010. The sandy channel-lobe depositional systems in the Gulf of Cadiz: Gravity processes forced by contour current processes. Sediment. Geol. 229, 110-123. 
Haughton, P.D.W., Barker, S.P., McCaffrey, W.D., 2003. 'Linked' debrites in sand-rich turbidite systems - origin and significance. Sedimentology 50, 459-482. 10.1046/j.1365-3091.2003.00560.x

Heezen, B.C., Drake, C.L., 1964. Grand Banks Slump, American Association of Petroleum Geologists Bulletin, pp. 221-233.

Heezen, B.C., Menzies, R.J., Schneider, E.D., Ewing, W.M., Granelli, N.C.L., 1964. Congo submarine canyon, American Association of Petroleum Geologists Bulletin, pp. 1126-1149.

Highland, L.M., Bobrowsky, P., 2008. The landslide handbook-A guide to understanding landslides, Reston, Virginia.

Holtvoeth, J., Wagner, T., Horsfield, B., Schubert, C.J., Wand, U., 2001. Late-Quaternary supply of terrigenous organic matter to the Congo deep-sea fan (ODP site 1075): implications for equatorial African paleoclimate. Geo-Mar. Lett. 21, 23-33.

Jansen, J.H.F., 1984. Quaternary geology and oceanography of the Zaire deep-sea fan and adjacent Atlantic, in: De Blok, J.W. (Ed.), Netherlands Journal of Sea Research, pp. $145-441$.

Jegou, I., Savoye, B., Pirmez, C., Droz, L., 2008. Channel-mouth lobe complex of the recent Amazon Fan: The missing piece. Mar. Geol. 252, 62-77. Doi 10.1016/J.Margeo.2008.03.004

Kenyon, N.H., Droz, L., Ferentinos, G., Palanques, A., Cronin, B.T., Hasiotis, T., Millington, J., Valensela, G., 1993. Sidescan sonar facies, in: Limonov, A., Woodside, J., Ivanov, M. (Eds.), Geological and geophysical investigations of Western Mediterranean deep sea fans, pp. 32-51. 
Kenyon, N.H., Klaucke, I., Millington, J., Ivanov, M.K., 2002. Sandy submarine canyonmouth lobes on the western margin of Corsica and Sardinia, Mediterranean Sea. Mar. Geol. 184, 69-84. 10.1016/s0025-3227(01)00282-1

Kenyon, N.H., Millington, J., Droz, L., Ivanov, M.K., 1995. Scour holes in a channel-lobe transition zone on the Rhône cone, in: Pickering, K.T., Hiscott, R.N., Kenyon, N.H., Lucchi, F.R., Smith, R.D.A. (Eds.), Atlas of Deep-water Environments: Architectural Styles in Turbidite Systems. Chapman and Hall, London, pp. 212215.

Khripounoff, A., Vangriesheim, A., Babonneau, N., Crassous, P., Dennielou, B., Savoye, B., 2003. Direct observation of intense turbidity current activity in the Zaire submarine valley at $4000 \mathrm{~m}$ water depth. Mar. Geol. 194, 151-158.

Klaucke, I., Masson, D.G., Kenyon, N.H., Gardner, J.V., 2004. Sedimentary processes of the lower Monterey Fan channel and channel-mouth lobe. Mar. Geol. 206, 181-198.

Kolla, V., Kostecki, J.A., Henderson, L., Hess, L., 1980. Morphology and Quaternary sedimentation of the Mozambique Fan and environs, southwestern Indian Oceans*. Sedimentology 27, 357-378. 10.1111/j.1365-3091.1980.tb01188.x

Kuehl, S.A., Levy, B.M., Moore, W.S., Allison, M.A., 1997. Subaqueous delta of the GangesBrahmaputra river system. Mar. Geol. 144, 81-96. http://dx.doi.org/10.1016/S0025-3227(97)00075-3

Kuehl, S.A., Nittrouer, C.A., DeMaster, D.J., 1982. Modern sediment accumulation and strata formation on the Amazon continental shelf. Mar. Geol. 49, 279-300. http://dx.doi.org/10.1016/0025-3227(82)90044-5

Laberg, J.S., Vorren, T.O., 2000. The Trænadjupet Slide, offshore Norway - morphology, evacuation and triggering mechanisms. Mar. Geol. 171, 95-114. http://dx.doi.org/10.1016/S0025-3227(00)00112-2 
Lastras, G., Canals, M., Urgeles, R., De Batist, M., Calafat, A.M., Casamor, J.L., 2004. Characterisation of the recent BIG'95 debris flow deposit on the Ebro margin, Western Mediterranean Sea, after a variety of seismic reflection data. Mar. Geol. 213, 235-255. http://dx.doi.org/10.1016/i.margeo.2004.10.008

Liu, J.P., Milliman, J.D., Gao, S., Cheng, P., 2004. Holocene development of the Yellow River's subaqueous delta, North Yellow Sea. Mar. Geol. 209, 45-67. http://dx.doi.org/10.1016/j.margeo.2004.06.009

Lopez, M., 2001. Architecture and depositional pattern of the Quaternary deep-sea fan of the Amazon. Mar. Pet. Geol. 18, 479-486.

Macdonald, H.A., Peakall, J., Wignall, P.B., Best, J., 2011a. Sedimentation in deep-sea lobeelements: implications for the origin of thickening-upward sequences. J. Geol. Soc. 168, 319-332. 10.1144/0016-76492010-036

Macdonald, H.A., Wynn, R.B., Huvenne, V.A.I., Peakall, J., Masson, D.G., Weaver, P.P.E., McPhail, S.D., 2011b. New insights into the morphology, fill, and remarkable longevity (>0.2 m.y.) of modern deep-water erosional scours along the northeast Atlantic margin. Geosphere 7, 845-867. 10.1130/ges00611.1

Maier, K.L., Fildani, A., Paull, C.K., Graham, S.A., McHargue, T.R., Caress, D.W., McGann, M., 2011. The elusive character of discontinuous deep-water channels: New insights from Lucia Chica channel system, offshore California. Geology 39, 327330. $10.1130 / g 31589.1$

Maillet, G.M., Vella, C., Berne, S., Friend, P.L., Amos, C.L., Fleury, T.J., Normand, A., 2006. Morphological changes and sedimentary processes induced by the December 2003 flood event at the present mouth of the Grand Rhone River (southern France). Mar. Geol. 234, 159-177. 
Marsset, T., Droz, L., Dennielou, B., Pichon, E., 2009. Cycles in the architecture of the Quaternary Zaire turbidite system: a possible link with climate, in: Kneller, B., Martinsen, O.J., McCaffrey, B. (Eds.), External Controls on Deep-Water Depositional Systems. SEPM, pp. 89-106.

Migeon, S., Ducassou, E., Le Gonidec, Y., Rouillard, P., Mascle, J., Revel-Rolland, M., 2010. Lobe construction and sand/mud segregation by turbidity currents and debris flows on the western Nile deep-sea fan (Eastern Mediterranean). Sediment. Geol. 229, 124-143.

Migeon, S., Savoye, B., Babonneau, N., Spy-Anderson, F.-L., 2004. Processes of sedimentwaves construction along the present Zaire Deep-sea meandering channel: role of meanders and flow stripping. J. Sediment. Res. 74, 580-598.

Miralles, J., Radakovitch, O., Aloisi, J.C., 2005. 210Pb sedimentation rates from the Northwestern Mediterranean margin. Mar. Geol. 216, 155-167.

Moguedet, G., 1988. Les relations entre le fleuve Congo et la sédimentation récente sur la marge continentale entre l'embouchure et le sud du Gabon: étude hydrologique, sédimentologique et géochimique. Thèse d'état Thesis, Univ. Angers, 187 pp.

Mountjoy, J.J., McKean, J., Barnes, P.M., Pettinga, J.R., 2009. Terrestrial-style slow-moving earthflow kinematics in a submarine landslide complex. Mar. Geol. 267, 114127. http://dx.doi.org/10.1016/i.margeo.2009.09.007

Mulder, T., Alexander, J., 2001. The physical character of subaqueous sedimentary density flows and their deposits. Sedimentology 48, 269-299. doi:10.1046/j.1365-3091.2001.00360.x

Mulder, T., Callec, Y., Parize, O., Joseph, P., Schneider, J.-L., Robin, C., Dujoncquoy, E., Salles, T., Allard, J., Bonnel, C., Ducassou, E., Etienne, S., Ferger, B., Gaudin, M., Hanquiez, V., Linares, F., Marchès, E., Toucanne, S., Zaragosi, S., 2010. High- 
resolution analysis of submarine lobes deposits: Seismic-scale outcrops of the Lauzanier area (SE Alps, France). Sediment. Geol. 229, 160-191.

Mulder, T., Cochonat, P., 1996. Classification of offshore mass movements, J. Sediment. Res., pp. 43-57.

Mulder, T., Etienne, S., 2010. Lobes in deep-sea turbidite systems: State of the art. Sediment. Geol. 229, 75-80.

Mulder, T., Syvitski, J.P.M., Migeon, S., Faugeres, J.-C., Savoye, B., 2003. Marine hyperpycnal flows: initiation, behavior and related deposits. A review. Mar. Pet. Geol. 20, 861-882.

Normark, W.R., Paull, C.K., Caress, D.W., Ussler, W., Sliter, R., 2009. Fine-scale relief related to Late Holocene channel shifting within the floor of the upper Redondo Fan, offshore Southern California. Sedimentology 56, 1690-1704.

Olu, K., 2011, WACS cruise, RV Pourquoi pas? http://dx.doi.org/10.17600/11030010 Paull, C.K., McGann, M., Sumner, E.J., Barnes, P.M., Lundsten, E.M., Anderson, K., Gwiazda, R., Edwards, B., Caress, D.W., 2014. Sub-decadal turbidite frequency during the early Holocene: Eel Fan, offshore northern California. Geology 42, 855-858. $10.1130 / g 35768.1$

Picot, M., 2015. Cycles sédimentaires dans le système turbiditique du Congo : nature et origine. Doctorat Thesis, Université de Bretagne Occidentale, Brest, 368 pp.

Picot, M., Droz, L., Marsset, T., Dennielou, B., Bez, M., 2016. Controls on turbidite sedimentation: Insights from a quantitative approach of submarine channel and lobe architecture (Late Quaternary Congo Fan). Mar. Pet. Geol. 72, 423-446. 10.1016/j.marpetgeo.2016.02.004 
Prélat, A., Covault, J.A., Hodgson, D.M., Fildani, A., Flint, S.S., 2010. Intrinsic controls on the range of volumes, morphologies, and dimensions of submarine lobes. Sediment. Geol. 232, 66-76.

Prélat, A., Hodgson, D.M., 2013. The full range of turbidite bed thickness patterns in submarine lobes: controls and implications. J. Geol. Soc. 170, 209-214. 10.1144/jgs2012-056

Prélat, A., Hodgson, D.M., Flint, S.S., 2009. Evolution, architecture and hierarchy of distributary deep-water deposits: a high-resolution outcrop investigation from the Permian Karoo Basin, South Africa. Sedimentology 56, 2132-U2125. Doi 10.1111/J.1365-3091.2009.01073.X

Prior, D.B., Bornhold, B.D., Coleman, J.M., Bryant, W.R., 1982. Morphology of a submarine slide, Kitimat Arm, British Columbia. Geology 10, 588-592. 10.1130/00917613(1982)10<588:moassk>2.0.co;2

Prior, D.B., Coleman, J.M., 1980. Sonograph mosaics of submarine slope instabilities, Mississippi River Delta. Mar. Geol. 36, 227-239. http://dx.doi.org/10.1016/0025-3227(80)90088-2

Prior, D.B., Coleman, J.M., 1982. Active Slides and Flows in Underconsolidated Marine Sediments on the Slopes of the Mississippi Delta, in: Saxov, S., Nieuwenhuis, J.K. (Eds.), Marine Slides and Other Mass Movements. Springer US, Boston, MA, pp. 21-49. 10.1007/978-1-4613-3362-3_3

Rabouille, C., 2011, CONGOLOBE cruise, RV Pourquoi pas ? http://dx.doi.org/10.17600/11030170

Rabouille, C., Caprais, J.C., Lansard, B., Crassous, P., Dedieu, K., Reyss, J.L., Khripounoff, A., 2009. Organic matter budget in the Southeast Atlantic continental margin close 
to the Congo Canyon: In situ measurements of sediment oxygen consumption. Deep-Sea Res Pt Ii 56, 2223-2238. 10.1016/j.dsr2.2009.04.005

Rabouille, C., Olu, K., Baudin, F., Khripounoff, A., Dennielou, B., Arnaud-Haond, S., Babonneau, N., Bayle, C., Beckler, J., Bessette, S., Bombled, B., Bourgeois, S., Brandily, C., Caprais, J.C., Cathalot, C., Charlier, K., Corvaisier, R., Croguennec, C., Cruaud, P., Decker, C., Droz, L., Gayet, N., Godfroy, A., Hourdez, S., Le Bruchec, J., Le Saout, J., Lesaout, M., Lesongeur, F., Martinez, P., Mejanelle, L., Michalopoulos, P., Mouchel, O., Noel, P., Pastor, L., Picot, M., Pignet, P., Pozzato, L., Pruski, A.M., Rabiller, M., Raimonet, M., Ragueneau, O., Reyss, J.L., Rodier, P., Ruesch, B., Ruffine, L., Savignac, F., Senyarich, C., Schnyder, J., Sen, A., Stetten, E., Sun, M.Y., Taillefert, M., Teixeira, S., Tisnerat-Laborde, N., Toffin, L., Tourolle, J., Toussaint, F., Vétion, G., Jouanneau, J.M., Bez, M., this issue. The Congolobe project, a multidisciplinary study of Congo deep-sea fan lobe complex: Overview of methods, strategies, observations and sampling. Deep Sea Research Part II: Topical Studies in Oceanography. http://dx.doi.org/10.1016/j.dsr2.2016.05.006 Redbourn, L.J., Bull, J.M., Scrutton, R.A., Stow, D.A.V., 1993. Channels, echo character mapping and tectonics from 3.5 kHz profiles, distal Bengal Fan. Mar. Geol. 114, 155-170. http://dx.doi.org/10.1016/0025-3227(93)90045-W

Richardson, P.D., 1968. The generation of scour marks near obstacles, J. Sediment. Petrol., pp. 965-970.

Savoye, B., 1998, ZAIANG01 cruise, RV L'Atalante. http://dx.doi.org/10.17600/98010100

Savoye, B., 2000, ZAIANGOSAR cruise, RV Le Nadir. http://dx.doi.org/10.17600/80010 
Savoye, B., Babonneau, N., Dennielou, B., Bez, M., 2009. Geological overview of the Angola-Congo margin, the Congo deep-sea fan and its submarine valleys. Deep Sea Research Part II: Topical Studies in Oceanography 56, 2169-2182.

Savoye, B., Cochonat, P., Apprioual, R., Bain, O., Baltzer, A., Bellec, V., Beuzart, P., Bourillet, J.-F., Cagna, R., Cremer, M., Crusson, A., Dennielou, B., 2000. Structure et evolution recente de l'eventail turbiditique du Zaire : premiers resultats scientifiques des missions d'exploration Zaiango1 \& 2 (marge Congo-Angola): Structure and recent evolution of the Zaire deep-sea fan: preliminary results of the ZaiAngo 1 \& 2 cruises (Angola-Congo margin). C.R. Acad. Sci. Series IIA 331, 211-220.

Savoye, B., Ondréas, H., 2000, ZAIANGOROV cruise, RV L'Atalante. http://dx.doi.org/10.17600/10100

Schneider, R.R., Price, B., Müller, P.J., Kroon, D., Alexander, I., 1997. Monsoon related variations in Zaire (Congo) sediment load and influence of fluvial silicate supply on marine productivity in the east equatorial Atlantic during the last 200,000 years. Paleoceanography 12, 463-481.

Schwab, W.C., Lee, H.J., Twichell, D.C., Locat, J., Nelson, C.H., McArthur, W.G., Kenyon, N.H., 1996a. Sediment mass-flow processes on a depositional lobe, outer Mississippi Fan. J. Sediment. Res. 66, 916-927.

Schwab, W.C., Lee, H.J., Twichell, D.C., Locat, J., Nelson, C.H., McArthur, W.G., Kenyon, N.H., 1996b. Sediment mass-flow processes on a depositional lobe, outer Mississippi Fan. J. Sediment. Res. 66, 916-927.

Schwenk, T., Spieß, V., Hübscher, C., Breitzke, M., 2003. Frequent channel avulsions within the active channel-levee system of the middle Bengal Fan-an exceptional channel-levee development derived from Parasound and 
Hydrosweep data. Deep Sea Research Part II: Topical Studies in Oceanography 50, 1023-1045. http://dx.doi.org/10.1016/S0967-0645(02)00618-5

Sen, A., Bernard, D., Droz, L., Decker, C., Arnaubec, A., Rabouille, C., Olu, K., this issue. Fauna and habitat types in the turbidity current driven Congo deep-sea fan lobes Deep Sea Research Part II: Topical Studies in Oceanography.

Shanmugam, G., Wang, Y., 2015. The landslide problem. Journal of Palaeogeography 4, 109-166. http://dx.doi.org/10.3724/SP.J.1261.2015.00071

Stetten, E., Baudin, F., Reyss, J.-L., Martinez, P., Charlier, K., Schnyder, J., Rabouille, C., Dennielou, B., Coston-Guarini, J., Pruski, A., 2015. Organic matter characterization and distribution in sediments of the terminal lobes of the Congo deep-sea fan: Evidence for the direct influence of the Congo River. Mar. Geol. 369, 182-195. http://dx.doi.org/10.1016/j.margeo.2015.08.020

Straub, K.M., Mohrig, D., McElroy, B., Buttles, J., Pirmez, C., 2008. Interactions between turbidity currents and topography in aggrading sinuous submarine channels: A laboratory study. Geol. Soc. Am. Bull. 120, 368-385. 10.1130/b25983.1

Sultan, N., Gaudin, M., Berne, S., Canals, M., Urgeles, R., Lafuerza, S., 2007. Analysis of slope failures in submarine canyon heads: An example from the Gulf of Lions. J. Geophys. Res. 112. doi:10.1029/2005JF000408

Talling, P.J., Amy, L.A., Wynn, R.B., Peakall, J., Robinson, M., 2004. Beds comprising debrite sandwiched within co-genetic turbidite: origin and widespread occurrence in distal depositional environments. Sedimentology 51, 163-194.

Torres, J., Droz, L., Savoye, B., Terentieva, E., Cochonat, P., Kenyon, N.H., Canals, M., 1997. Deep-sea avulsion and morphosedimentary evolution of the Rhône Fan Valley and Neofan during the Late Quaternary (north-western Mediterranean Sea). Sedimentology 44, 457-477. 
Twichell, D.C., Schwab, W.C., Nelson, H.C., Kenyon, N.H., Lee, H.J., 1992. Characteristics of a sandy depositional lobe on the outer Mississippi fan from SeaMARC IA sidescan sonar images, Geology, pp. 689-692.

Unterseh, S., 1999. Cartographie et caractérisation du fond marin par sondeur multifaisceaux. PhD Thesis, University of Nancy, 234 pp.

van der Werff, W., Johnson, S.D., 2003. Deep-sea fan pinch-out geometries and their relationship to fan architecture, Tanqua Karoo basin (South Africa). Int. J. Earth Sci. 92, 728-742. 10.1007/s00531-003-0352-9

van Weering, T.C.E., van Iperen, J., 1984. Fine-grained sediments of the Zaire deep-sea fan, southern Atlantic Ocean. Geological Society, London, Special Publications 15, 95-113. 10.1144/gsl.sp.1984.015.01.06

Vangriesheim, A., Khripounoff, A., Crassous, P., 2009a. Turbidity events observed in situ along the Congo submarine channel. Deep-Sea Res Pt Ii 56, 2208-2222. 10.1016/j.dsr2.2009.04.004

Vangriesheim, A., Pierre, C., Aminot, A., Metzl, N., Baurand, F., Caprais, J.-C., 2009b. The influence of Congo River discharges in the surface and deep layers of the Gulf of Guinea. Deep Sea Research Part II: Topical Studies in Oceanography 56, 21832196. http://dx.doi.org/10.1016/j.dsr2.2009.04.002

Vanneste, M., Sultan, N., Garziglia, S., Forsberg, C.F., L'Heureux, J.S., 2014. Seafloor instabilities and sediment deformation processes: The need for integrated, multi-disciplinary investigations. Mar. Geol. 352, 183-214. 10.1016/j.margeo.2014.01.005

Wynn, R.B., Huvenne, V.A.I., Le Bas, T.P., Murton, B.J., Connelly, D.P., Bett, B.J., Ruhl, H.A., Morris, K.J., Peakall, J., Parsons, D.R., Sumner, E.J., Darby, S.E., Dorrell, R.M., Hunt, J.E., 2014. Autonomous Underwater Vehicles (AUVs): Their past, present and 
future contributions to the advancement of marine geoscience. Mar. Geol. 352, 451-468. http://dx.doi.org/10.1016/j.margeo.2014.03.012

Wynn, R.B., Kenyon, N.H., Masson, D.G., Stow, D.A.V., Weaver, P.P.E., 2002. Characterization and recognition of deep-water channel-lobe transition zones. Am. Assoc. Pet. Geol. Bull. 86, 1441-1146.

Wynn, R.B., Stow, D.A.V., 2002. Recognition and interpretation of deep-water sediment waves: implications for palaeoceanography, hydrocarbon exploration and flow process interpretation. Mar. Geol. 192, 1-3.

Zaragosi, S., Auffret, G.A., Faugeres, J.-C., Garlan, T., Pujol, C., Cortijo, E., 2000. Physiography and recent sediment distribution of the Celtic Deep-Sea Fan, Bay of Biscay. Mar. Geol. 169, 207-237. 


\section{Figures}

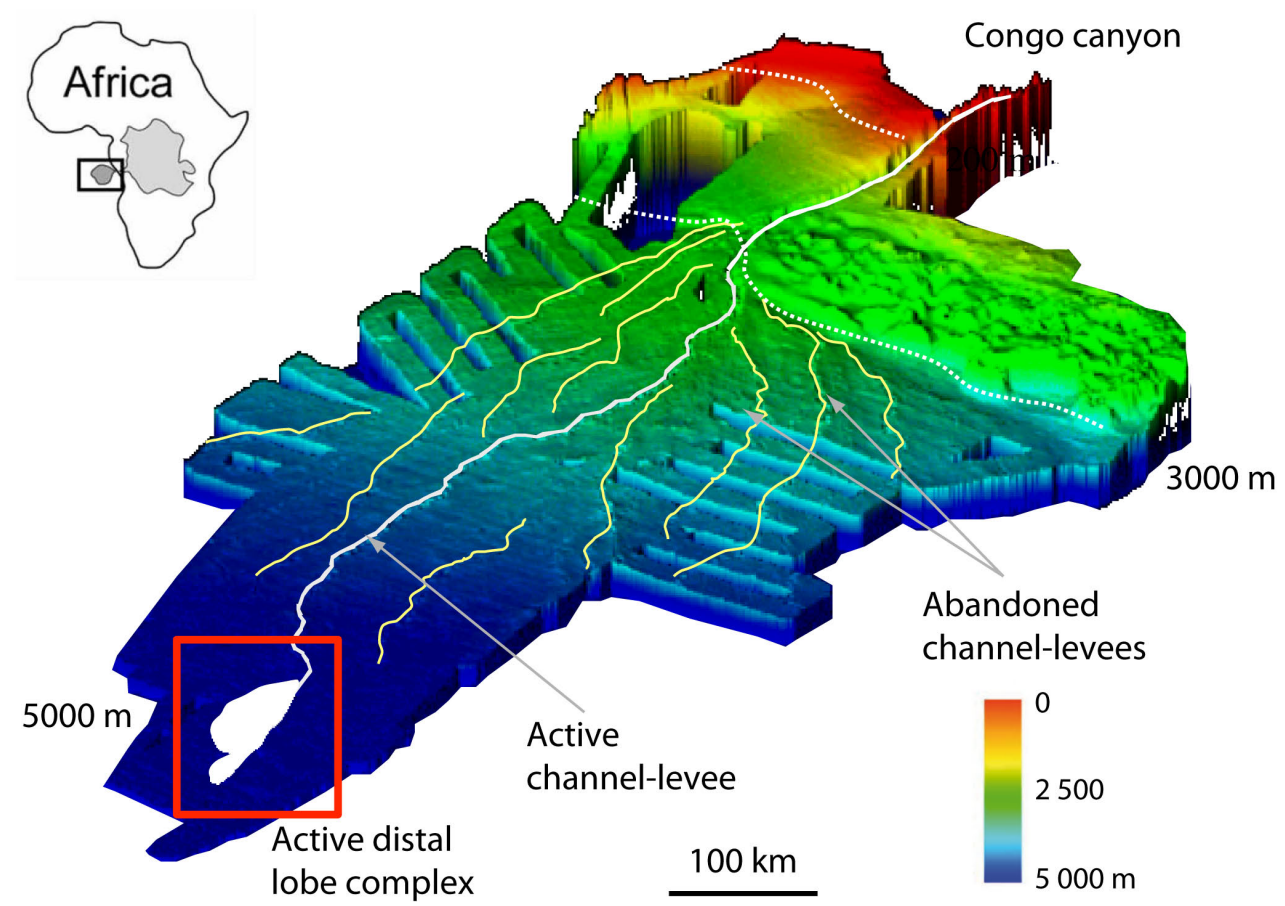

Figure 1: 3D bathymetric map of the Congo fan, adapted from Savoye et al. (2009). The white sinuous line represents the active channel that is connected to the canyon. The yellow sinuous lines represent some abandoned channels. The red square and white lobes indicate the study area shown in Figs 2 and 3. 


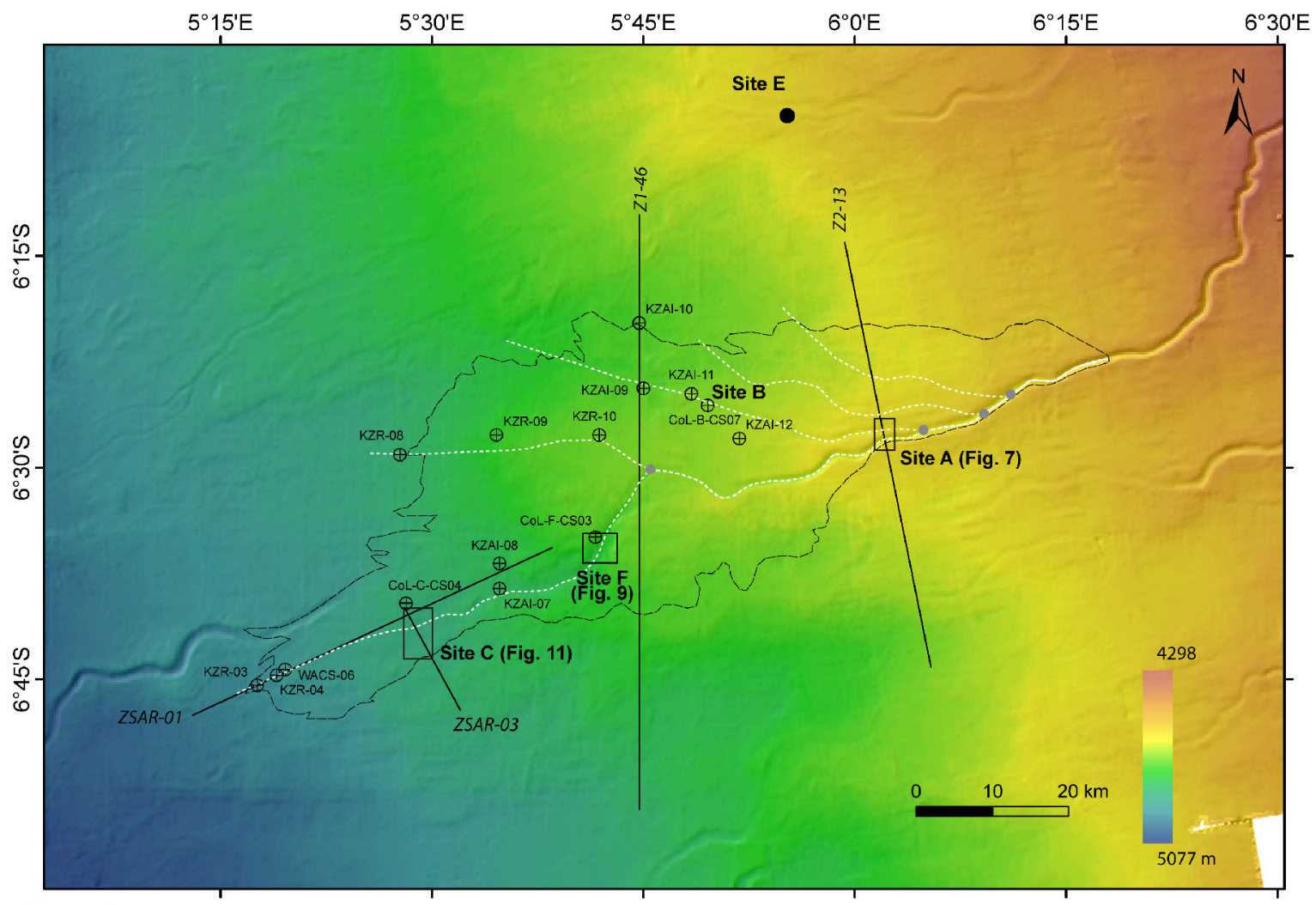

Figure 2: EM12 bathymetric map of the study area with location of sites surveyed with the ROV very highresolution bathymetry (Sites $A, F$ and $C$ ), location of sediment cores (cross in circle), seismic lines with line number (black straight lines) shown in Fig. 4. Location of additional seismic lines (SM3 and SM4) is shown in supplementary material SM1. Sites B and E, also studied during Congolobe expedition (Rabouille, 2011) but not surveyed with very high-resolution bathymetry, are also located on the map. The Congo lobe complex is outlined by the dash black line (limits reproduced from Babonneau, 2002). The white dashed lines indicate the location of the bathymetric profiles along the feeding channel and distributaries shown in Fig. 6. The grey spots indicate correspond to the channel bifurcations and show the junctions between the bathymetric profiles in Fig. 6. Map obtained by combining Zaiango and ZaiROV cruise (Cochonat, 1998; Savoye, 1998) bathymetric DTMs. See Fig. 1 for location. 


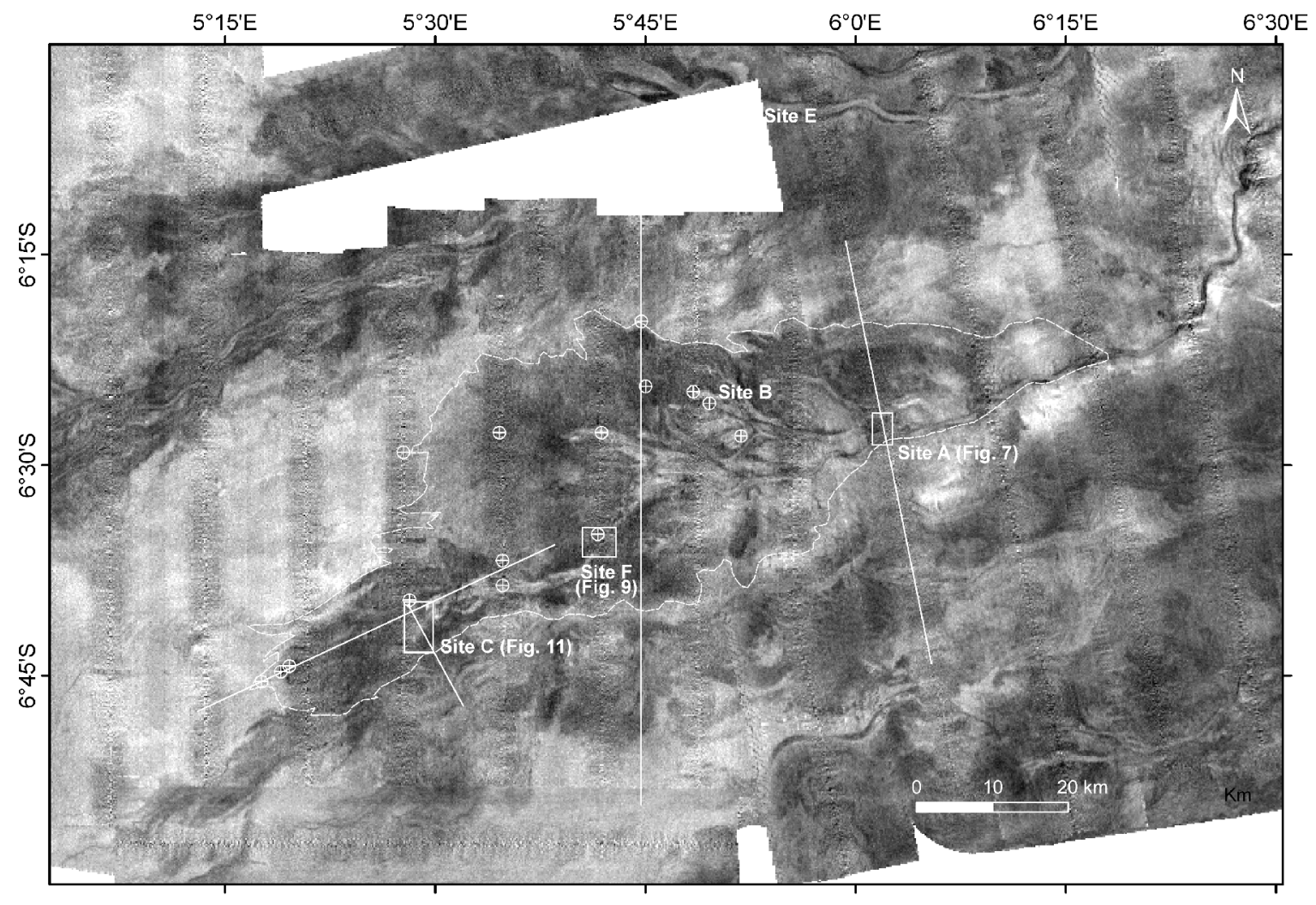

Figure 3: EM12 acoustic backscatter map of the study area (light tones: low backscatter; dark tones: high backscatter). See Fig. 1 for location and Fig. 2 for legends. 

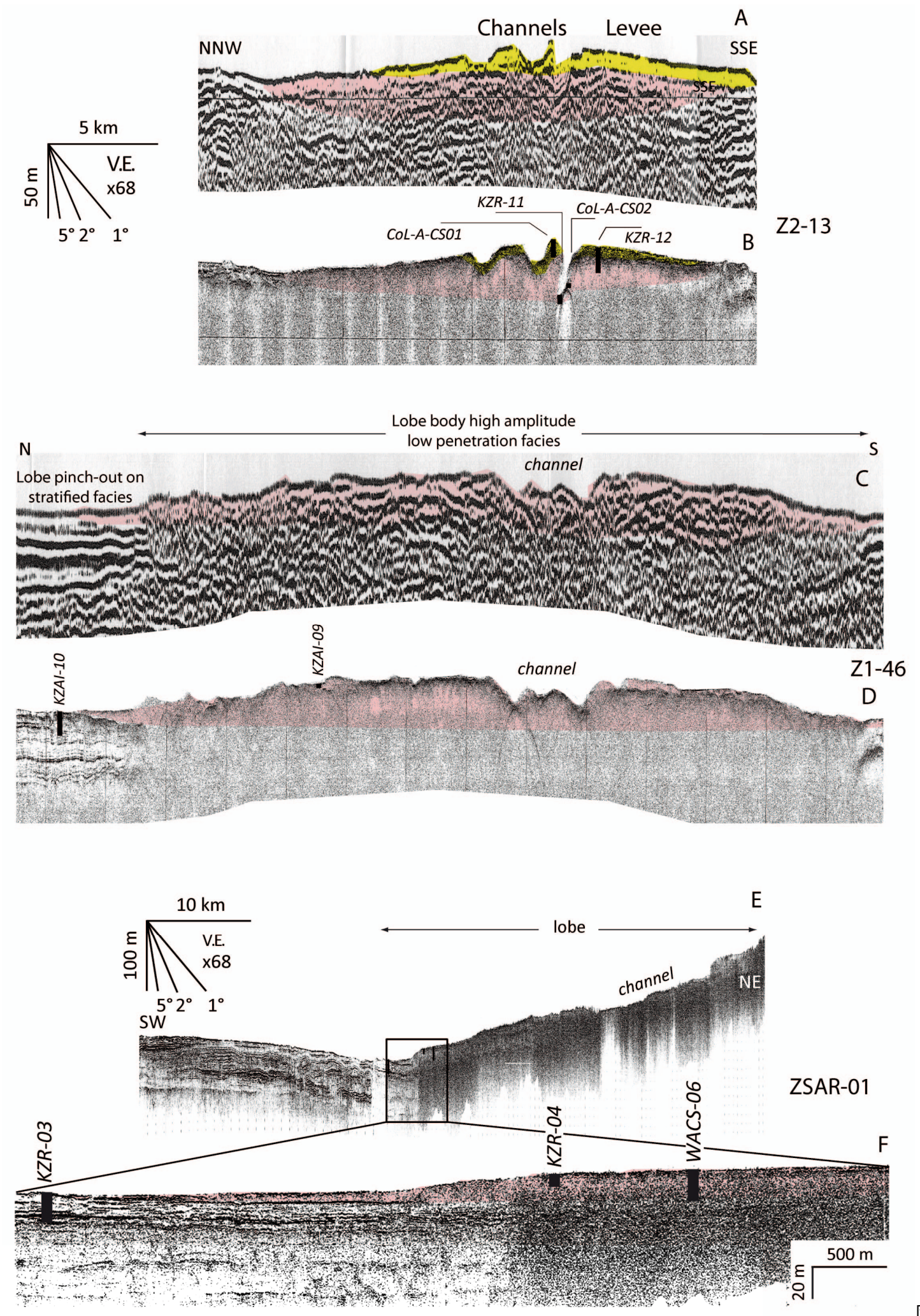

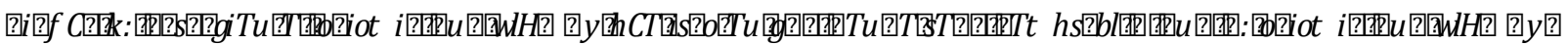

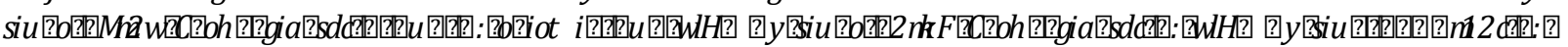

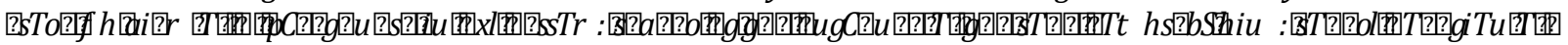

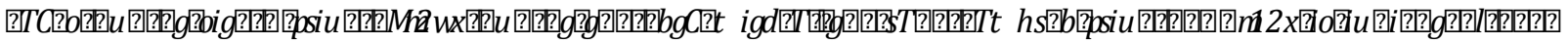

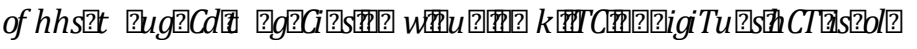




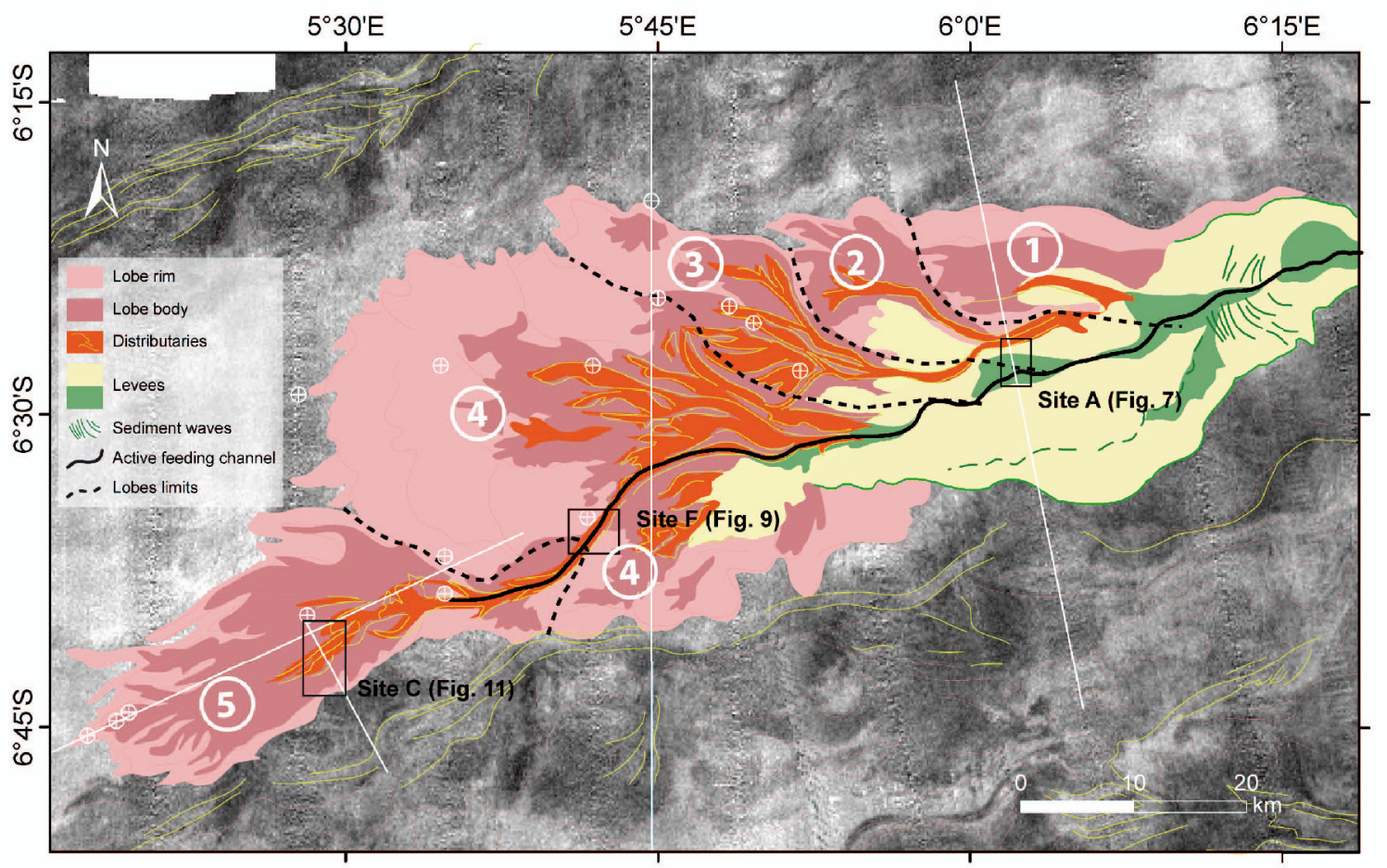

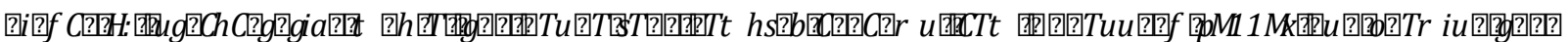

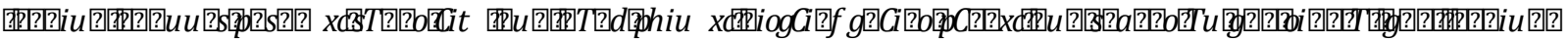

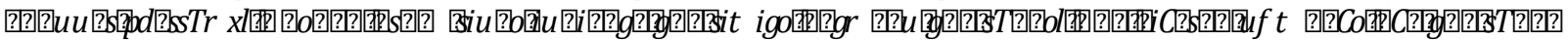

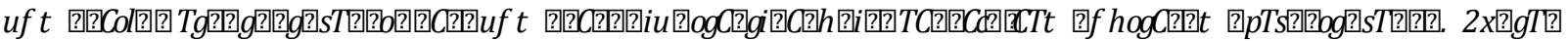

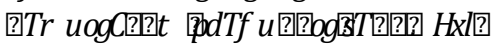




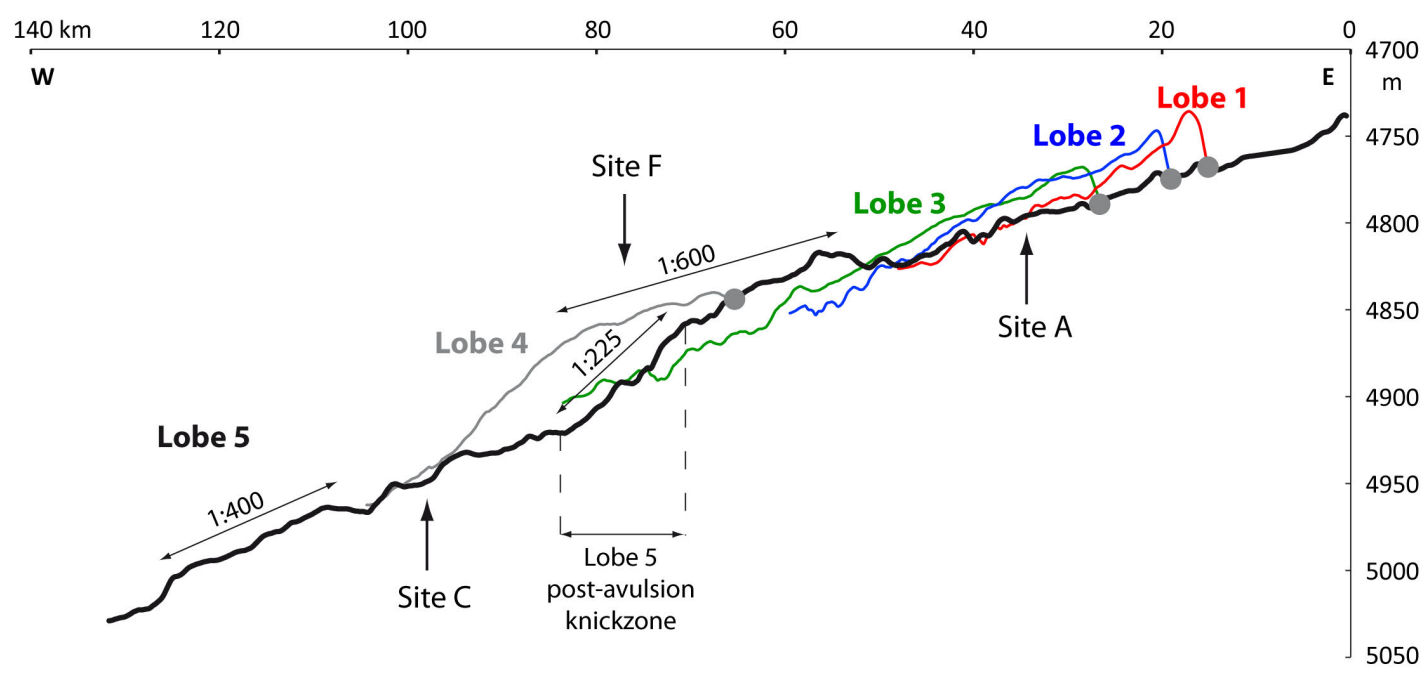

Figure 6: Bathymetric profiles along the lobes of the Congo lobe complex (see location in Fig. 2). Black, red, blue, green and grey lines are the profiles along the feeding channel and lobe \#5, lobe \#1, lobe \#2, lobe \#3 and lobe \#4 respectively. The locations of sites A, F, C are indicated. 
A
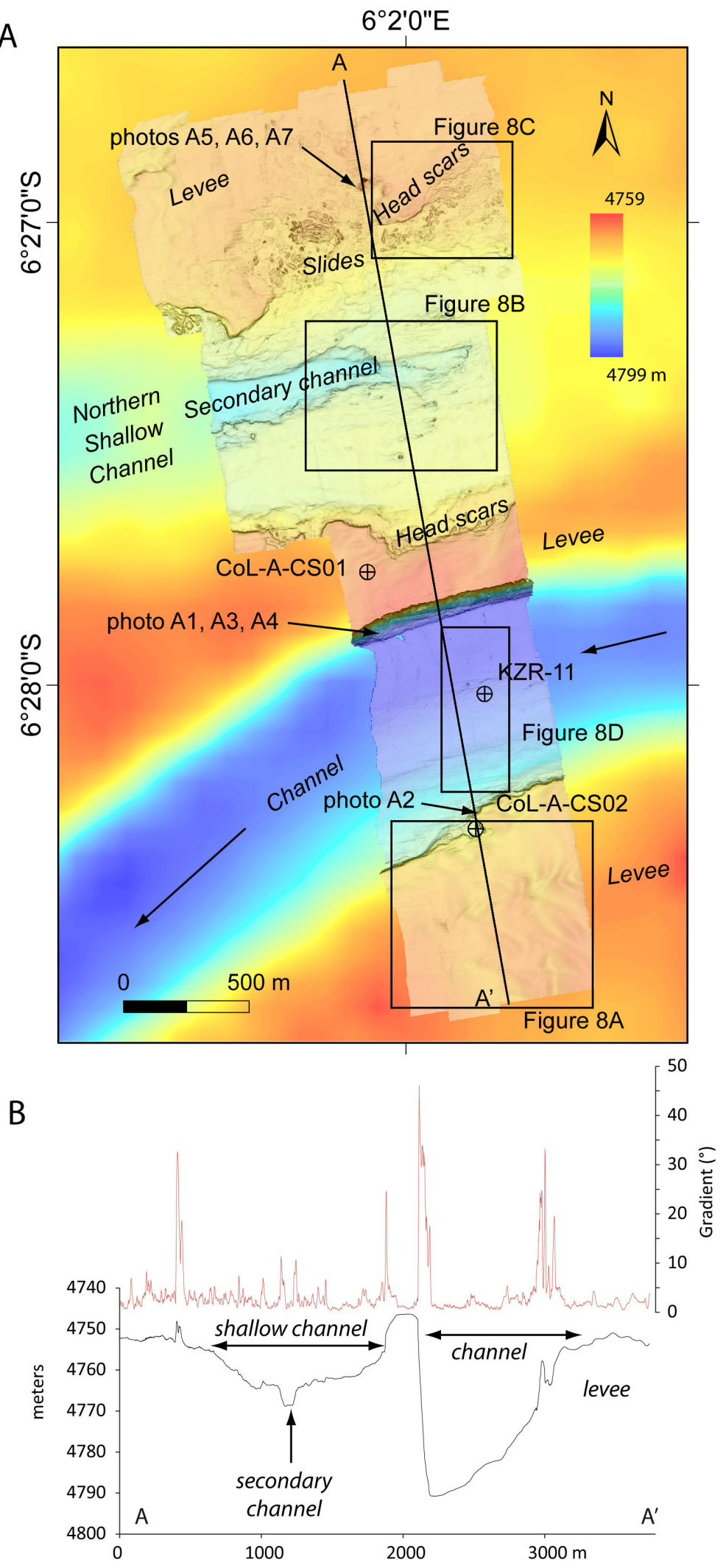

Figure 7: Morphological characteristics of site A (cf. location in Fig. 2). A: High-resolution bathymetric map. The grid is 1-m resolution. The area is located at the entrance of the lobe complex. Location of sediment cores, bathymetry close up views and seabed photos are indicated. Channel downstream is to the SW (arrows). B: Bathymetric (black) and gradient (red) profiles A-A' (location in A) across the feeding channel. 

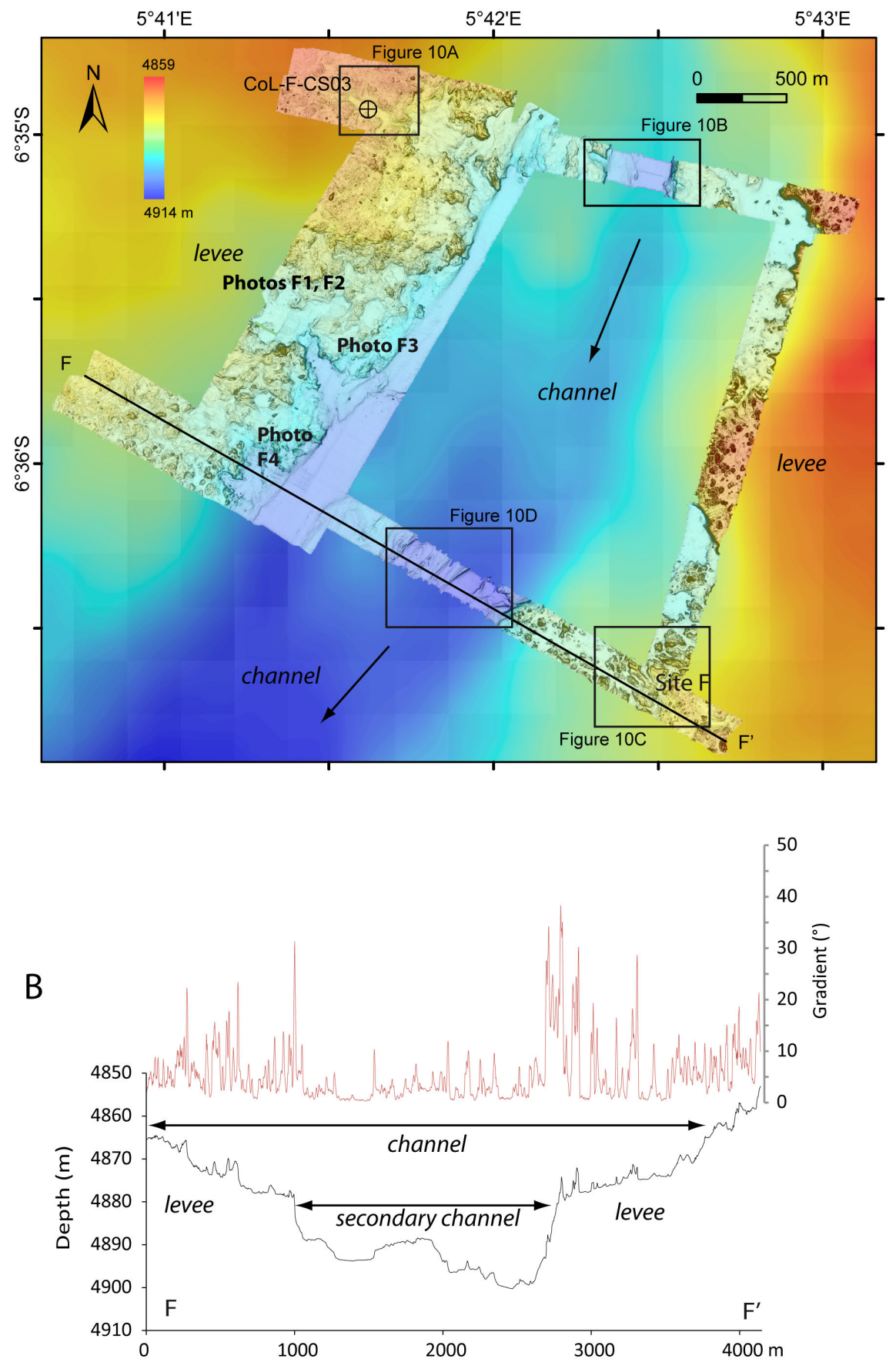

Figure 8: Close up views of morphological features at site A. Location of views is indicated in Fig. 7. A: Sediment waves on the southern levee of the feeding channel, and bathymetric profiles across the sediment waves (A-A1 and A1-A1'). B: Sediment waves (dash lines) and scour (obstacle) marks (in front of arrows) near the channel head North of site $A$, and bathymetric profiles across the sediment waves (A2-A2') and scours (A3-A3'). C: Slide North of site A, showing well-expressed headscars (dashed line) and block avalanche. D: Morphology of the feeding channel seafloor at site A and bathymetric profiles across the channel axis (A4$\left.A 4^{\prime}\right)$ and along the southern flank of the channel (A5-A5'). 
A
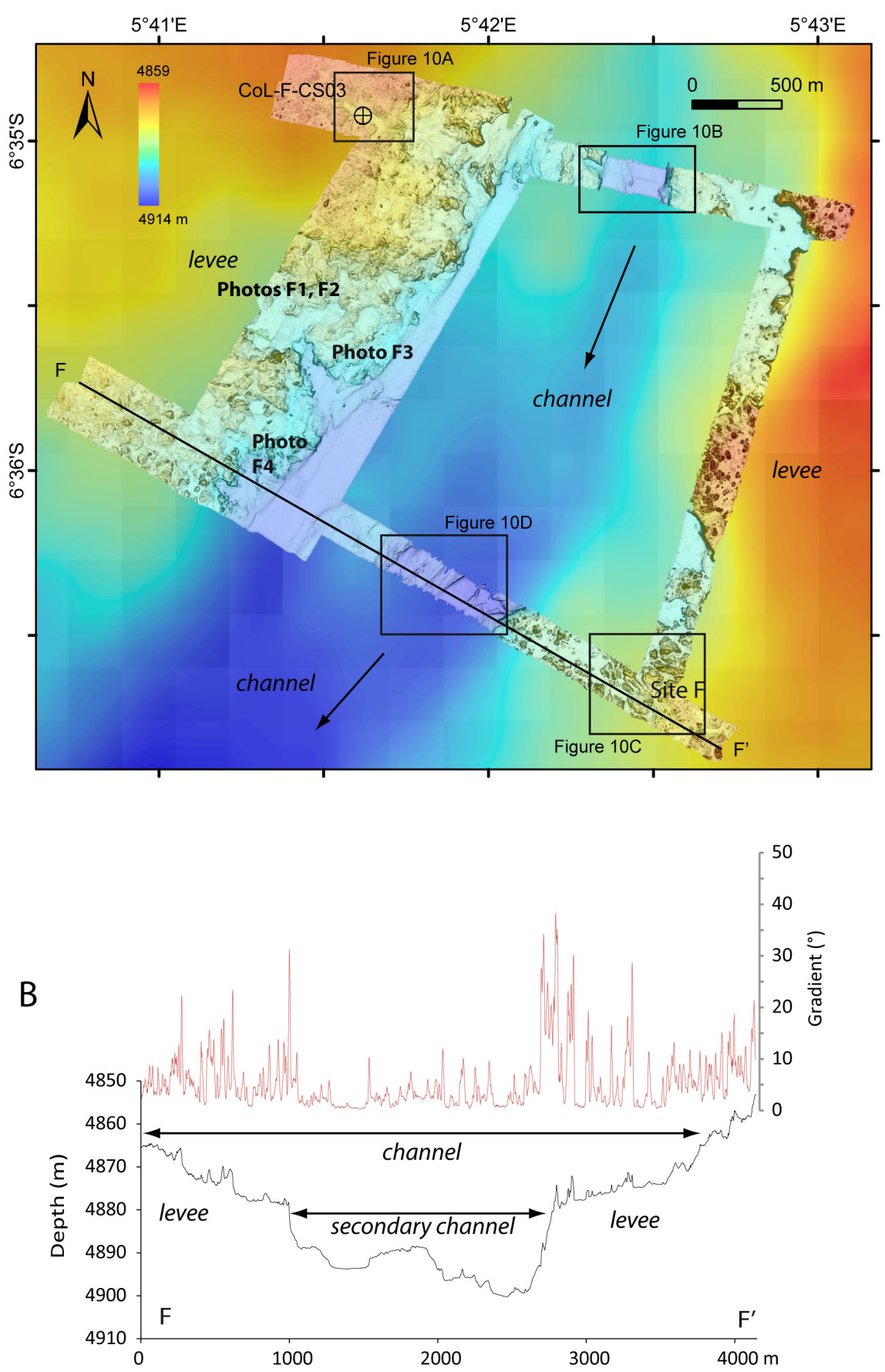

Figure 9: Morphological characteristics of site F (cf. location in Fig. 2). A: High-resolution bathymetric map. The grid is 1-m resolution. The area is located in the middle of the lobe complex. Location of sediment cores, bathymetry close up views as well as seabed photos are indicated. Channel downstream is to the SW (arrows). B: Bathymetric (black) and gradient (red) profiles F-F' (location in A) across the feeding channel. 

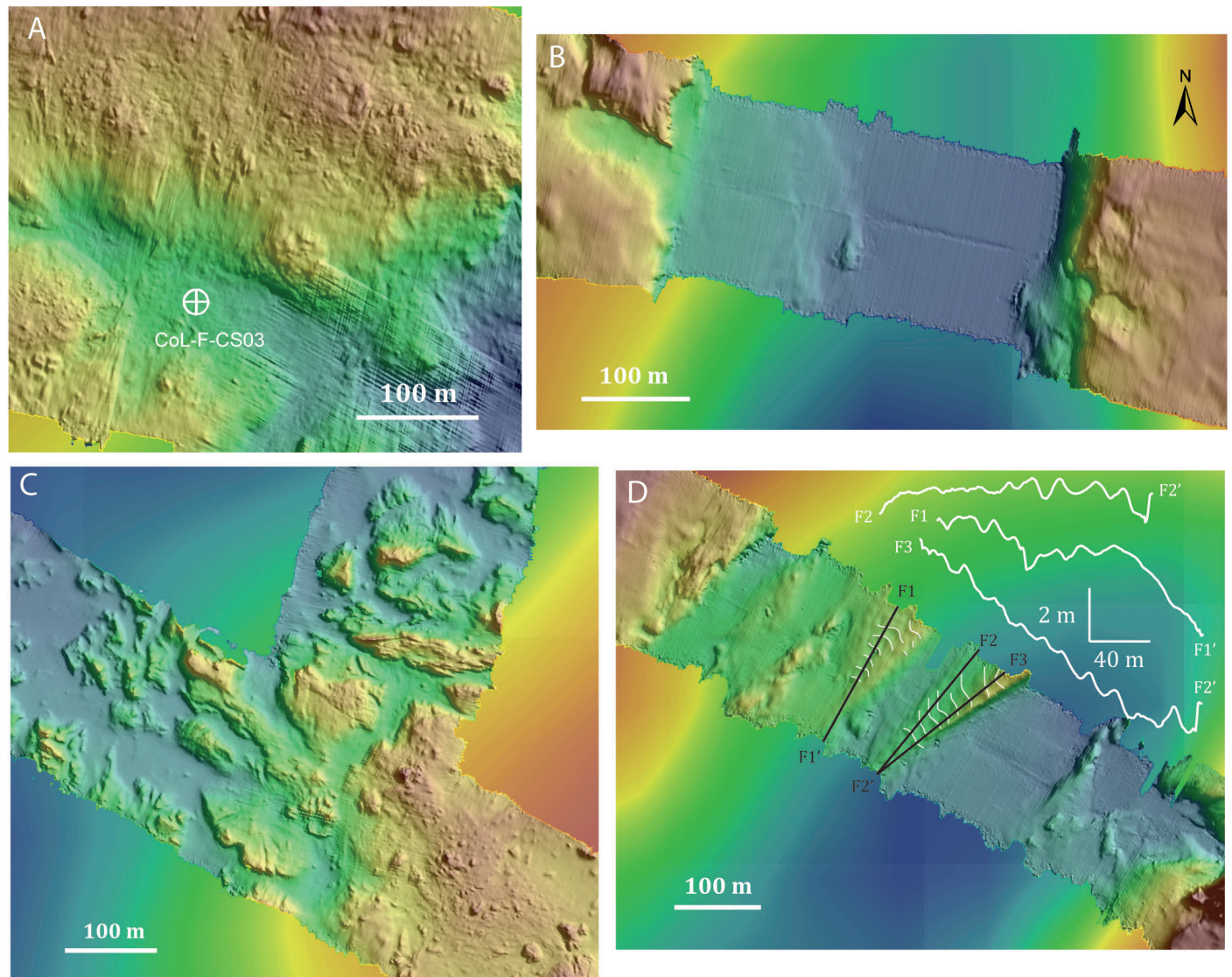

Figure 10: Close up views of morphological features at site F. Location of views is indicated in Fig. 9. A: Rough morphology interpreted as a field of buried blocks. B: Upstream view of the channel. C: Blocks on the SE side of the channel. D: Downstream view of the channel, see also the bathymetric profiles (F1-F1', F2-F2', F3-F2') across the dunes. 


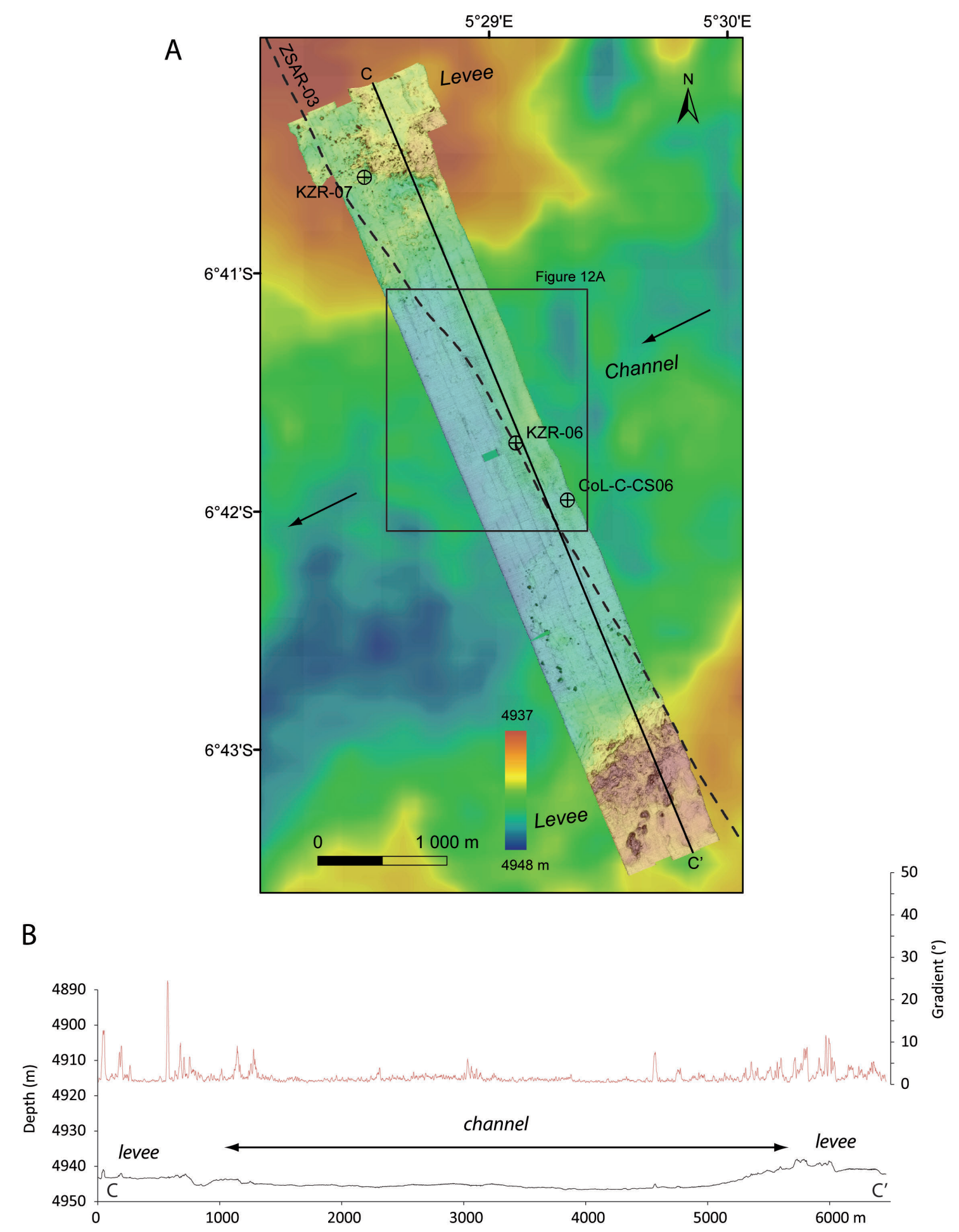

Figure 11: Morphological characteristics of site C (cf. location in Fig. 2). A: High-resolution bathymetric map. The grid is 1-m resolution. The area is located at the mouth of the feeding channel where the most distal lobe develops. Location of sediment cores, bathymetry close up views as well as seabed photos are indicated. B: Bathymetric (black) and gradient (red) profiles $C$ - $C^{\prime}$ (location in A) across the feeding channel. 

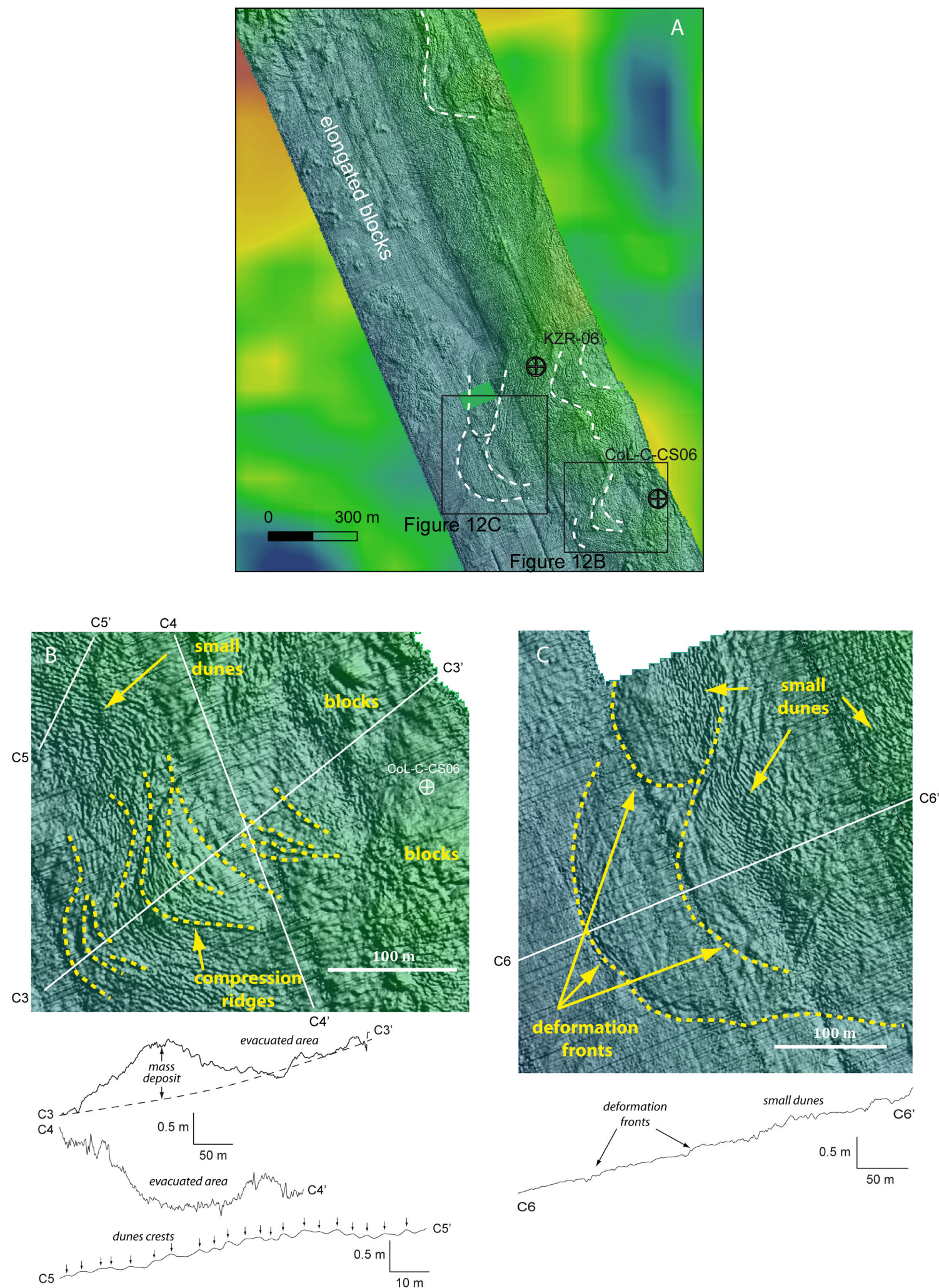

c6

Figure 12: Close up views of morphological features in the feeding channel at site C. Location of views is indicated in Fig. 11. A: Arcuate features are interpreted as indications of plastic deformation. B and C: Two close-up of slumps characterised by compression ridges (note also the occurrence of small dunes), and bathymetric profiles across (C3-C3' and C6-C6') and along (C4-C4') the slump and across the dunes (C5-C5'). 


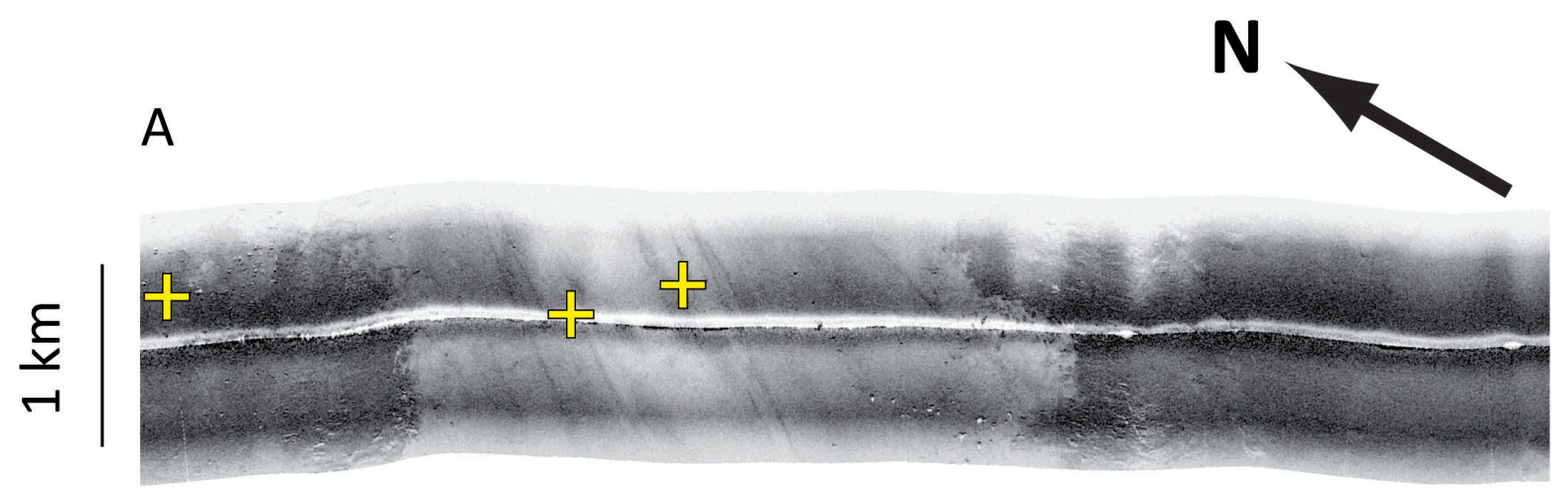

B
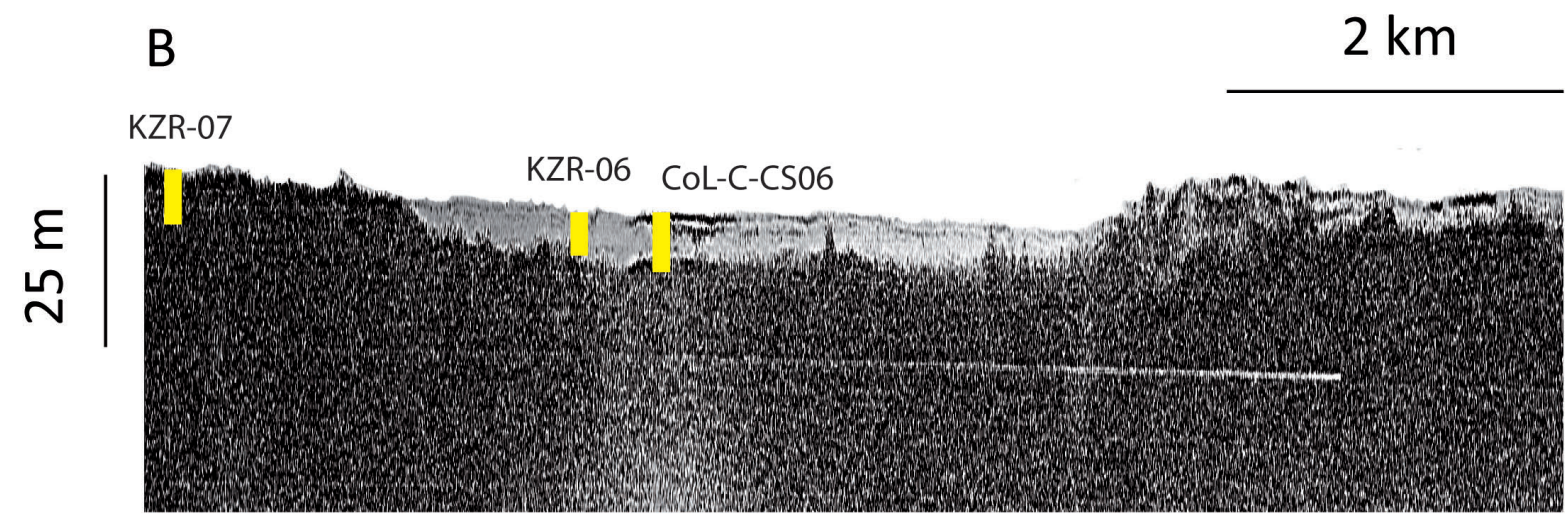

Figure 13: ZSAR-03 SAR side-scan sonar image (A) and $3.5 \mathrm{kHz}$ line (B) across the feeding channel at site C. Location is indicated as the dashed line in Fig. 11. See (1) low backscatter (light tone) and transparent echofacies in the channel, (2) high backscatter (dark tone) and high amplitude facies on the adjacent levees, (3) high amplitude facies at the base of the channel. The transparent $3.5 \mathrm{kHz}$ facies is interpreted as a sediment infill in the feeding channel. See also blocks on the levees on the side scan sonar image (A). See position of sediment cores. 

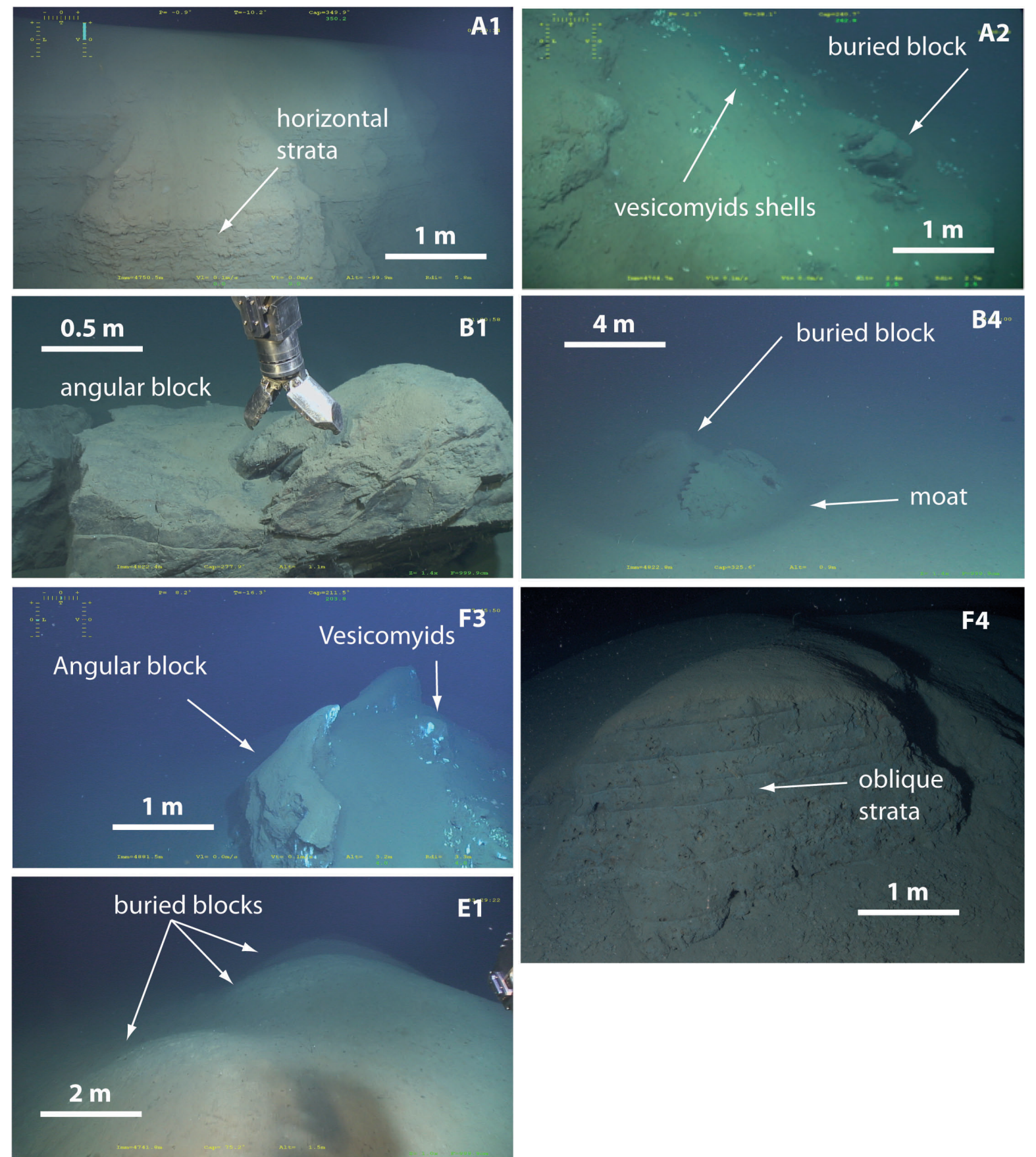

Figure 14: Selection of images acquired with the ROV at site A, B, E and F (cf. Fig. 2). Location of images is shown in Figs. 7 and 9. A1: Stratified muddy turbidites on the northern steep flank of the feeding channel. A2: Buried blocks near the top of the southern gentle flank, at the base of a headscar, interpreted as slumped deposits (see the vesicomyds aggregates nested near the blocks (cf. Sen et al. (this issue)). B1: Block with sharp angles; the ROV arm was able to break the block, showing that the sediment is soft. B4: buried block surrounded by a moat, indicative of erosion. F3: Buried block with still outcropping sharp angles. F4: Tilted block with slightly oblique stratification interpreted as fine-grained turbidites. E1: Gently undulating relief corresponding to buried blocks at an abandoned lobe complex to the north of the study area (Site E). See more images in supplementary material SM6, SM7 and SM8. 
A
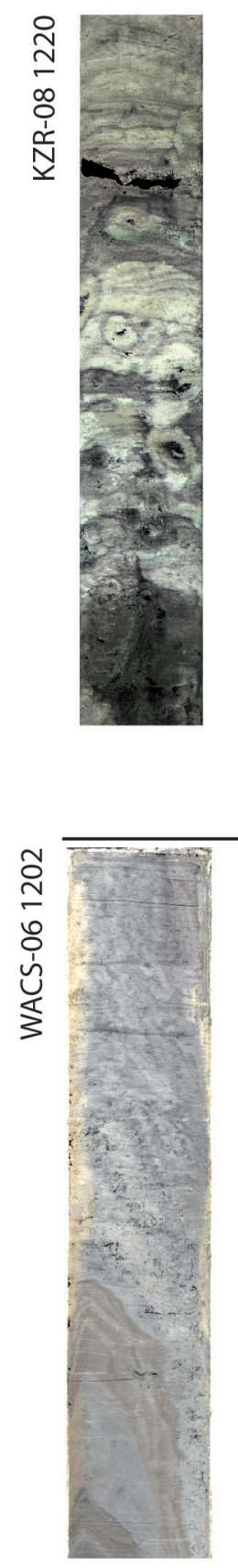

B

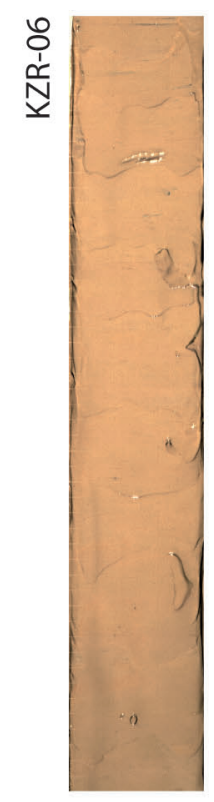

F

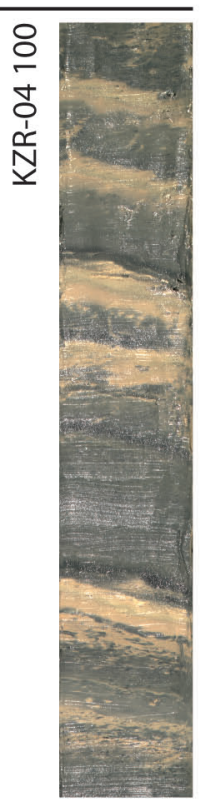

C

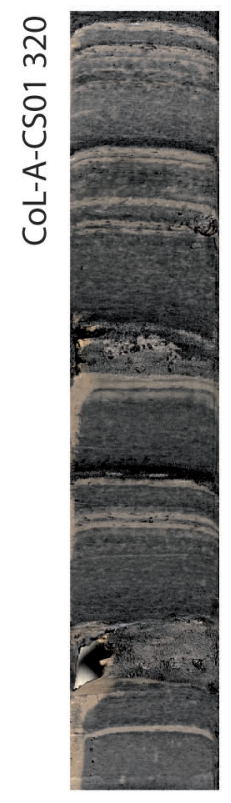

G

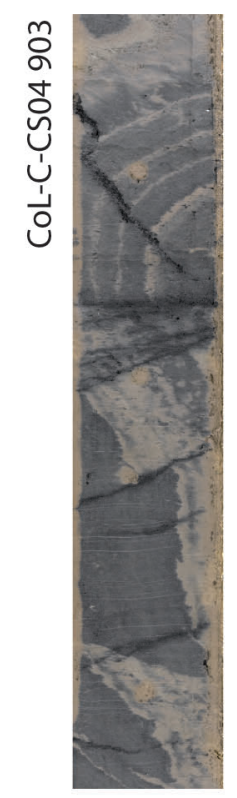

D

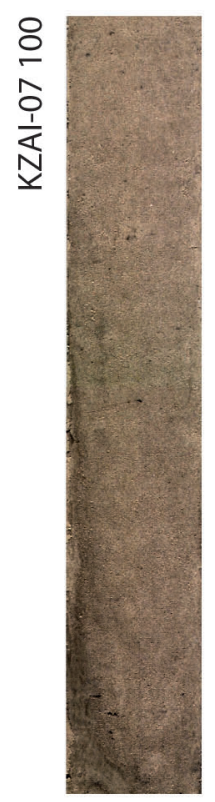

$\mathrm{H}$

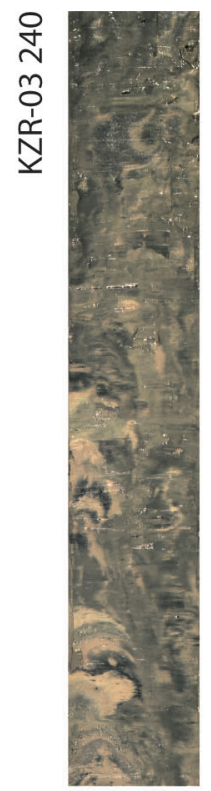

E

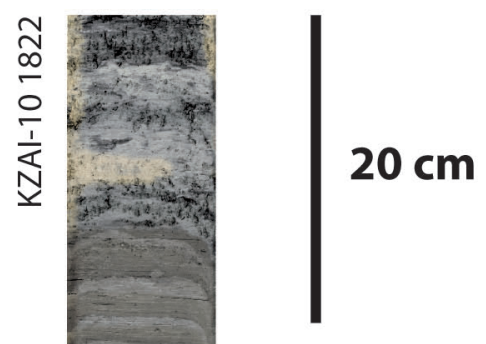

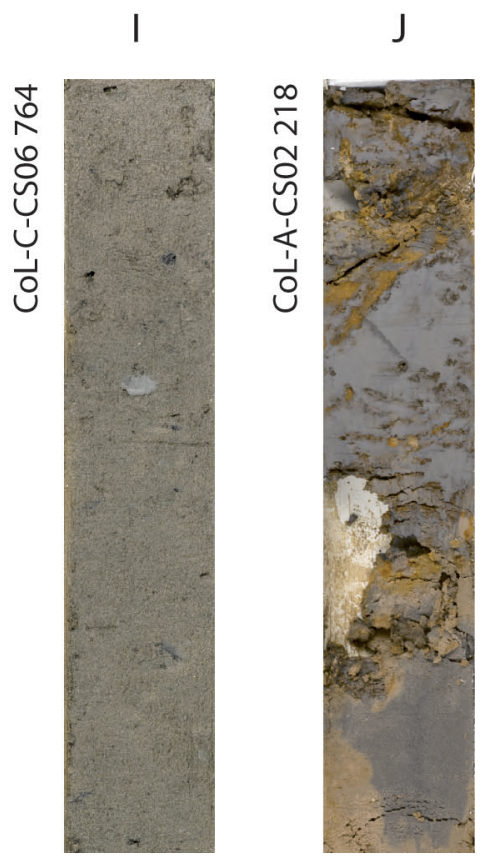

Figure 15: Photos showing the lithofacies recovered in the sediment cores at the Congo lobe complex. A: pelagic lithofacies composed of siliceous or carbonate pelagic ooze. B: turbidite structureless soft mud. C: turbidite laminated mud and silt. D: turbidite clean sand and silt. E: alternating muddy turbidites and pelagic ooze. F and G: folded or faulted muddy turbidite. H: muddy conglomerate or debrite, J: matrix dominant sandy debrite with few small mudclasts. J: clast dominant sandy debrite. See more photos of lithofacies in Supplementary Material SM9 and SM10. The number after the core name indicates the depth in core (cm) of the top of the photos. 


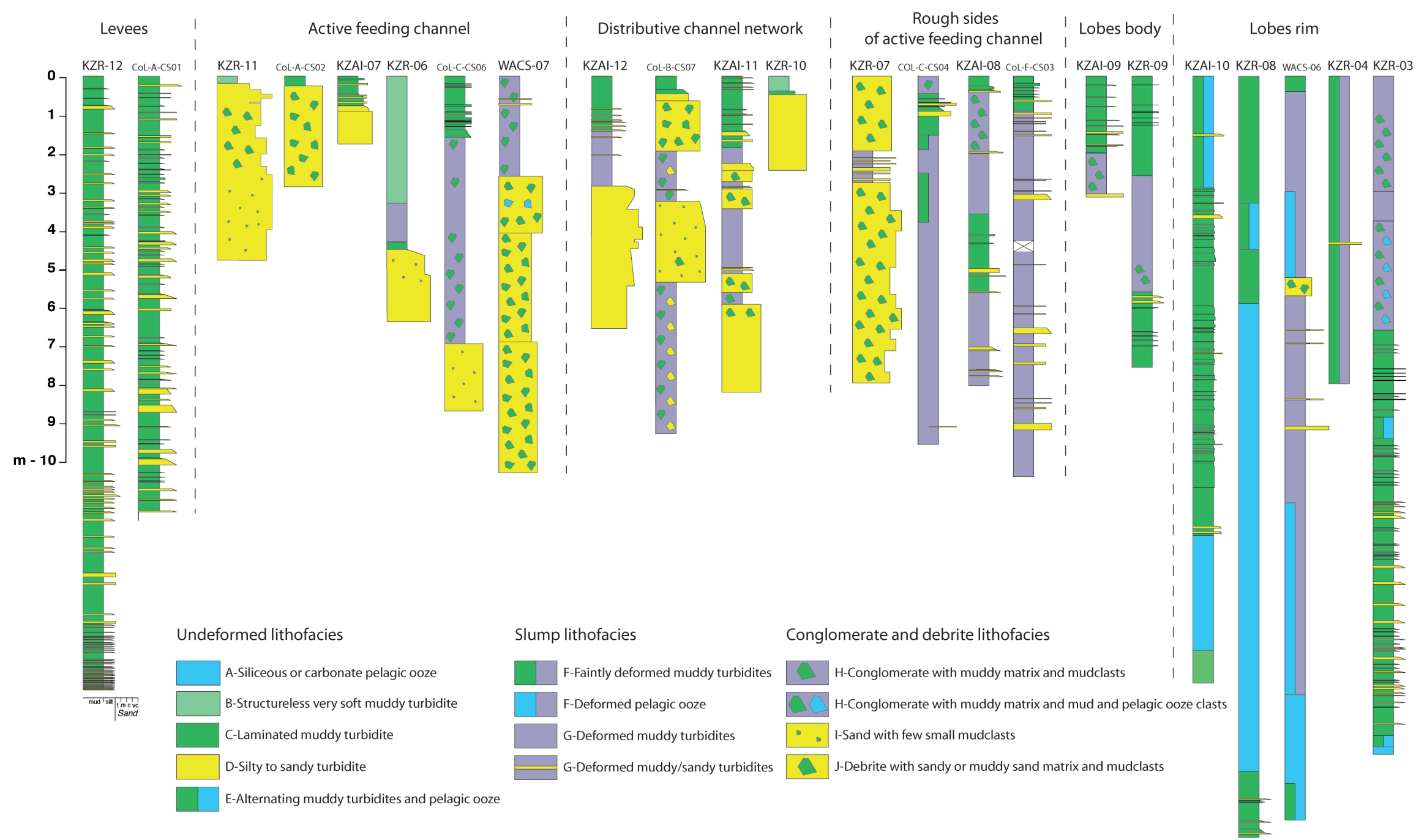

Figure 16: Summary logs of the lithofacies recovered at the Congo lobe complex. Location of cores is indicated in Figs. 2, 4, , 7, 8, 9, 10, 11 12 and 13, and in Supplementary Material SM4. 
A
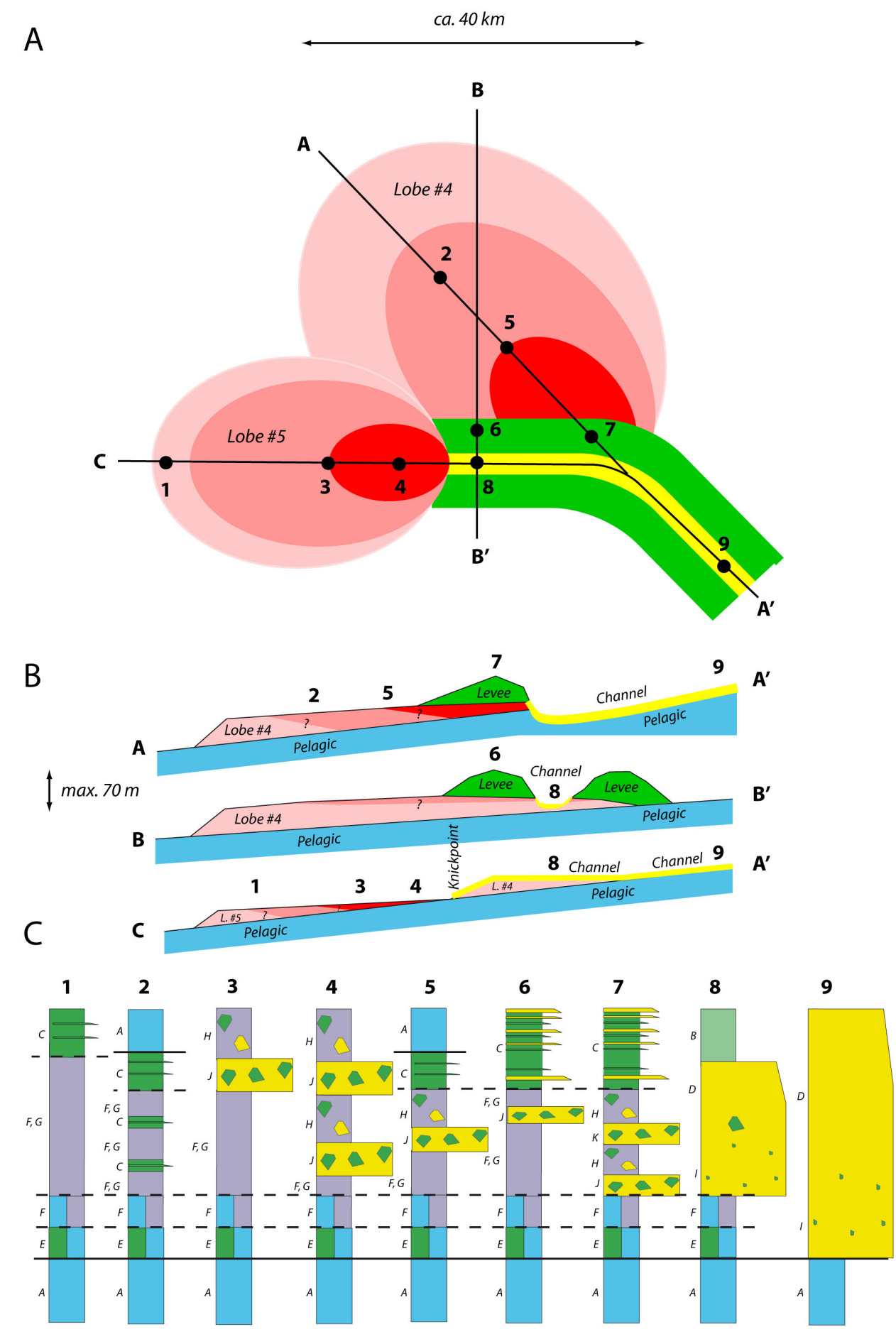

Conceptual lithostratigraphic logs, maximum thickness $70 \mathrm{~m}$ but not to scale.

Figure 17: Conceptual model of lithofacies repartition on the Congo lobe complex. A: plan view of two lobes representative of the initial (lobe \#4) and final (lobe \#5) phases of growth of a lobe. Lobe \#4 was abandoned after the shifting of the feeding channel. Lobe \#5 has developed at the mouth of the feeding channel. Red: area of the lobe where distributaries occur; medium pink: bodies of lobes; light pink: lobe rims; green: levees; yellow: channel. Black lines indicate location of the stratigraphic sections in B; black spots and numbers are the location of the conceptual lithostratigraphic successions. B: Conceptual stratigraphic sections across and along lobes (location in A); numbers correspond to lithostratigraphic logs in C. Note that the internal structure shown is speculative. C: Conceptual lithostratigraphic succession; plain lines indicate the boundary between the onset and the abandonment of a lobe that is marked by a contact between pelagic deposits and lobe deposits; dashed lines indicate boundaries between lithofacies in the lobe deposits; significance of patterns as in Fig. 16 and illustration of lithofacies in Fig. 15 and in Supplementary Material SM 9 and SM10. 
Tables

\begin{tabular}{|c|c|c|c|c|c|c|c|c|c|c|}
\hline \multirow[b]{2}{*}{ Cruises } & \multirow[b]{2}{*}{ Label } & \multirow[b]{2}{*}{$\begin{array}{c}\text { Speed } \\
\text { (kts) }\end{array}$} & \multicolumn{3}{|c|}{ Seismic configuration } & \multicolumn{2}{|c|}{ Sub-Bottom Profiler } & \multicolumn{3}{|c|}{ Multibeam Echo Sounder } \\
\hline & & & Source & Streamer & $\begin{array}{l}\text { Vertical } \\
\text { resolution } \\
(\mathrm{m})\end{array}$ & $\begin{array}{l}\text { Frequency } \\
\quad(\mathrm{kHz})\end{array}$ & $\begin{array}{c}\text { Vertical } \\
\text { resolution } \\
(\mathrm{m})\end{array}$ & $\begin{array}{c}\text { Type and } \\
\text { frequency } \\
(\mathrm{kHz}) \\
\end{array}$ & $\begin{array}{c}\text { Horizontal } \\
\text { resolution } \\
(\mathrm{m})\end{array}$ & $\begin{array}{c}\text { Vertical } \\
\text { resolution } \\
(\mathrm{m}) \\
\end{array}$ \\
\hline ZAÏANGO 1 & Z1-xx & $9-10$ & $\begin{array}{c}2 \text { GI guns } \\
\text { Shooting rate: } 11 \mathrm{~s}\end{array}$ & $\begin{array}{l}6 \text { channels } \\
\text { Sampling } \\
\text { rate: } 500 \mathrm{~Hz}\end{array}$ & $15-20$ & 3,5 & 0.30 & $\begin{array}{c}\text { Simrad EM12 } \\
13 \mathrm{kHz}\end{array}$ & & \\
\hline ZAÏANGO 2 & $\mathrm{Z} 2-\mathrm{xx}$ & 5 & $\begin{array}{l}4 \mathrm{GI}+2 \text { mini-GI guns } \\
\text { Shooting rate: } 10 \mathrm{~s}\end{array}$ & $\begin{array}{l}96 \text { channels } \\
\text { Sampling } \\
\text { rate: } 1 \mathrm{kHz}\end{array}$ & 10 & 3.5 & 0.30 & $\begin{array}{c}\text { Simrad EM12 } \\
13 \mathrm{kHz}\end{array}$ & 100 & water depth \\
\hline ZAÏANGOSAR & ZSAR & 2 & NA & NA & NA & 3.5 & 0.30 & NA & NA & NA \\
\hline
\end{tabular}

Table 1: Characteristics of geophysical acquisitions.

\begin{tabular}{ccccccc}
\cline { 2 - 6 } & Lobe 1 & Lobe 2 & Lobe 3 & Lobe 4 & Lobe 5 & $\begin{array}{c}\text { Lobe } \\
\text { complex }\end{array}$ \\
\hline $\begin{array}{c}\text { Surface } \\
\left(\mathrm{km}^{2}\right)\end{array}$ & 313 & 220 & 283 & 1203 & 506 & 2525 \\
\hline $\begin{array}{c}\text { Maximum thickness } \\
(\mathrm{m})\end{array}$ & 40 & 30 & 30 & 70 & 20 & $\sim 50$ \\
\hline
\end{tabular}

Table 2: Lobes and lobe complex dimensions. 


\begin{tabular}{|c|c|c|c|c|c|c|c|c|}
\hline & \multirow[t]{3}{*}{ Location } & \multirow[t]{3}{*}{$\begin{array}{c}\text { Average water } \\
\text { depth }(\mathrm{m})\end{array}$} & \multicolumn{6}{|c|}{ Channels } \\
\hline & & & & Shape & Flanks Gradients & & ize & Morphology \\
\hline & & & & & & Depth (m) & Width (m) & \\
\hline \multirow[b]{2}{*}{ Site A } & \multirow{2}{*}{$\begin{array}{l}30 \text { km downstream the } \\
\text { beginning of the lobe } \\
\text { complex (Figs. } 2,7 \text { ) } \\
\text { Entrance of the lobe } \\
\text { complex and lobe \#1 }\end{array}$} & \multirow[b]{2}{*}{4760} & $\begin{array}{l}\text { Active, } \\
\text { southern } \\
\text { feeding } \\
\text { channel }\end{array}$ & Asymmetric & $\begin{array}{c}\text { North. flank: } \leq \\
50^{\circ} \\
\text { South. flank: } \leq 10^{\circ}\end{array}$ & 45 & 1000 & $\begin{array}{l}\text { From E-W to NE-SW } \\
\left(45^{\circ} \text { bend }\right) \\
\text { Wavy southern levee }\end{array}$ \\
\hline & & & $\begin{array}{l}\text { Northern } \\
\text { secondary } \\
\text { channel }\end{array}$ & Symmetric & & 5 & 200 & $\begin{array}{c}\text { E-W, shallow } \\
\text { (previously connected } \\
\text { upstream to the feeding } \\
\text { channel) } \\
\text { Blocky northern levee }\end{array}$ \\
\hline \multirow[b]{2}{*}{ Site F } & \multirow[b]{2}{*}{$\begin{array}{l}40 \text { km dowstream from } \\
\text { Site A (Figs. 2, 9) } \\
\text { Entrance of lobe \# } 5\end{array}$} & \multirow[b]{2}{*}{4870} & $\begin{array}{l}\text { Main } \\
\text { channel }\end{array}$ & Symmetric & mean: $10^{\circ}$ & 40 & 4000 & $\begin{array}{c}\text { NE-SW } \\
\text { Blocky eastern and } \\
\text { western sides }\end{array}$ \\
\hline & & & $\begin{array}{l}\text { Internal } \\
\text { secondary } \\
\text { channel }\end{array}$ & Asymmetric & up to $35^{\circ}$ & $\begin{array}{l}\text { North: } 15 \\
\text { South: } 20\end{array}$ & $\begin{array}{l}\text { North: } 300 \\
\text { South: } 1800\end{array}$ & $\begin{array}{l}\text { NNE-SSW, flat and } \\
\text { smooth to the north } \\
\text { evolving southwards to } \\
\text { a complex, multi-axes } \\
\text { thalweg }\end{array}$ \\
\hline Site C & $\begin{array}{l}25 \mathrm{~km} \text { downstream from } \\
\text { Site F (Figs. 2, 11) } \\
\text { Termination of the feeder } \\
\text { channel of lobe \# } 5\end{array}$ & 4940 & $\begin{array}{l}\text { Channel } \\
\text { mouth }\end{array}$ & Symmetric & $<5^{\circ}$ & 8 & 5000 & $\begin{array}{l}\text { NE-SW, flat and wide } \\
\text { channel. } \\
\text { Blocky eastern and } \\
\text { western sides }\end{array}$ \\
\hline
\end{tabular}

Table 3: Morphological characteristics of channels at Sites A, F and C. 
Location

Site A,

Southern flank of the feeding channel

with gradient $>10^{\circ}$ (Fig. 7)

-Southern flank of the secondary channel

Headwalls

Site A,

Northern flank of the feeding channel (Fig.8C)
Shape

Semi-circular

$100 \mathrm{~m}$

Size

Associated features

Interpretation

No blocks on HR bathymetry

Draped boulders on ROV videos (Fig. 14, photo A2)

Slides or slump scars

longated blocks (ca.100 m) at the

headscarp base, evolving downslope to

squared to rounded blocks (ca.10 m)

ROV videos: partly buried, stratified

blocks (SM6, photo A7) forming elongated

hills (SM6, photos A5-A6)

\begin{tabular}{|c|c|c|c|c|c|}
\hline \multirow{5}{*}{$\begin{array}{l}\text { Block fields, } \\
\text { not } \\
\text { associated to } \\
\text { headscars }\end{array}$} & $\begin{array}{l}\text { Site F, channel eastern side } \\
\text { (Fig. 10C) } \\
\text { Blocks separated by flat areas }\end{array}$ & & $\begin{array}{l}\text { Decametric } \\
\text { to } \\
\text { hectometric }\end{array}$ & & $\begin{array}{l}\text { Flat areas between } \\
\text { blocks suggest infilling } \\
\text { by fluid sediment flows }\end{array}$ \\
\hline & $\begin{array}{l}\text { Site A, near the head of the secondary } \\
\text { channel (Fig. 8B), partly buried }\end{array}$ & & $\leq 10 \mathrm{~m}$ & Dune and scour marks field & $\begin{array}{l}\text { Partial burying by } \\
\text { bottom currents }\end{array}$ \\
\hline & $\begin{array}{l}\text { Site A, partly buried blocks in the } \\
\text { feeding channel (Fig. 8D) }\end{array}$ & \multicolumn{2}{|r|}{ Metric } & & $\begin{array}{l}\text { Maybe transported by } \\
\text { currents }\end{array}$ \\
\hline & $\begin{array}{l}\text { Site A, trains of blocks at the base of } \\
\text { the northern outer flank of the } \\
\text { feeding channel } \\
\text { (SM6, photo A4) }\end{array}$ & & \multirow{2}{*}{$\begin{array}{l}\text { Centimetric } \\
\text { to } \\
\text { decimetric }\end{array}$} & $\begin{array}{l}\text { Downslope of the very abrupt channel- } \\
\text { levee transition showing stratified freshly } \\
\text { exposed sediments and steps } \\
\text { (SM6, photo A3) }\end{array}$ & Recent erosion \\
\hline & $\begin{array}{l}\text { Sites F and C: rough morphology of } \\
\text { the channel sides (Figs. } 9 \text { and 11) }\end{array}$ & & & $\begin{array}{l}\text { Stratified facies with decimetric strata } \\
\text { (Fig. 14, photos F3-F4; SM8, photos F1-F 2) }\end{array}$ & Turbidite lithofacies \\
\hline \multirow{2}{*}{$\begin{array}{c}\text { Fluid, } \\
\text { plastic } \\
\text { deformations }\end{array}$} & \multirow[t]{2}{*}{$\begin{array}{l}\text { Site C, channel seabed } \\
\text { (Fig. 12A) }\end{array}$} & $\begin{array}{l}\text { Bulges with fan- } \\
\text { shaped } \\
\text { morphologies on dip } \\
\text { sections } \\
\end{array}$ & Relief: $0.7 \mathrm{~m}$ & \multirow{2}{*}{$\begin{array}{l}\text { Outlined by arcuate ridges of } 5-10 \mathrm{~m} \\
\text { amplitude (Figs. } 12 B, 12 C \text { ) } \\
\text { Possible superimposition of dunes of } \\
\text { metric wavelength and centimetric } \\
\text { amplitude (Figs. } 12 B, 12 C \text { ) }\end{array}$} & \multirow[t]{2}{*}{ Small-scale slumps } \\
\hline & & $\begin{array}{l}\text { Depressions on } \\
\text { strike sections }\end{array}$ & $\begin{array}{l}\text { Relief: } \\
0,5 \text { to } 1 \mathrm{~m}\end{array}$ & & \\
\hline
\end{tabular}

Table 4: Main characteristics of mass wasting features. 


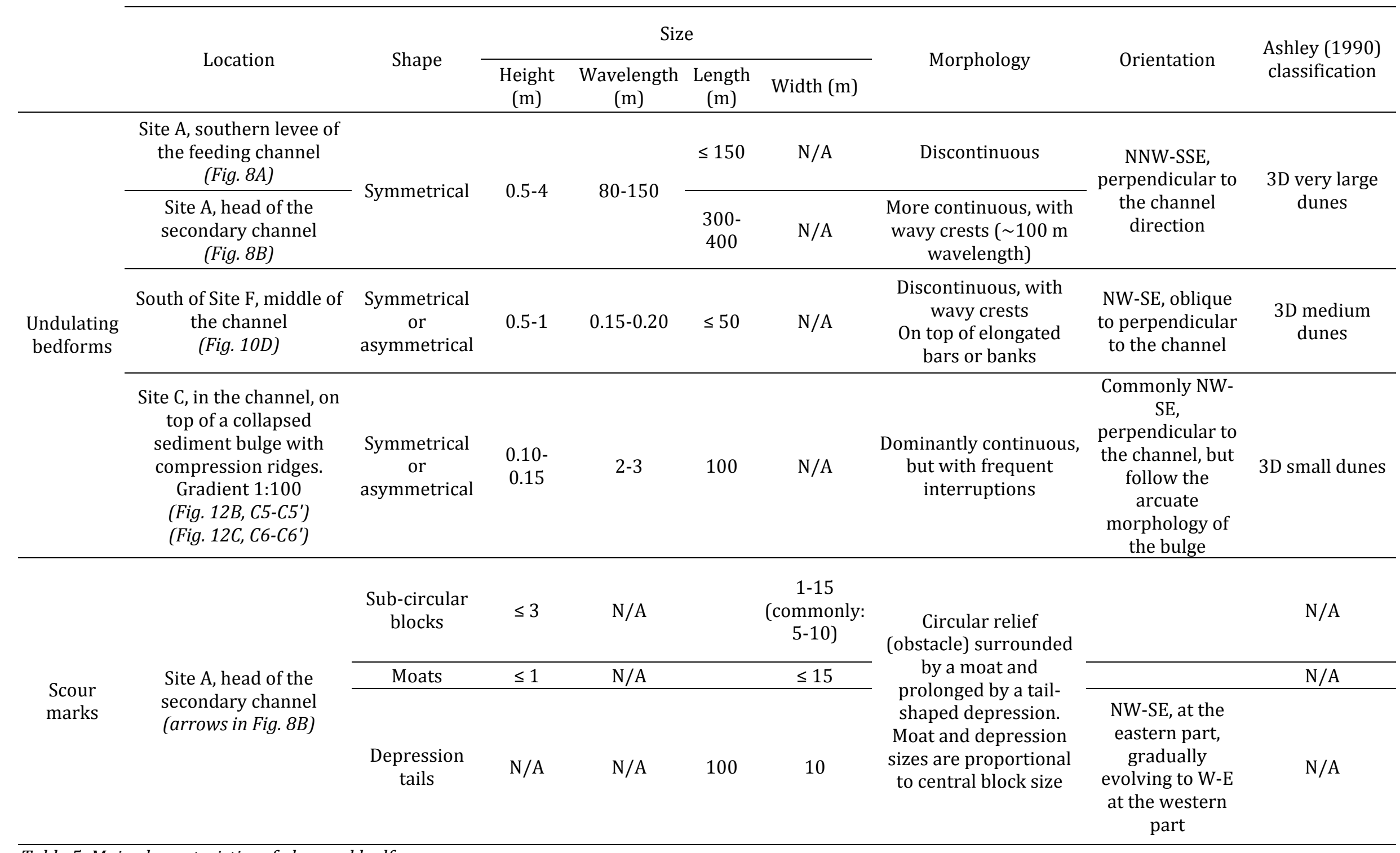

Table 5: Main characteristics of observed bedforms. 


\begin{tabular}{|c|c|c|c|c|c|c|c|}
\hline & & Type & Composition & Colour & Grain size & Structures, features & $\begin{array}{l}\text { Sedimentary } \\
\text { processes }\end{array}$ \\
\hline \multirow{4}{*}{ 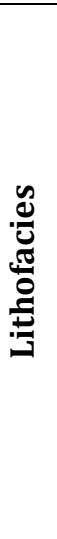 } & Type A & Pelagic, Te (Bouma) & $\begin{array}{l}\text { Clay, calcareous } \\
\text { nannofossils, } \\
\text { foraminifera, } \\
\text { radiolarian, diatoms }\end{array}$ & $\begin{array}{l}\text { Pale olive }(5 \mathrm{Y} \\
6 / 3), \text { greenish } \\
(5 \mathrm{G} 6 / 1) \text {, olive } \\
(5 \mathrm{Y} 4 / 1)\end{array}$ & Clay to silt & $\begin{array}{l}\text { Burrows with concentric } \\
\text { chemical fronts }\end{array}$ & $\begin{array}{l}\text { Pelagic decantation, } \\
\text { low sedimentation } \\
\text { rates }\left(1-2 \mathrm{~cm} / \mathrm{ka}^{-1}\right)\end{array}$ \\
\hline & Type B & $\begin{array}{l}\text { Turbiditic structureless } \\
\text { soft mud, Td-Te (base } \\
\text { cut-out Bouma) }\end{array}$ & $\begin{array}{c}\text { Clay, quartz, vegetal } \\
\text { debris }\end{array}$ & Dark brown & $\begin{array}{l}\text { Median : } \\
7-35 \mu \mathrm{m}\end{array}$ & $\begin{array}{l}\text { Normal gradding over several } \\
\text { metres }\end{array}$ & $\begin{array}{l}\text { Sediment laden } \\
\text { turbidity currents }\end{array}$ \\
\hline & Type C & $\begin{array}{l}\text { Turbiditic laminated } \\
\text { mud and silt, Tc to Td } \\
\text { (Bouma) }\end{array}$ & $\begin{array}{c}\text { Clay, quartz, vegetal } \\
\text { debris }\end{array}$ & $\begin{array}{c}\text { Brownish grey } \\
\text { to dark } \\
\text { brownish } \\
\end{array}$ & $\begin{array}{l}\text { Clay to } \\
\text { silt, little } \\
\text { sand } \\
\end{array}$ & $\begin{array}{l}\text { Alternating layers of mud and } \\
\text { silt, } 1 \text { to } 20 \mathrm{~cm} \text { thick }\end{array}$ & $\begin{array}{l}\text { Sediment laden } \\
\text { turbidity currents }\end{array}$ \\
\hline & Type D & $\begin{array}{l}\text { Turbiditic clean sand, } \\
\text { Ta (Bouma) }\end{array}$ & $\begin{array}{l}\text { Quartz, micas, vegetal } \\
\text { debris }\end{array}$ & Grey & $\begin{array}{c}\text { Fine to } \\
\text { coarse } \\
\text { sand } \\
\end{array}$ & 1 to $3 \mathrm{~m}$ thick layers & $\begin{array}{l}\text { Base of sediment laden } \\
\text { turbidity currents }\end{array}$ \\
\hline \multirow{6}{*}{ 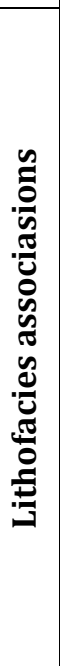 } & Type E & $\begin{array}{l}\text { Alternating turbidites } \\
\text { and pelagic }\end{array}$ & \multicolumn{3}{|c|}{ Lithofacies type A and C } & $\begin{array}{c}\text { Horizontal strata no } \\
\text { deformation }\end{array}$ & $\begin{array}{l}\text { Alternating pelagic and } \\
\text { turbiditic processes }\end{array}$ \\
\hline & Type F & $\begin{array}{l}\text { Alternating turbidites } \\
\text { and pelagic }\end{array}$ & \multicolumn{3}{|c|}{ Lithofacies type $\mathrm{A}$ and $\mathrm{C}$} & $\begin{array}{l}\text { Folds, strata inclination } 5^{\circ} \text { to } \\
990^{\circ}\end{array}$ & Slump \\
\hline & Type G & $\begin{array}{l}\text { Alternating turbidites } \\
\text { and pelagic }\end{array}$ & \multicolumn{3}{|c|}{ Lithofacies type $\mathrm{A}$ and $\mathrm{C}$} & $\begin{array}{l}\text { Folds and faults, strata } \\
\text { inclination } 5^{\circ} \text { to } 90^{\circ}\end{array}$ & Slump, slide \\
\hline & Type H & $\begin{array}{l}\text { Muddy conglomerate or } \\
\text { debrite }\end{array}$ & \multicolumn{3}{|c|}{ Lithofacies type A and C } & $\begin{array}{c}\text { Centimetric to decimetric } \\
\text { mudclasts }(90 \%), \\
\text { muddy matrix }(10 \%)\end{array}$ & Debris flow \\
\hline & Type I & $\begin{array}{l}\text { Matrix dominant sandy } \\
\text { debrite }\end{array}$ & \multicolumn{3}{|c|}{ Lithofacies type A, C and D } & $\begin{array}{c}\text { Sharp or rounded } \\
\text { mudclasts }(10 \%) \\
\text { sandy matrix }(90 \%)\end{array}$ & $\begin{array}{l}\text { Concentrated or } \\
\text { hyperconcentrated } \\
\text { density flow }\end{array}$ \\
\hline & Type J & $\begin{array}{l}\text { Clast dominant sandy } \\
\text { debrite }\end{array}$ & \multicolumn{3}{|c|}{ Lithofacies type A, C and D } & $\begin{array}{l}\text { Centimetric to decimetric } \\
\text { mudclasts (50 to } 10 \% \text { ) with } \\
\text { sand injections into the clasts, } \\
\text { sandy matrix ( } 50 \% \text { to } 90 \%)\end{array}$ & Slide or debris flow \\
\hline
\end{tabular}

Table 6: Description of lithofacies and lithofacies associations in the Congo channel-mouth lobe complex. See photos of lithofacies in Fig. 15, SM9 and SM10. 


\section{Supplementary material}

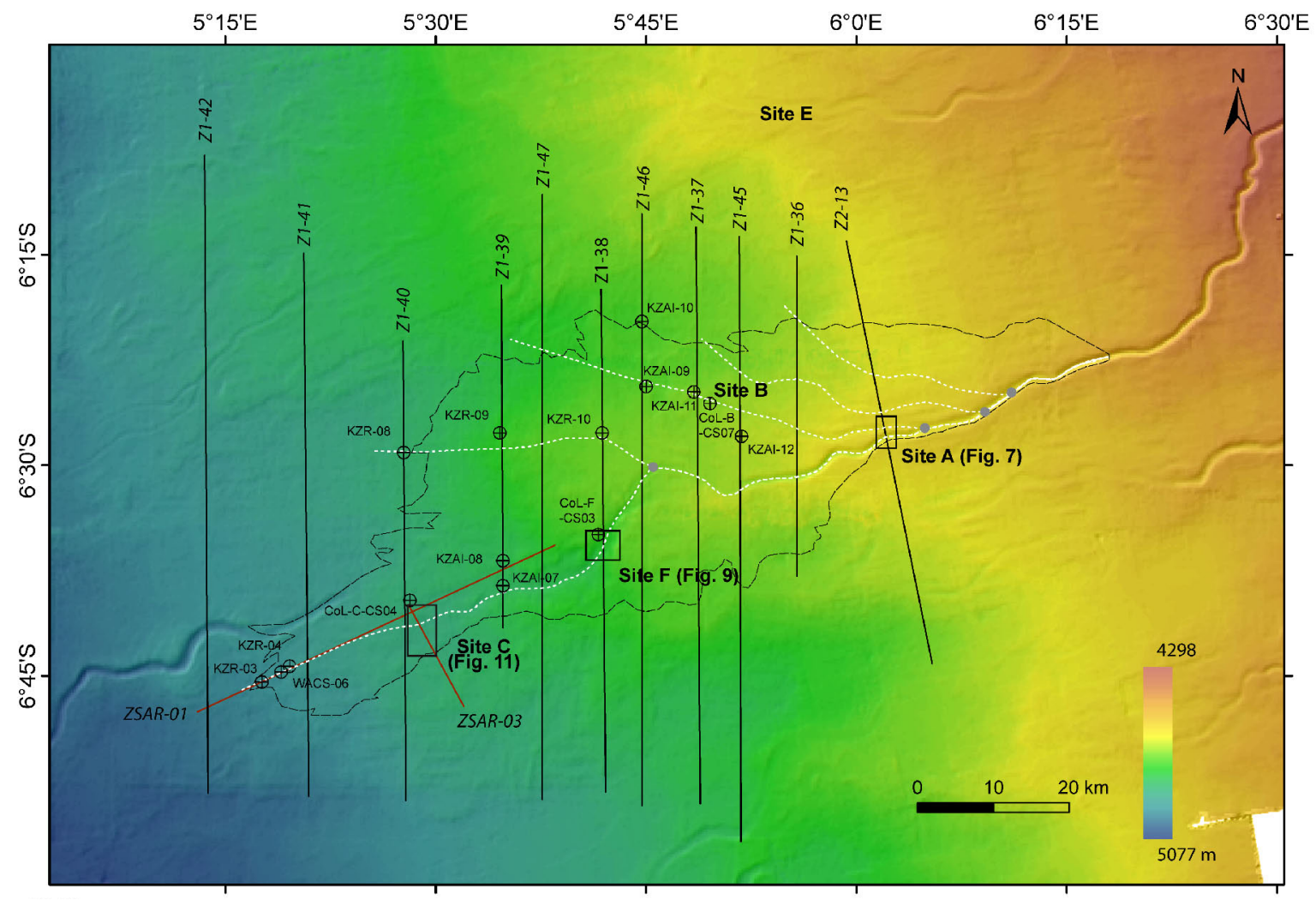

SM1: EM12 bathymetric map of the study area (same as Fig. 2) with location of seismic and chirp lines shown on SM3 and SM4. 


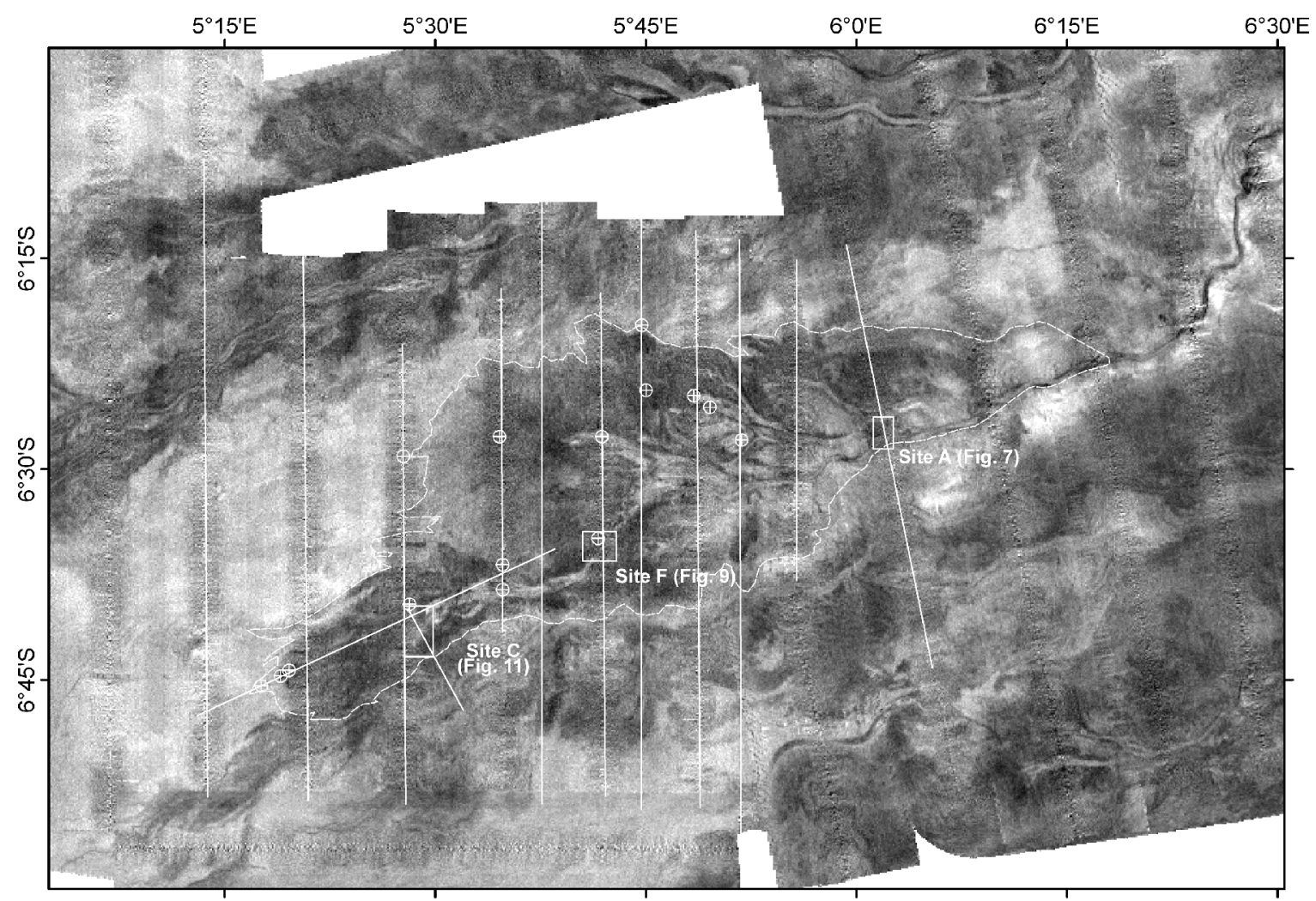

SM2: EM12 acoustic backscatter map of the study area (same as Fig. 3) with location of seismic and chirp lines shown on SM3 and SM4. 


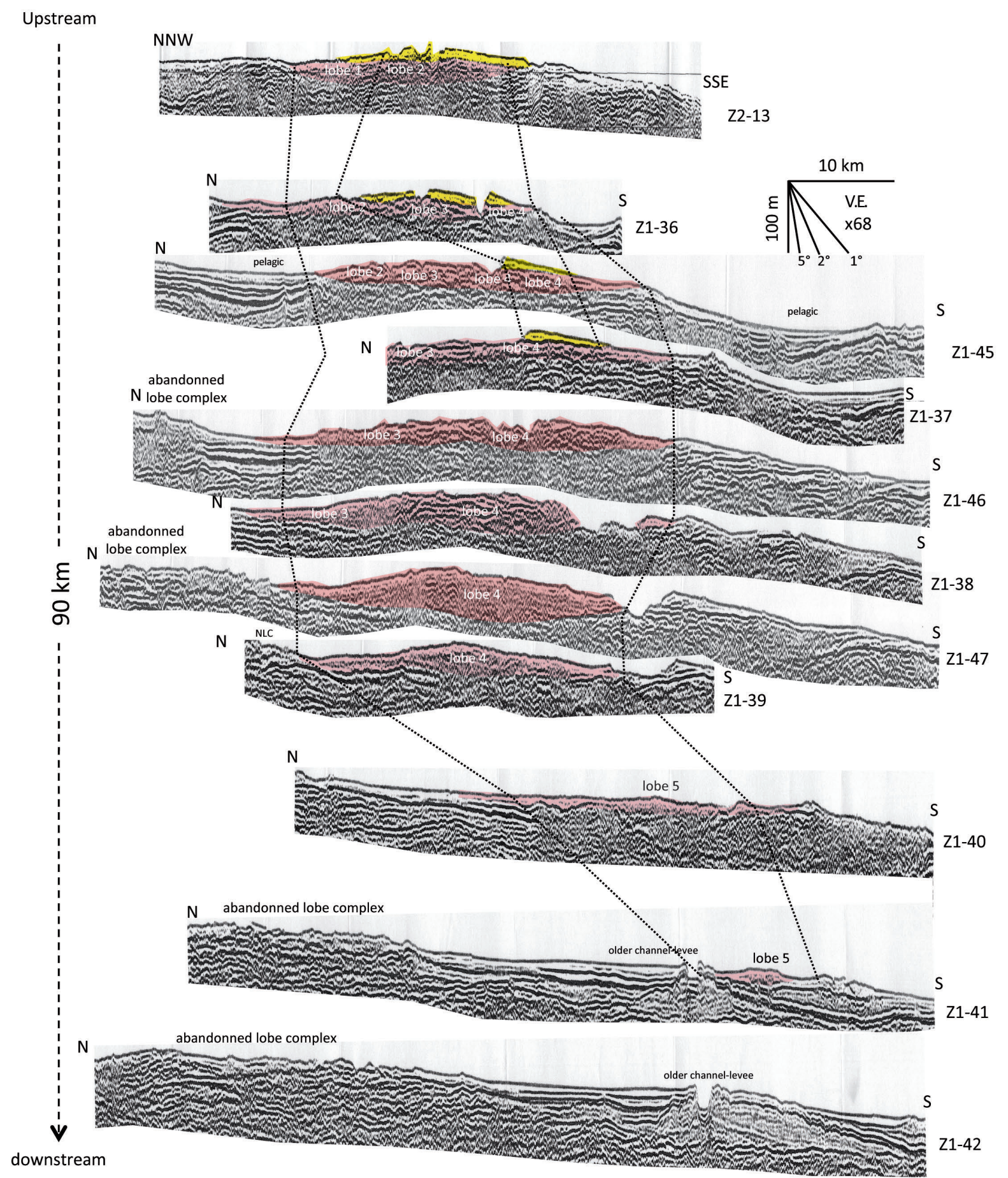

SM3: Location of seismic lines on the Congo lobe complex. Yellow: levees; pink: lobe. The dashed line indicates the boundaries of the Congo lobe complex as indicated on Figs. 2, 3 and 5. 


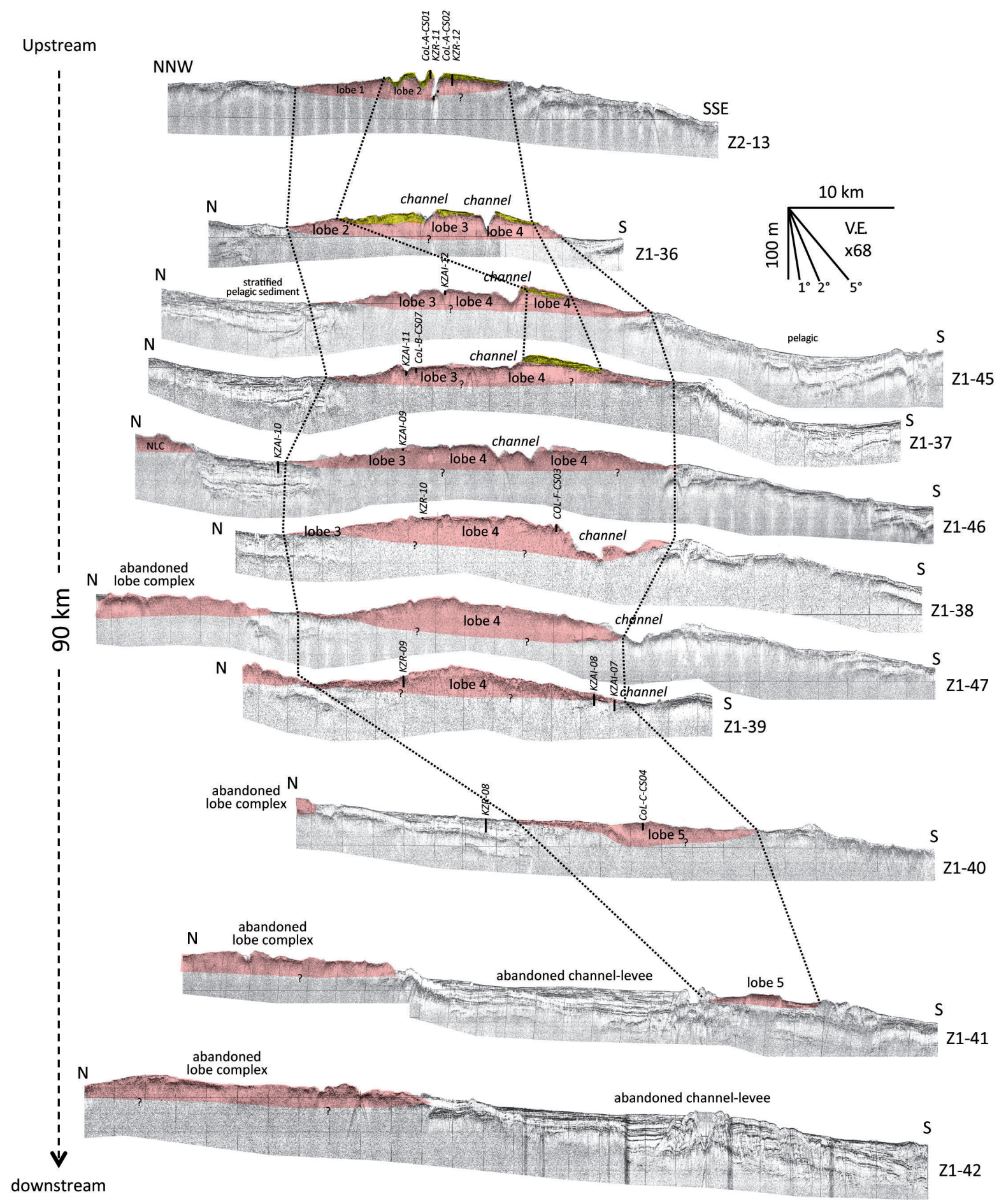

SM4: Location of $3.5 \mathrm{kHz}$ lines on the Congo lobe complex. Yellow: levees; pink: lobe. The dashed line indicates the boundaries of the Congo lobe complex as indicated on Figs. 2, 3 and 5. 


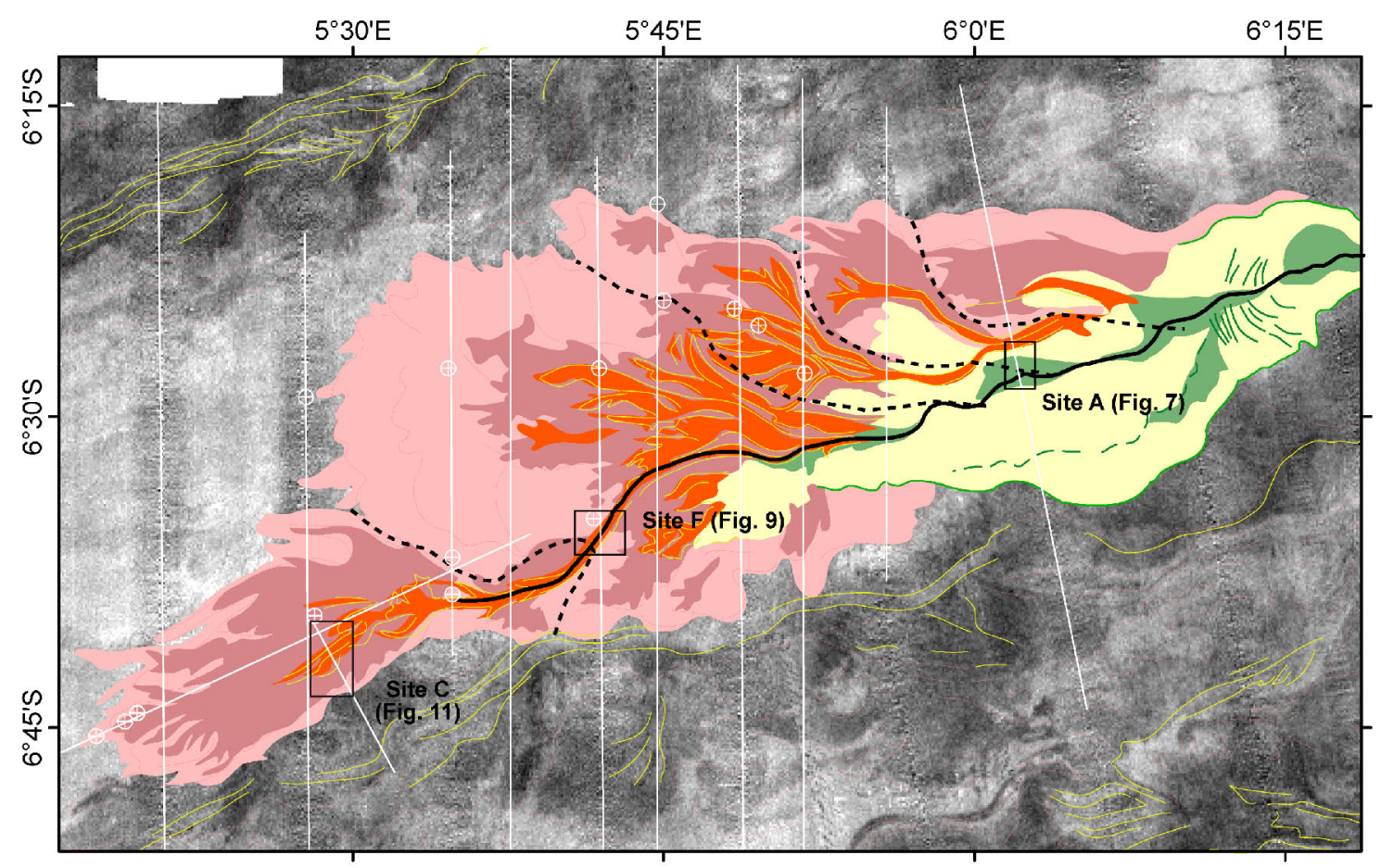

SM5: Interpretative map of the Congo lobe complex (same as Fig. 5) with location of seismic and chirp lines shown on SM3 and SM4. Feeding channel (black), lobes rim and body (pink), distributaries (red), levees on the side of the feeding channel (yellow). Dashed black lines indicate the limits between the lobes. The circled numbers are the lobe numbers. Note that lobes are numbered in the stratigraphic order, from upstream (oldest lobe \#1) to downstream (youngest lobe \#5). 

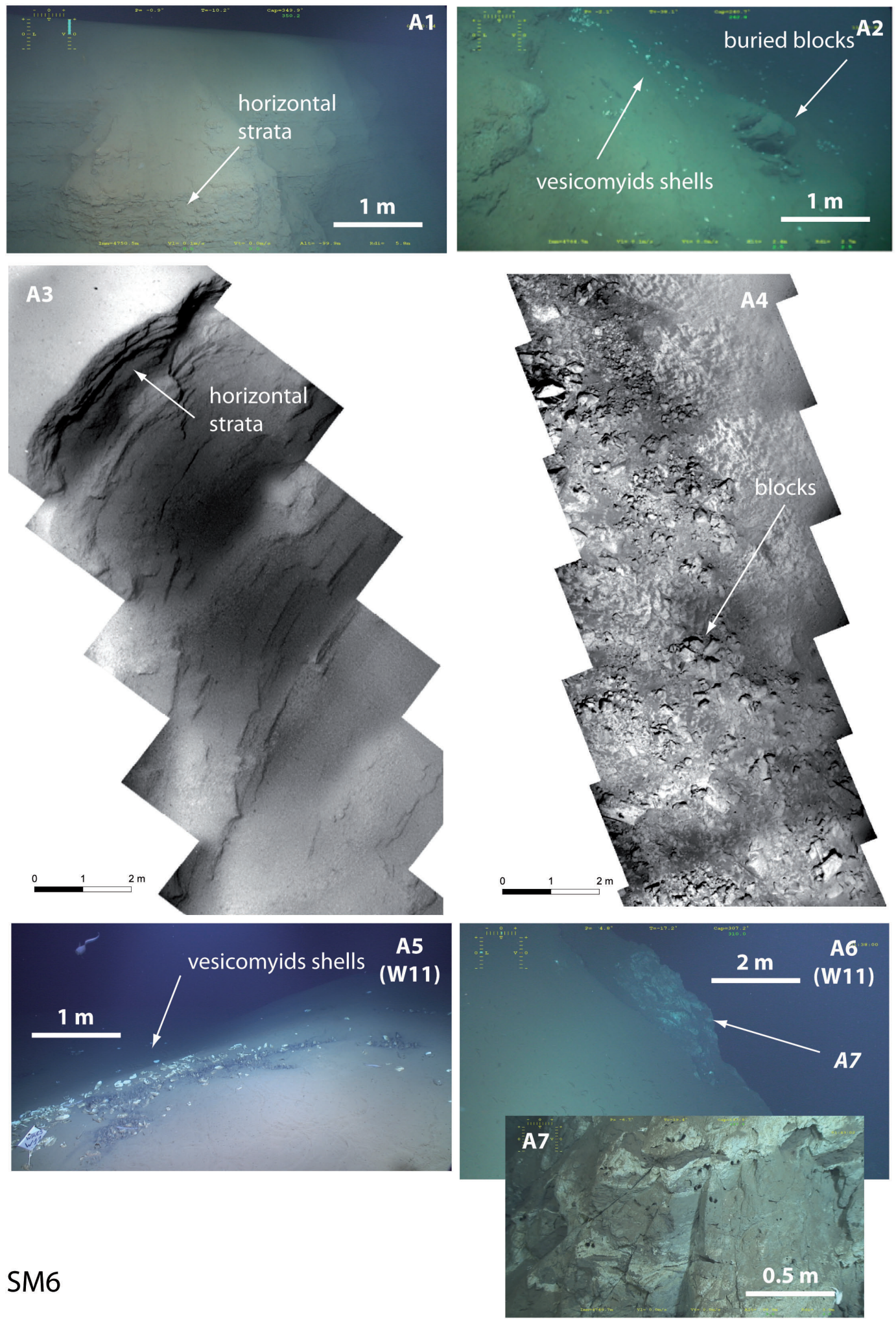

SM6: Seabed photos at site A (cf. Fig. 2). Location of images is shown in Fig. 7. A1 and A3: Stratified muddy turbidites on the northern steep flank of the feeding channel. A2: Buried blocks near the top of the southern gentle flank, at the base of a headscar, interpreted as slumped deposits (see the vesicomyds aggregates nested near the blocks (cf. Sen et al. (this issue)). A4: Train of decimetric blocs at the base of the northern steep flank. A5 and A6: Buried blocks on the northern part of site A, near a slide headscar (see black patches of reduced sediment and vesicomyds shells). A7: Close-up view of A6, showing sharp angles and stratifications on a block. 

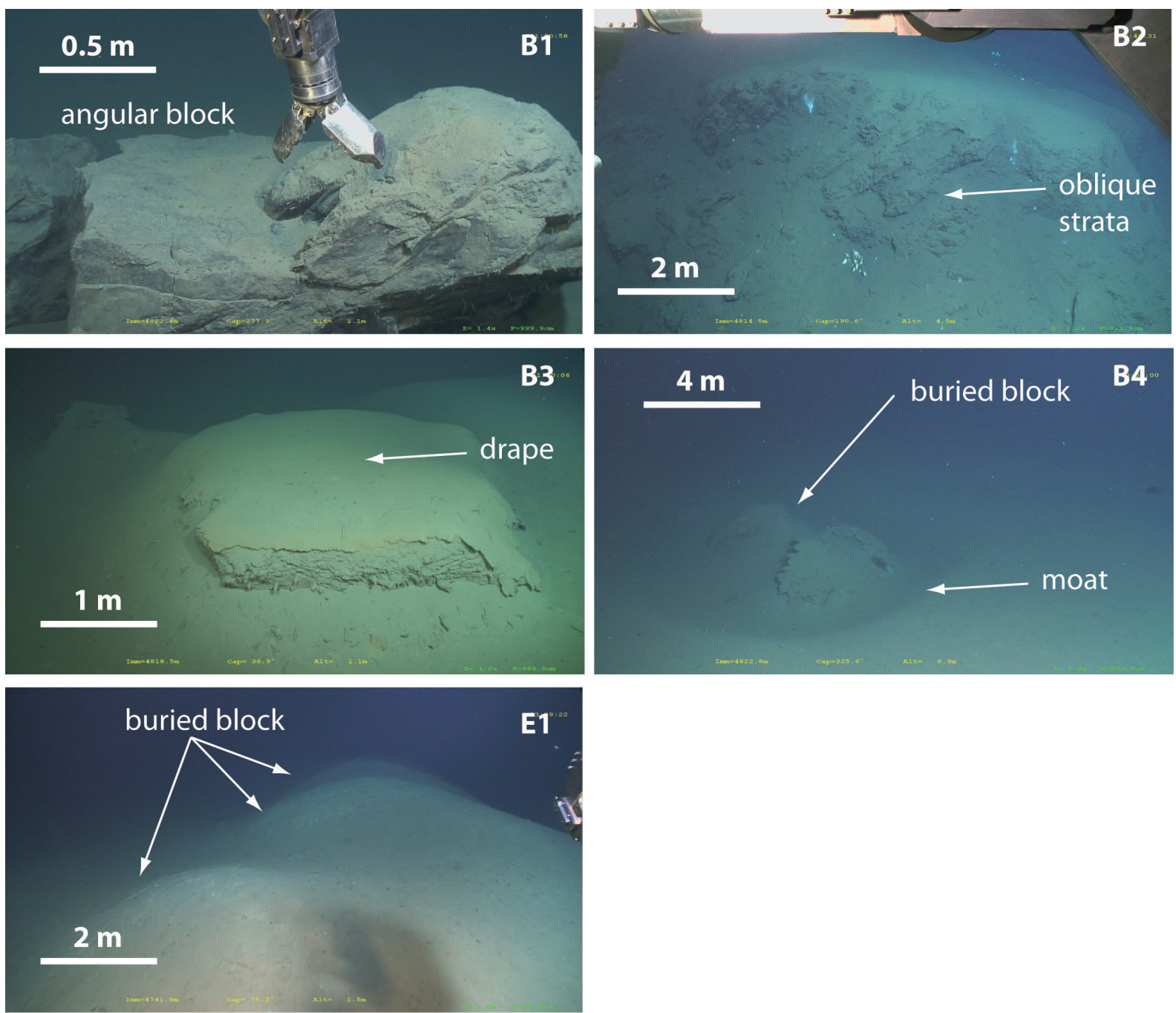

SM7: Seabed photos at sites B and E. (cf. Fig. 2). B1: Block with sharp angles; the ROV arm was able to break the block, showing that the sediment is soft. B2: Block showing oblique stratification that is interpreted as tilted fine-grained turbidites, (small white patches at base of the block: vesicomyd shells). B3: Block draped with sediment. B4:buried block surrounded by a moat, indicative of erosion. E1: Gently undulating relief corresponding to buried blocks at an abandoned lobe complex to the north of the study area (Site E). 

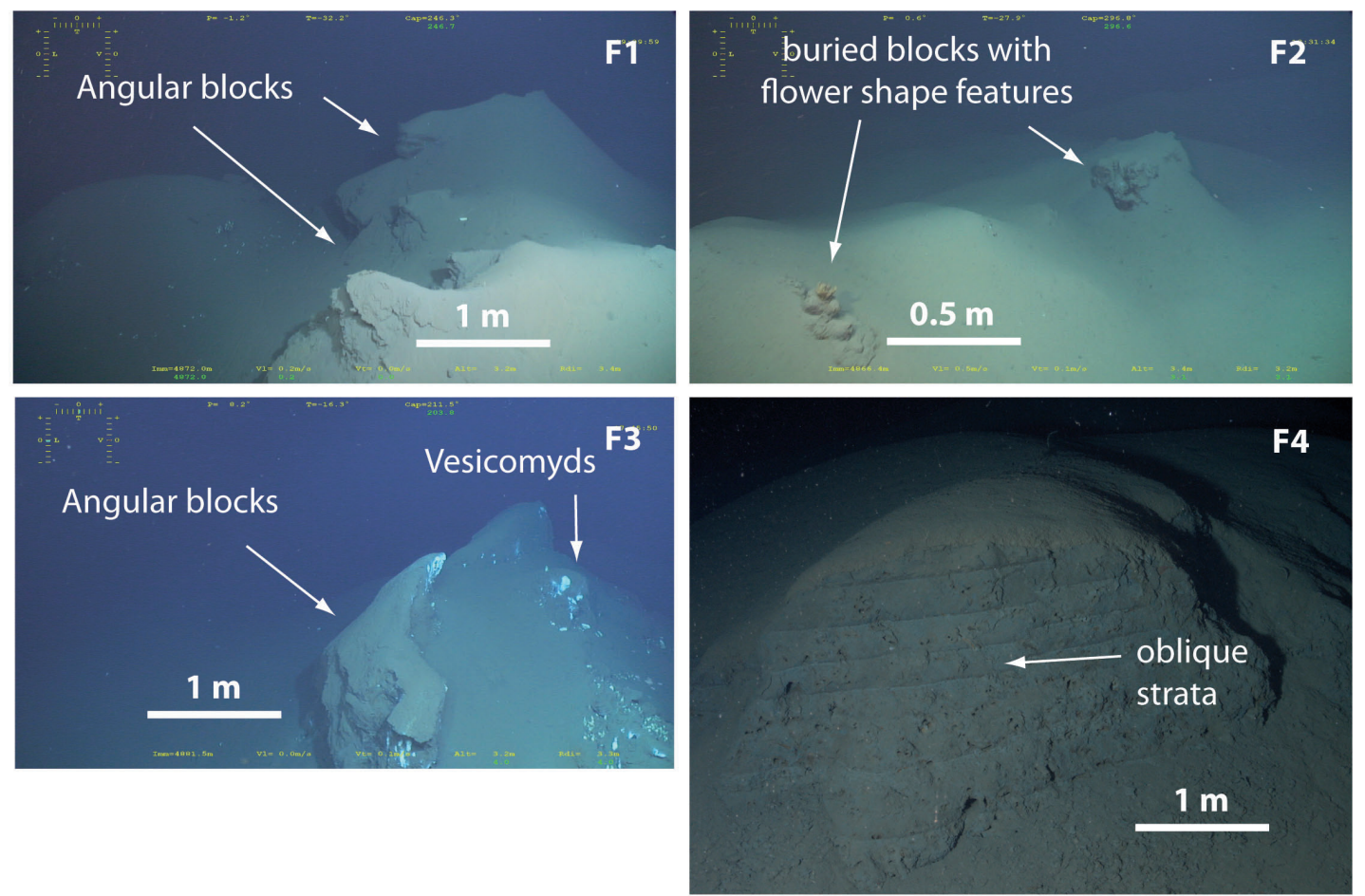

SM8: Seabed photos at sites F (cf. Fig. 9), along the western levees of the feeding channel. Location of images is shown in Fig. 9. F1 and F3: Buried block with still outcropping sharp angles. F2: Almost buried blocks; the flower-shaped structures on top of the block remain mysterious but may be the expression of fluid expulsion by dewatering. F4: Tilted block with slightly oblique stratification interpreted as fine-grained turbidites. 


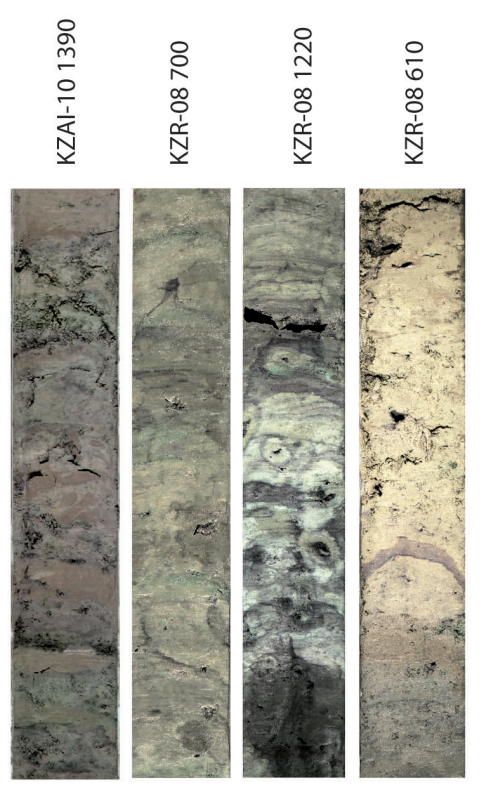

A: Siliceous or carbonate pelagic ooze

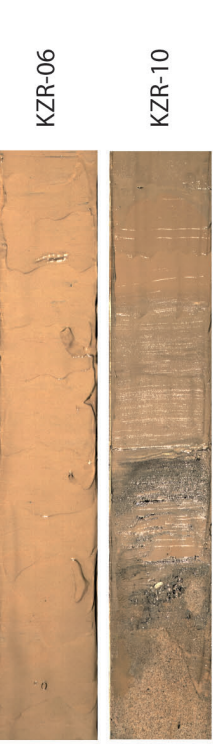

B:Structureless soft mud

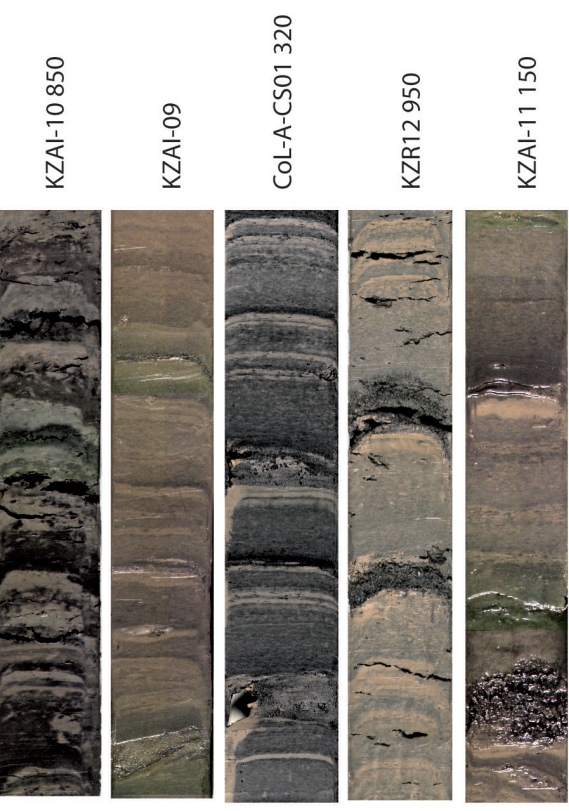

C: turbidite laminated mud and silt

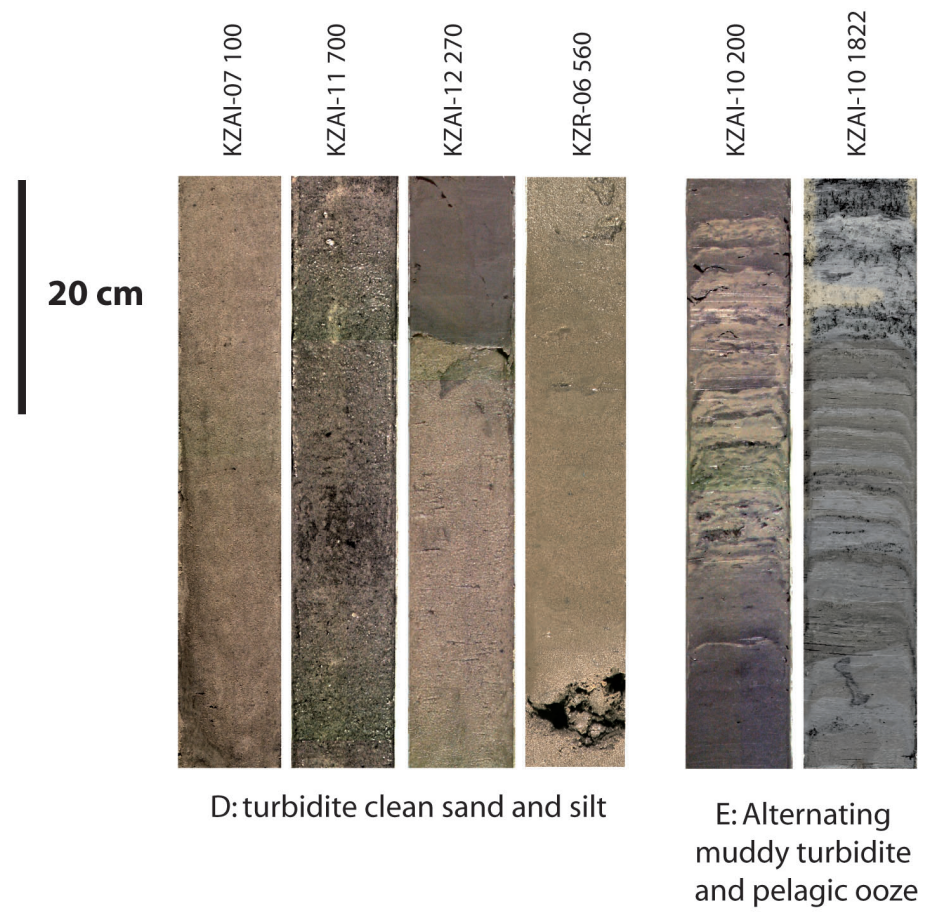

SM9: Photos summarizing the lithofacies recovered in the sediment cores at the Congo lobe complex. A: pelagic lithofacies composed of siliceous or carbonate pelagic ooze. B: turbidite structureless soft mud. C: turbidite laminated mud and silt. D: turbidite clean sand and silt. E: alternating muddy turbidites and pelagic ooze. The number after the core name indicates the depth in core (cm) of the top of the photos. 


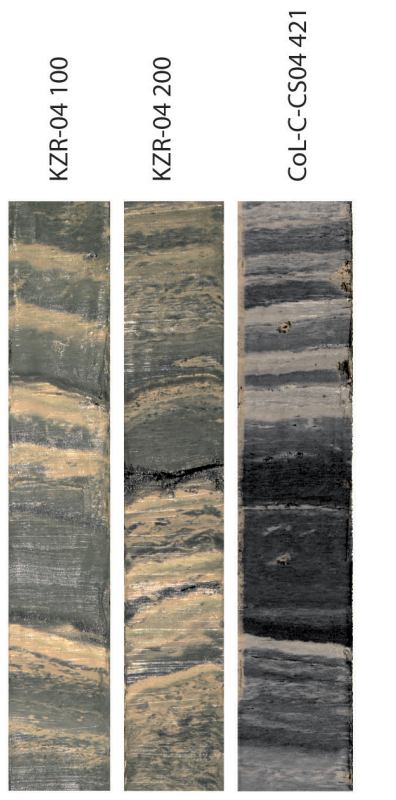

F: slightly deformed muddy turbidites

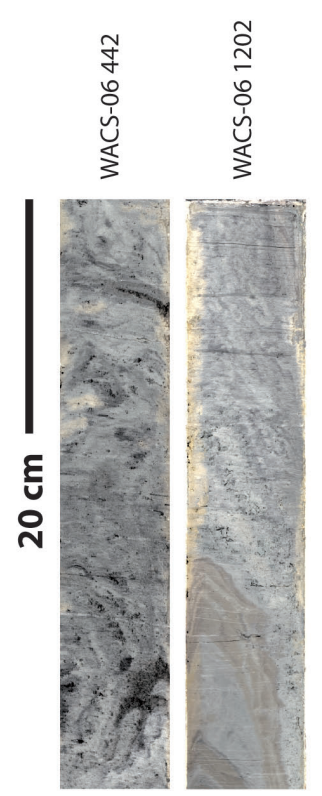

F: folded pelagic ooze

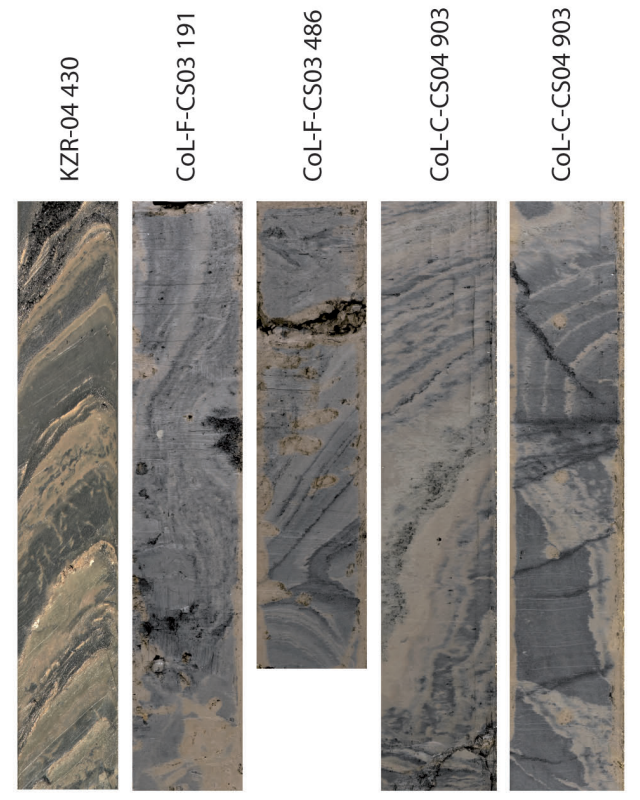

G: folded or faulted muddy turbidite

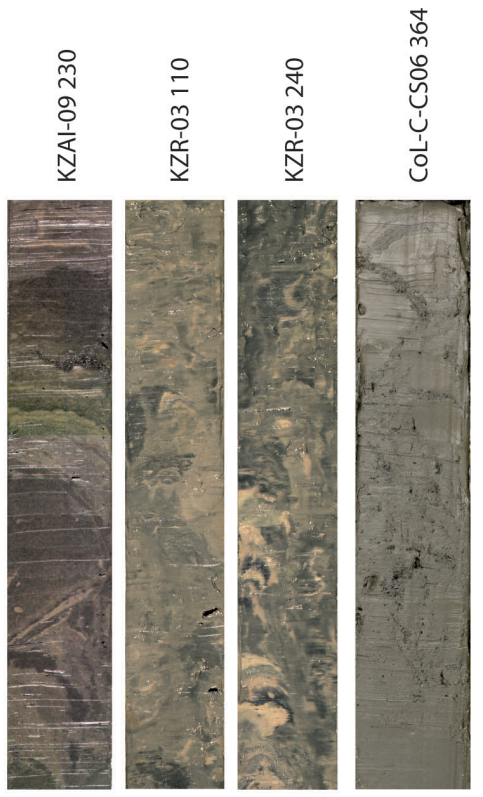

$\mathrm{H}$ : muddy conglomerate or debrite

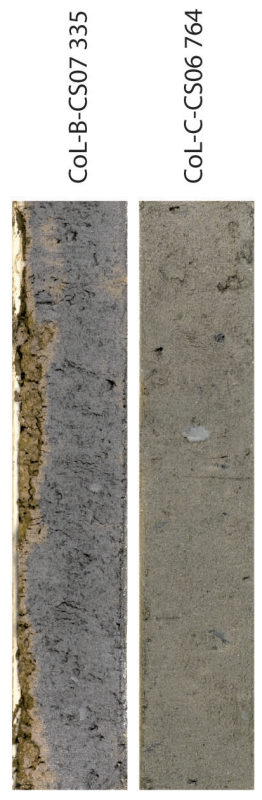

I: matrix dominant sandy debrite

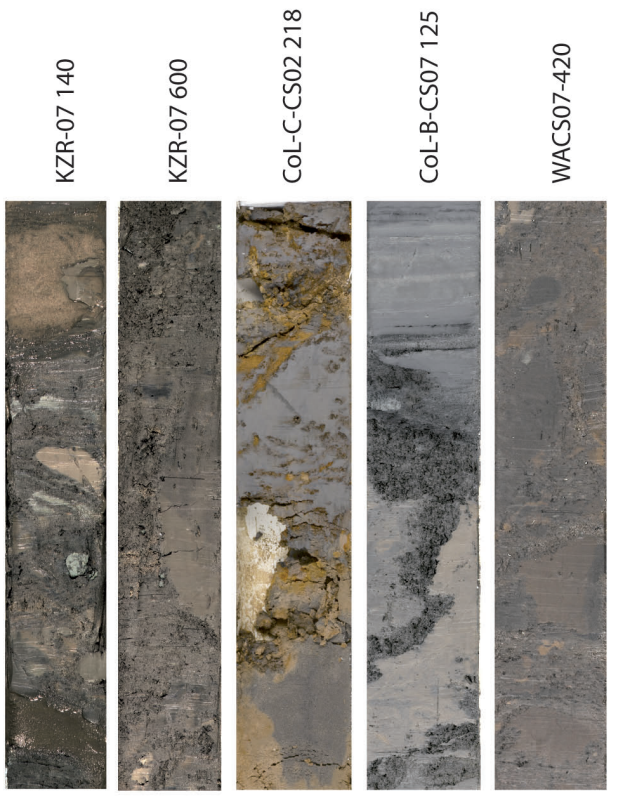

J: clast dominant sandy debrite with few small mudclasts

SM10: Photos summarizing the lithofacies recovered in the sediment cores at the Congo lobe complex. F and G: folded or faulted muddy turbidite. H: muddy conglomerate or debrite, J: matrix dominant sandy debrite with few small mudclasts. J: clast dominant sandy debrite. The number after the core name indicates the depth in core (cm) of the top of the photos. 